UNIVERSIDADE FEDERAL DE JUIZ DE FORA

FACULDADE DE LETRAS

PROGRAMA DE MESTRADO PROFISSIONAL EM LETRAS

Thamiris Alvim de Souza

O discurso citado na entrevista e na reportagem: uma abordagem de análise linguística em aulas do $8^{\circ}$ ano

Juiz de Fora 
THAMIRIS ALVIM DE SOUZA

O discurso citado na entrevista e na reportagem: uma abordagem de análise linguística em aulas do $8^{\circ}$ ano

Trabalho de conclusão apresentado ao Programa de Mestrado Profissional em Letras da Universidade Federal de Juiz de Fora como requisito parcial à obtenção do título de Mestre em Letras. Área de concentração: Estudos da Linguagem e Práticas Sociais

Orientador: Prof. ${ }^{a}$ Dr. ${ }^{a}$ Natália Sathler Sigiliano

Juiz de Fora 
Ficha catalográfica elaborada através do programa de geração automática da Biblioteca Universitária da UFJF,

com os dados fornecidos pelo(a) autor(a)

Souza, Thamiris Alvim de .

O discurso citado na entrevista e na reportagem : uma abordagem de análise linguística em aulas do $8^{\circ}$ ano / Thamiris Alvim de Souza. - 2021.

$156 \mathrm{f}$ : : il.

Orientadora: Natália Sathler Sigiliano

Dissertação (mestrado profissional) - Universidade Federal de Juiz de Fora, Faculdade de Letras. Programa de Pós-Graduação em Letras, 2021.

1. Ensino de Língua Portuguesa. 2. Análise Linguística. 3. Gêneros Textuais. 4. Discurso Citado. I. Sigiliano, Natália Sathler, orient. II. Título. 


\section{O discurso citado na entrevista e na reportagem: uma abordagem de análise linguística em aulas do $8^{\circ}$ ano}

\section{THAMIRIS ALVIM DE SOUZA}

Trabalho de Conclusão Final de Mestrado submetido ao Programa de Mestrado Profissional em Letras, da Universidade Federal de Juiz de Fora - UFJF, como parte dos requisitos necessários à obtenção do título de Mestre em Letras.

Aprovado em 21/05/2021

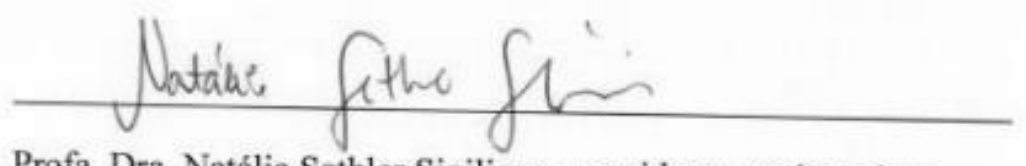

Profa. Dra. Natália Sathler Sigiliano - presidente e orientadora

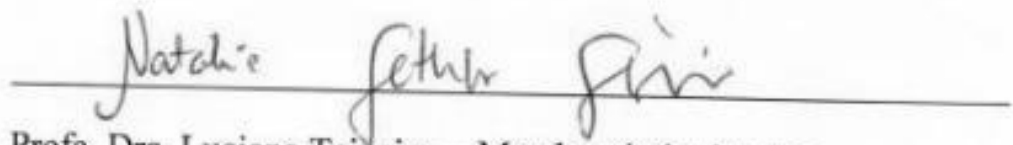

Profa. Dra. Luciana Teixeira - Membro titular interno

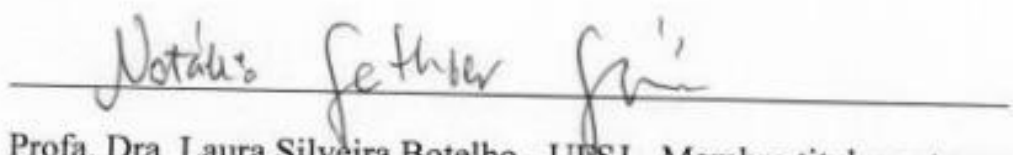

Profa. Dra Laura Silveira Botelho - UPSJ - Membro titular externo 


\section{AGRADECIMENTOS}

A Deus, que me honrou com a aprovação no Mestrado Profissional em Letras, que me abençoou com uma família que está sempre ao meu lado, que ouviu minhas preces para que tudo corresse bem ao longo desta trajetória e que me colocasse em boas mãos e que nunca me abandonou quando eu julgava não ser capaz.

À Agência de Fomento CAPES, que proporciona a nós, professores da rede pública de ensino, a formação profissional e o incentivo à pesquisa. $\mathrm{O}$ presente trabalho foi realizado com apoio da Coordenação de Aperfeiçoamento de Pessoal de Nível Superior - Brasil (CAPES) Código de Financiamento 001.

À Universidade Federal de Juiz de Fora e ao Programa de Mestrado Profissional em Letras, que acolhem tantos profissionais da educação, proporcionando formação crítica e reflexiva em relação à prática docente.

Ao corpo docente do Programa de Mestrado Profissional em Letras, por todo empenho e carinho na nossa formação.

À minha orientadora, Profa. Dra. Natália Sathler Sigiliano, por sua competência, atenção, incentivo e conselhos. Principalmente, por sua amizade e carinho, por nunca me abandonar durante este percurso e por me tornar uma profissional melhor e mais empenhada no meu propósito.

À Profa. Dra. Laura Silveira Botelho, que aceitou o convite para participar das minhas bancas de qualificação e defesa e por ampliar meus horizontes acerca da prática docente e da pesquisa.

À Profa. Dra. Luciana Teixeira, minha professora da graduação e do mestrado, que me honrou com sua presença na qualificação e na defesa, por contribuir para o enriquecimento da pesquisa.

Aos meus alunos, por seu carinho e alegria ao se voluntariarem como participantes da pesquisa, sendo fundamentais para a realização deste sonho e por me fazerem ter certeza do lugar onde quero estar. Felipe, Marcele, Maria Eduarda, Renan e Victória, obrigada por me ajudarem a alcançar esta conquista.

Aos meus amigos do curso, por estarmos juntos ao longo desta caminhada, contribuindo uns com os outros em todos os momentos, por terem trazido leveza a este processo, por todas as risadas e por toda amizade.

Aos meus amigos de toda vida, pelo companheirismo e dedicação. 
Aos meus pais, Esmeralda e Geraldo, que sempre acreditaram em mim e que nunca mediram esforços para que meus sonhos fossem realizados, por sempre me darem o suporte necessário para que eu pudesse caminhar sozinha, sem nunca soltarem minhas mãos.

Aos meus irmãos, Thainá e Júnior, pelo companheirismo, amizade, cumplicidade e carinho.

À minha sobrinha Clara, que chegou durante a reta final desta conquista e encheu meu coração de alegria e esperança.

A meu marido Leandro, por seu amor, amizade, companheirismo, generosidade, entendimento, incentivo e, principalmente, pela certeza de que esse dia chegaria. 


\section{RESUMO}

Esta dissertação apresenta uma proposta interventiva, desenvolvida em sala de aula de língua portuguesa, em uma turma de $8^{\circ}$ ano, com foco no uso do discurso citado (Authier-Revuz, 1990; Bakhtin, 1990; Benites, 2002; Castro, 2009; Garcia, 2009 e Silva e Barbosa, 2016) e no processo de retextualização (Marcuschi, 2001; Dell'Isola, 2007; Benfica, 2013). Tal proposta funda-se na perspectiva da Análise Linguística (Geraldi, 1984; Mendonça, 2006), na qual a prática analítica perpassa às de leitura, escrita e oralidade. Adota, ainda, o procedimento da pesquisa-ação (Thiollent, 2011) e os princípios da sequência didática (Schneuwly; Dolz, 2004; Costa-Hübes; Simioni, 2014). A proposta interventiva partiu do reconhecimento de dificuldades dos alunos quanto ao uso do discurso citado e ao conhecimento dos estudantes sobre o gênero reportagem e teve os objetivos de levar os alunos a (a) refletir, analisar e compreender a importância do uso do discurso citado para a construção dos gêneros textuais entrevista e reportagem, (b) utilizar o discurso citado de forma a contribuir para a produção de sentidos e propósitos do texto e identificar seus tipos, direto e indireto, no texto, além de (c) refletir sobre as operações necessárias para o processo de retextualização. Entendendo que a formação de cidadãos não ocorre apenas pelo domínio de desenvolvimento da linguagem que compete a escola, assume-se a importância do trabalho com a reflexão social no espaço das aulas de língua portuguesa. Nesse sentido, na intervenção proposta, a temática da inclusão de alunos com deficiência perpassou todo o projeto. $\mathrm{O}$ trabalho assume a hipótese de que a reflexão e o aprendizado sobre o uso do discurso citado e a retextualização de gêneros textuais, que exijam a alteração de pessoas do discurso, podem ocorrer de forma efetiva caso a abordagem de aspectos gramaticais seja realizada em contextos em que eles se fazem relevantes. Assim, durante toda a intervenção, os alunos foram guiados a ler e a produzir textos do campo jornalístico/midiático, os quais se revelam interessantes para o trabalho com o discurso citado. Ademais, acredita-se que relacionar tais questões linguísticas à temática da inclusão de pessoas portadoras de deficiência possa contribuir na sensibilização e conscientização dos alunos em relação à inclusão no espaço escolar. Na perspectiva da pesquisa-ação, houve constante análise das interações com os alunos e de suas produções para a criação da proposta interventiva, a qual pode ser mais bem conhecida por meio do Caderno Pedagógico, ao qual este texto se associa. Em termos de análise de cunho quantitativo, que motivou as escolhas dos módulos da sequência de atividades proposta no Caderno Pedagógico, foi realizada a avaliação das produções iniciais do gênero reportagem, feitas pelos estudantes. Nesta dissertação, é possível observar a análise das produções iniciais e finais dos estudantes, a qual revela que os alunos obtiveram ganhos 
relevantes quanto ao conhecimento do gênero e se apropriaram do emprego do discurso citado. Os resultados obtidos nessa pesquisa-ação apontam para a importância de relacionar o ensino do discurso citado aos gêneros textuais em que ele se faz relevante e de reconhecer e produzir diferentes gêneros textuais orais e escritos que envolvam situações sociais distintas para que haja desenvolvimento da reflexão e do uso da língua nas distintas situações. Os resultados também apontam para o aperfeiçoamento das operações de retextualização contempladas na intervenção. Além disso, a temática que perpassou grande parte das etapas da intervenção possibilitou o desenvolvimento da formação cidadã dos participantes e de sua criticidade quanto à inclusão de alunos com deficiência no espaço escolar, valorizando essa inserção e reconhecendo seu papel nesse processo.

Palavras-chave: Discurso citado. Reportagem. Retextualização. Inclusão. 


\begin{abstract}
This dissertation presents an intervention proposal developed in a Portuguese language classroom, in an 8th grade class, focusing on the use of the quoted speech (Authier-Revuz, 1990; Bakhtin, 1990; Benites, 2002; Castro, 2009; Garcia, 2009 and Silva and Barbosa, 2016) and in the retextualization process (Marcuschi, 2001; Dell'Isola, 2007; Benfica, 2013). This proposal is based on the perspective of Linguistic Analysis (Geraldi, 1984; Mendonça, 2006), in which the analytical practice goes beyond those of reading, writing and orality. It also adopts the action research procedure (Thiollent, 2011) and the principles of the didactic sequence (Schneuwly and Dolz, 2004; Costa-Hübes and Simioni, 2014). The interventional proposal started from the recognition of students difficulties regarding the use of the quoted speech and the students' knowledge about the reportage genre and had the objectives of leading students to (a) reflect, analyze and understand the importance of using the quoted speech for the construction of textual genres interview and reportage, (b) use it in a way to contribute to the production of meanings and purposes of the text and identify its types, direct and indirect, in the text, in addition to (c) reflect on the necessary operations in the retextualization process. Understanding that the formation of citizens does not occur only through the development of language, the importance of working with social reflection in the space of Portuguese language classes is assumed. In this sense, in the proposed intervention, the theme of including students with disabilities permeated the entire project. The work assumes that reflection and learning can occur effectively if the approach to grammatical aspects is carried out in contexts where they are relevant. Thus, during the entire intervention, students were guided to read and produce texts from the journalistic / media field, which prove to be interesting for working with the quoted speech. From the perspective of action research, there was a constant analysis of interactions with students and their productions for the creation of the intervention proposal, which can be better known by the Pedagogical Notebook, to which this text is associated. In terms of quantitative analysis, which motivated the choice of modules for the proposed sequence of activities in the pedagogical notebook, the students' initial production of the reportage genre was carried out. In this dissertation, it is possible to observe the analysis of the students' initial and final productions, which reveals that the students obtained relevant gains in terms of gender knowledge and appropriated the use of the quoted speech. The results obtained in this action research point to the importance of relating the teaching of the quoted speech to the textual genres in which it is relevant and of recognizing and producing different oral and written textual genres that involve different social situations
\end{abstract}


so that there is development of reflection and the use of language in different situations. The results also point to the improvement of the retextualization operations contemplated in the intervention. In addition, the theme that permeated a large part of the intervention stages enabled the development of the citizens' education of the participants and their criticality regarding the inclusion of students with disabilities in the school space, valuing this insertion and recognizing their role in this process.

Keywords: Quoted speech. Reportage. Retextualization. Inclusion. 


\section{LISTA DE ILUSTRAÇÕES}

Figura $1-$ Modelo de Sequência Didática por Schneuwly e Dolz 36

Figura 2 - Modelo de Sequência Didática por Costa-Hübes e Simioni $\quad 37$

Figura 3 - Aspectos envolvidos na retextualização por Marcuschi $\quad 50$

Figura 4 - Operações de retextualização 51

Quadro 1 - Técnicas no tratamento dos turnos 53-54

Quadro 2 - As características dos tipos de discurso na Gramática Normativa $\quad 57$

$\begin{array}{ll}\text { Quadro } 3 \text { - Etapas da Intervenção } & 70\end{array}$

Quadro 4 - Trecho de produção inicial - exemplo 1 (aluno 17) 88

Quadro 5 - Trecho de produção inicial - exemplo 2 (aluno 19) 88

Quadro 6 - Trecho de produção inicial - exemplo 3 (aluno 32) 89

Quadro 7 - Trecho de produção inicial - exemplo 4 (aluno 26) 89

Quadro 8 - Trecho de produção inicial - exemplo 5 (aluno 17) 89

Quadro 9 - Trecho de produção inicial - exemplo 6 (aluno 28) 90

Quadro 10 - Trecho de produção inicial - exemplo 7 (aluno 16) 90

Quadro 11 - Trecho de produção inicial - exemplo 8 (aluno 17) 90

Quadro 12 - Trecho de produção inicial - exemplo 9 (aluno 10) 91

Quadro 13 - Trecho de produção inicial - exemplo 10 (aluno 28) 91

Quadro 14 - Trecho de produção inicial - exemplo 11 (aluno 31) 91

Quadro 15 - Trecho de produção inicial - exemplo 12 (aluno 32) 92

Quadro 16 - Trecho de produção inicial - exemplo 13 (aluno 33) 92

Quadro 17 - Trecho de produção inicial - exemplo 14 (aluno 1) 92

Gráfico 1 - Análise quantitativa/percentual da produção inicial 94

Quadro 18 - Questionário - Inclusão de pessoas com deficiência: vivências, pensamentos e opiniões $\quad 97-98$

Quadro 19 - Alguns passos para a realização e publicação de uma $\begin{array}{ll}\text { Entrevista } & 102\end{array}$

Quadro 20 - Semelhanças e diferenças entre as entrevistas escrita e Oral 104

Quadro 21 - Características do discurso direto e do discurso indireto 110

Quadro 22 - Produção final - exemplo 15 (aluno 3) 112-113

Quadro 23 - Trecho de produção final - exemplo 16 (aluno 3) 115

Quadro 24 - Produção final - exemplo 17 (aluno 5) 116-117

Quadro 25 - Trecho de produção final - exemplo 18 (aluno 5) 118

Figura $5-$ Trecho de produção final - exemplo 19 (aluno 1) 120

Quadro 26 - Trecho de produção inicial - exemplo 20 (aluno 2) 121

Quadro 27 - Trecho de produção final - exemplo 21 (aluno 2) 122

Quadro 28 - Trecho de produção final - exemplo 22 (aluno 1) 123

Quadro 29 - Trecho de produção inicial - exemplo 23 (aluno 1) 124

Quadro 30 - Trecho de produção final - exemplo 24 (aluno 1) 124

Quadro 31 - Trecho de produção inicial - exemplo 25 (aluno 2) 125

Quadro 32 - Trecho de produção final - exemplo 26 (aluno 2) 126 


\section{LISTA DE TABELAS}

Tabela 1 - Aspectos analisados na produção inicial....................................... 83

Tabela 2 - Análise quantitativa/percentual das produções............................ 87 


\section{SUMÁRIO}

INTRODUÇÃ

2.1 O PAPEL DA ANÁLISE LINGUÍSTICA NO ENSINO DE LÍNGUA MATERNA

2.2 GÊNEROS E SEU PAPEL CENTRAL NO ENSINO DA LÍNGUA 32

2.2.1 A Sequência Didática no ensino de Língua Portuguesa 35

2.2.2 Os gêneros textuais do campo jornalístico/midiático 38

2.2.2.1 O gênero textual entrevista e a retextualização como instrumento para o ensino de LP 39

2.2.2.2 O gênero reportagem como ferramenta para o ensino de LP ..................... 41

2.2.3 A relação entre multimodalidade e gêneros textuais ................................. 42

2.3 O PROCESSO DE RETEXTUALIZAÇÃO NO ENSINO DE LP ............... 44

2.3.1 A relação entre oralidade e escrita ......................................................... 45

2.3.2 A retextualização em sala de aula ............................................................ 46

2.4 O DISCURSO CITADO NA CONSTRUÇÃO DO GÊNERO TEXTUAL

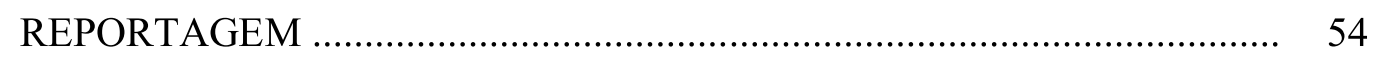

2.5 A INCLUSÃO ESCOLAR: REFLEXÃO E SENSIBILIZAÇÃO ................. 59

3 A METODOLOGIA DA PESQUISA-AÇÃO _...................................... 63

3.1 LÓCUS DA PESQUISA E SUJEITOS ENVOLVIDOS .............................. 67

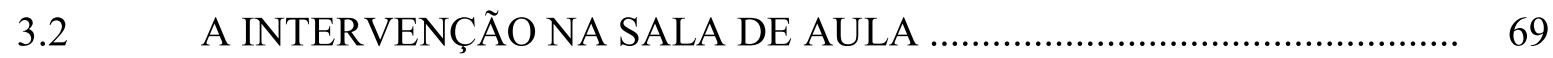

3.3 INSTRUMENTOS DE ANÁLISE PARA COMPOSIÇÃO DOS MÓDULOS DA INTERVENÇÃO E PARA A PESQUISA .......................... 73

4 DESCRIÇÃO E ANÁLISE DA INTERVENÇÃO EM SALA DE

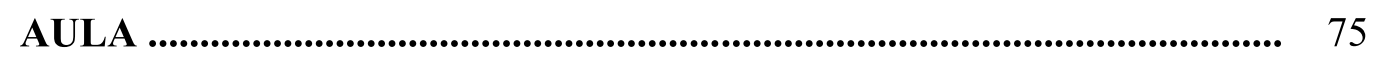

4.1 PRÉ-INTERVENÇÃO: CONHECENDO A TURMA …............................... 75

4.2 DESCRIÇÃO E ANÁLISE DAS ETAPAS DA INTERVENÇÃO ............... 79

4.2.1 Primeira Etapa: Observando os gêneros textuais entrevista e reportagem ............................................................................................. 79

4.2.1.1 Descrição e análise dos textos produzidos na primeira etapa .................. 82

4.2.2 Segunda etapa: Ambientação e primeiras reflexões sobre a temática da inclusão escolar ........................................................................................ 95 
4.2.3 Terceira etapa: Gênero textual entrevista - um passeio entre modalidades

4.2.4 Quarta etapa: Gênero textual reportagem

4.2.5 Quinta etapa: $O$ discurso citado no gênero textual reportagem na modalidade escrita ......................................................................................... 108

4.2.6 Sexta etapa: Colocando os conhecimentos em prática (Produção Final) 111

ANEXO A - Roteiro de perguntas para a entrevista

ANEXO B - Entrevista escrita (aluno 1)

ANEXO C - Entrevista escrita (aluno 2)

ANEXO D - Reportagem (aluno 1)

ANEXO E - Reportagem (aluno 2)

ANEXO F - Produção Inicial (aluno 1) 148

ANEXO G - Produção Inicial (aluno 2) 150

ANEXO H - Produção Final (aluno 1) 152

ANEXO I - Produção Final (aluno 2) 


\section{INTRODUÇÃO}

Sabe-se que, atualmente, a educação brasileira enfrenta muitos problemas. Dados alarmantes são frequentemente noticiados, apontando para deficiências no ensino das escolas de educação básica. A última pesquisa feita pelo IBGE (Instituto Brasileiro de Geografia e Estatística), em 2018, aponta que o Brasil ainda possui 11,3 milhões de analfabetos entre a população de 15 anos ou mais. Além disso, avaliações nacionais, como o Sistema Nacional de Avaliação da Educação Básica (Saeb), de 2017, mostram que 60,51\% dos alunos terminam o $9^{\circ}$ ano no nível considerado insuficiente, indicando que não apreenderam o mínimo - julgado como necessário com base nas escalas utilizadas - quanto aos conhecimentos de português. Além disso, os objetivos traçados no Plano Nacional de Educação (PNE) não têm sido alcançados, já que a taxa de $93,5 \%$ de alfabetizados, proposta para 2015, ainda não foi cumprida ou superada. Todo esse cenário contribui para que os créditos negativos desses dados sejam atribuídos, na grande maioria das vezes, às aulas de língua portuguesa.

Há anos, documentos norteadores, como os Parâmetros Curriculares Nacionais (PCN) e, mais recentemente, a Base Nacional Comum Curricular (BNCC), enfocam a importância do ensino pautado em uma visão sociointeracionista de linguagem. Tal enfoque pressupõe a necessidade de abordagem de situações de interação, o que vem sendo feito por meio do estudo de diferentes gêneros textuais, perpassando todos os eixos de ensino (leitura, escrita, oralidade e análise linguística), para que se amplie o conhecimento de uso da língua nas mais distintas esferas. Nesse contexto, expandir o conhecimento de uso dos gêneros textuais é importante para mostrar ao aluno o real propósito da língua, que é o seu uso como instrumento de interação social.

A relevância do estudo a partir dos gêneros se justifica na medida em que se comprova o que já vem sendo dito e estudado desde 1980, ou seja, que o texto deve ser tomado como centro do ensino da língua. Na apresentação da tradução da obra "Gêneros orais e escritos na escola", Rojo afirma:

Não é de hoje que circula e é aceita, no Brasil, a ideia de que o texto - seja como material concreto sobre o qual se exerce o conjunto dos domínios de aprendizagem, sobretudo leitura e produção de textos, seja como objeto de ensino propriamente dito - é a base do ensino aprendizagem de língua portuguesa no ensino fundamental (SCHNEUWLY; DOLZ, 2004, p.7).

A discussão sobre a forma como a língua portuguesa (LP) tem sido ensinada nas escolas é bastante frequente no meio acadêmico. Porém, da parte dos docentes de LP, um grande 
desafio enfrentado é o de atrelar avanços teóricos e metodológicos à prática de ensino em sala de aula. Dessa forma, o Mestrado Profissional em Letras (PROFLETRAS) busca formar profissionais que estreitam essa relação, pois, ao mesmo tempo em que se aprofundam nas teorias mais recentes quanto ao ensino da língua, elaboram produtos pedagógicos e intervenções em sala de aula que revelam práticas condizentes com os estudos realizados, e é nesse contexto que este texto se constitui ${ }^{1}$.

A tarefa de se ensinar língua portuguesa envolve múltiplas dimensões. Além dos diversos aspectos associados ao ensino de LP, neste trabalho haverá um foco especial no que tange a um dos eixos de ensino: análise linguística, o qual perpassa os demais. Diversos linguistas, como Antunes (2014), Mendonça (2006), Geraldi (2012 [1984]), Franchi (2006) e outros apontam que estudar a gramática usando o texto como um mero acessório não vinha surtindo efeito positivo no ensino da língua. Portanto, a perspectiva de que o texto deve ser o centro do ensino é fundamental para uma prática efetiva. Além disso, como a atividade humana está vinculada ao uso da língua, os gêneros textuais orais e escritos vão demonstrar as ações sociais, portanto, eles devem ser apresentados aos alunos de forma que reflitam seu cotidiano, visando à interação além do ambiente escolar. Conforme aponta a BNCC (BRASIL, 2017), é no trabalho com os gêneros textuais, por meio dos eixos de leitura, escrita e oralidade, que o eixo da análise linguística ganha força para a construção do conhecimento acerca do funcionamento da língua.

Ao se adotar a perspectiva de abordagem de LP de forma contextualizada, entende-se que outras tarefas podem auxiliar no sentido de alcançar o maior engajamento do aluno. Assim, para promover um ensino de LP mais efetivo, é fundamental que o professor conheça o cotidiano de seus alunos, ou seja, ele precisa tornar-se um pesquisador da realidade que os cerca, dos seus interesses e necessidades. Nesse sentido, “o papel do pesquisador deve ser o de oferecer subsídios que propiciem a participação dos atores sociais envolvidos em todas as etapas e assegurar o rigor metodológico, o qual favorecerá o cumprimento dos objetivos propostos" (TOLEDO; JACOBI, 2013, p.160).

A metodologia da pesquisa-ação (THIOLLENT, 2011) contribui para o reconhecimento da realidade em que o professor se encontra. Por meio da pesquisa-ação, o docente, que é atuante no próprio ambiente investigado, torna-se parte da pesquisa a qual ele

\footnotetext{
${ }^{1}$ Esta pesquisa foi realizada no âmbito do Mestrado Profissional em Letras da UFJF e faz parte do projeto de pesquisa intitulado Gêneros, tipologias textuais e análise linguística: constituição de recursos didáticos para o trabalho contextualizado dos conhecimentos linguísticos em uma abordagem orientada pelos gêneros textuais, coordenado pela professora Dra. Natália Sathler Sigiliano.
} 
mesmo realiza. Através dela, o professor consegue investigar e diagnosticar problemas enfrentados pelos estudantes nos processos de ensino-aprendizagem. Com isso, no caso do ensino de LP, pode elaborar estratégias para melhorar o ensino e a aprendizagem dos alunos, proporcionando um cenário mais produtivo tanto para a reflexão sobre o uso e funcionamento da língua, quanto para a construção de conhecimentos sobre a língua. De acordo com o pensamento adotado até aqui, este trabalho tem a intenção de proporcionar ensino de língua portuguesa através de práticas coerentes com o cenário pesquisado e com os problemas enfrentados pelos alunos. Como professora pesquisadora, meu primeiro contato com a turma, na qual foi realizada a intervenção que será apresentada neste texto, foi no ano letivo de 2020, sendo ela uma turma de $8^{\circ}$ ano do Ensino Fundamental II da Escola Estadual Engenheiro Henrique Dumont, localizada no município de Santos Dumont, na região da Zona da Mata de Minas Gerais. A turma, inicialmente, era composta por 33 alunos, todos na faixa etária de escolaridade correta. Destes, três eram alunos de educação especial e inclusiva, ou seja, alunos que, embora frequentem as salas de aula de ensino regular, precisam de atendimento especializado por portarem algum tipo de deficiência. Como o tempo de contato com a turma foi curto, por questão da suspensão das aulas em março de 2020 devido à pandemia de Covid19, as informações que tenho são insuficientes sobre os casos e sobre a realidade desses alunos, principalmente, por não terem laudos que dão direito ao professor bidocente (professor de apoio). No entanto, o conhecimento desse cenário, no qual a turma se inseria, é essencial para o entendimento da temática que perpassa a intervenção proposta e as circunstâncias em que tal aplicação se deu.

Em maio de 2020, o Governo de Minas Gerais autorizou o retorno das atividades escolares referentes ao ano letivo de 2020 através do Regime Especial de Atividades Não Presenciais (REANP) e o fez através de algumas ferramentas, como o Programa "Se Liga na Educação", com videoaulas disponibilizadas no Canal Rede Minas e TV Assembleia, o Plano de Estudos Tutorado (PET) e do aplicativo Conexão Escola. Ao professor, coube a tarefa de realizar a tutoria de seus alunos através do chat no aplicativo Conexão Escola e de outras redes sociais não institucionais, como o WhatsApp, a fim de ajudá-los na realização das atividades propostas nos PET. Dessa forma, o contato entre professor e aluno ficou reduzido a mensagens de apoio, auxílio e motivação. Com o retorno das aulas de forma remota, a escola onde trabalho decidiu que os alunos com deficiência seriam atendidos pelos professores de apoio/AEE (Atendimento Educacional Especializado) e não pelos professores regentes. Assim, o contato com esses alunos não foi possível, visto que não foram incluídos nos grupos de WhatsApp de suas respectivas turmas, essa interação com eles foi limitada ao professor de apoio. Dessa 
forma, não tive mais contato com esses alunos durante o período do ano letivo em que se manteve o ensino remoto.

Entretanto, torna-se crucial explicar que, desde o primeiro dia do ano letivo de 2020, observei cuidadosamente a turma, buscando formas de conhecer melhor os alunos e suas dificuldades, com intuito de traçar um projeto interventivo que fosse interessante, tendo em vista as reais necessidades daquele grupo de estudantes. Além disso, o contato com professores que já lecionaram na turma e com as equipes pedagógica e gestora foram importantes para entender a realidade que cerca os discentes, facilitando tal reconhecimento. O tempo de contato presencial foi curto, mas suficiente para que alguns indícios dados pela turma contribuíssem para a produção da etapa diagnóstica e sua aplicação, tornando possível algumas análises e hipóteses para a elaboração da intervenção.

Algumas hipóteses puderam ser levantadas através das dificuldades observadas na turma, sendo a retextualização de um gênero para outro e entre modalidades oral e escrita, a que mais me chamou a atenção. Essa observação foi feita através de uma roda de conversa para levantar os assuntos sobre os quais os alunos gostariam de trabalhar nas aulas de LP. Após tal interação, os alunos, em grupos, teriam que elaborar um parágrafo que justificasse a escolha dos temas elencados. Porém, nenhum grupo realizou, de forma adequada, o comando dado, visto que entregaram apenas listas de preferências com poucas justificativas ou mesmo nenhuma.

Com a aplicação e resultado dessa atividade, elaborei a sequência pedagógica que precedeu a chamada de produção inicial (produção diagnóstica) e observei que os alunos, muitas vezes de forma fiel, apenas reproduziam as informações de um texto a outro, não fazendo as adequações necessárias relacionadas ao gênero. Dessa forma, não se preocupavam com o modo como a retextualização entre gêneros textuais é feita ou com a forma como se referiam ou transmitiam o discurso de outra pessoa em um texto. Em uma análise prévia das produções dos alunos, destacaram-se alguns problemas gramaticais, como a pontuação, o uso dos verbos dicendi e de elocução e das pessoas do discurso, e, consequentemente, do discurso citado.

Além disso, pude perceber que os alunos de educação especial e inclusiva ficavam isolados nas atividades que envolvem a formação de grupos, ou não eram incentivados a participar em momentos que envolvem a turma como um todo, como por exemplo, na roda de conversa. Essa análise e a compreensão de que a disciplina de ensino de língua não se restringe ao ensino de conteúdos guiaram a uma escolha temática que perpassou a seleção dos textos da intervenção e as discussões durante as aulas. Dessa forma, a intervenção que será proposta explora a importância da socialização e integração de pessoas portadoras de necessidades 
especiais em todo e qualquer espaço de interação, principalmente do aluno com deficiência no espaço escolar.

A partir da observação e análise da produção inicial, reforçou-se a hipótese inicial de que um trabalho de reflexão sobre o uso do discurso citado e a retextualização de gêneros textuais - que exija a alteração de pessoas do discurso - pode auxiliar na aprendizagem de conteúdos gramaticais associados a essa ação, incentivando os alunos no reconhecimento das categorias relacionadas ao discurso citado e da importância delas para os gêneros em questão. Além disso, acredita-se que relacionar tais questões linguísticas à temática da inclusão de pessoas portadoras de necessidades especiais ajudará na sensibilização e na conscientização dos alunos em relação aos alunos com deficiência no espaço escolar.

Como já mencionado anteriormente, as aulas nas escolas estaduais de Minas Gerais aconteceram de forma remota durante grande parte do ano letivo de 2020, ano em que a aplicação desta proposta foi realizada. Com isso, muito se perdeu não só em relação à aplicação da intervenção inicial, apresentada em minha qualificação de mestrado, mas também em relação ao meu objetivo inicial, qual seja, a contribuição para o processo de ensino-aprendizagem dos alunos com deficiência e sua maior integração nas atividades escolares. Sem o ensino presencial, a intervenção, da forma como havia sido planejada, tornou-se inviável, uma vez que não havia nenhum contato com os alunos com deficiência da turma escolhida para a aplicação. Além disso, havia pouca autonomia e autoria envolvidas no trabalho do professor nesse cenário de pandemia brevemente relatado, uma vez que o Estado instituiu a realização do PET para computar a carga horária dos alunos, ou seja, as aulas e os materiais aplicados foram criados e disponibilizados pelo governo.

Nesse cenário, houve, por meio do Conselho Gestor da Coordenação Nacional do Programa de Mestrado Profissional em Letras (PROFLETRAS), através da Resolução ${ }^{\circ}$ 003/2020, em 02 de junho de 2020, autorização para que os trabalhos desenvolvidos no âmbito do PROFLETRAS, para as turmas ingressantes em 2019, passassem a ter caráter tão somente propositivo e, não necessariamente interventivo. No entanto, foi de meu desejo aplicar a intervenção, ainda que de forma distinta daquela inicialmente planejada. Dessa forma, como não havia encontros síncronos de aula regulamentados pelo estado de Minas, a intervenção foi proposta aos alunos como um convite a participarem, respeitando sua escolha de aceitar ou não e considerando que havia alunos sem possibilidade de participar remotamente.

O convite para as aulas síncronas e realização de atividades extras foi feito por mim aos alunos pelo grupo de WhatsApp da turma e também de forma individual, explicando o caráter da intervenção como uma carga horária extra durante o ano letivo de 2020. Felizmente, 
mesmo com o contexto da suspensão das aulas no formato presencial, 5 alunos aceitaram o convite para participar da intervenção, e, embora não fosse o cenário idealizado incialmente, a aplicação da intervenção foi fundamental para a observação e mudança da minha prática em sala de aula, para a análise e comparação dos resultados obtidos e, principalmente, para a valorização dos alunos que se empenharam em participar. Dessa forma, a intervenção foi iniciada em 21 de setembro de 2020, fora do REANP, com 5 alunos do oitavo ano do Ensino Fundamental, com aulas através da plataforma Zoom e com atividades desenvolvidas pelo WhatsApp, Gmail, Google Formulário, Google Drive e Google Sala de Aula.

A proposta interventiva foi redesenhada e elaborada, tendo como foco a mudança do gênero textual entrevista oral para o gênero textual reportagem escrita, principalmente no que se refere ao uso adequado do discurso citado no segundo gênero citado. As atividades que compuseram a intervenção foram baseadas, majoritariamente, em entrevistas e reportagens selecionadas pela professora pesquisadora, em práticas de análise linguística e em produções orais e escritas dos alunos. Alguns outros gêneros textuais, como videoanimação e HQ's, foram utilizados com enfoque na ambientação da temática de pessoas portadoras de necessidades especiais e sua inclusão nos espaços de interação social.

Conforme já mencionado, a metodologia da pesquisa-ação aponta para a necessidade de o professor assumir o papel de pesquisador da sua realidade. Colocando-me nessa posição, pude perceber a forma como os alunos especiais são acolhidos socialmente pelos colegas, porém permanecem distantes das práticas de ensino de LP, e como esse fato é reflexo do que a sociedade representa para essas crianças, visto que, mesmo com grandes avanços no que se refere à inclusão dos portadores de necessidades especiais, ainda é muito comum a prática, ainda que involuntária, da exclusão dessas pessoas.

Tal olhar de professora pesquisadora fez com que a visão do meu papel como educadora tomasse uma dimensão ainda maior. Percebi que fazer diferente e, como consequência, fazer a diferença vai muito além das distintas estratégias nos processos de ensino e de aprendizagem de LP. Observando a realidade da qual faço parte, a inclusão das pessoas portadoras de necessidades especiais, principalmente no ambiente escolar é algo que me causa inquietação. Na escola onde trabalho, os alunos de educação especial são sempre bem recebidos e respeitados por todos, não vejo problema no que diz respeito à receptividade desses em relação a eles. Porém, dentro de sala de aula, não há integração desses discentes com o ambiente escolar, como já dito anteriormente, pois ficam à mercê de o professor tentar encaixá-los em algum grupo. Caso isso não seja feito, muitas vezes, não participam das atividades propostas. Como já dito anteriormente, essa realidade é reflexo do que acontece também em outros contextos, 
além do escolar. Logo, um dos objetivos da intervenção é justamente a sensibilização e conscientização dos alunos sobre a inclusão de pessoas com deficiência, principalmente, no espaço escolar, o que é realizado, na proposta que será apresentada, por meio de provocações da abordagem dessa temática em entrevistas e reportagens.

Essa é uma realidade que, atrelada às questões linguísticas a que este trabalho se propôs, intento modificar, buscando formas por meio das quais toda a turma possa apropriar-se de conhecimentos concernentes aos gêneros textuais, à retextualização e a aspectos gramaticais que nortearam a proposta interventiva e tornando maior a conscientização da inclusão das pessoas com deficiência. O objetivo desta temática é promover a reflexão sobre a inclusão e integração de pessoas portadoras de necessidades especiais nos diferentes contextos sociais, principalmente, ao ambiente escolar. Portanto, o objetivo desta pesquisa é promover e analisar práticas mais reflexivas de ensino de língua portuguesa, visando à formação de alunos mais conscientes sobre o uso e funcionamento da própria língua, principalmente no que diz respeito a um trabalho voltado para o ensino e reflexão sobre os gêneros reportagem e entrevista, o processo de retextualização desses gêneros e sobre a relevância do discurso citado nesses gêneros e nesse processo.

Para o trabalho com o gênero textual entrevista e reportagem, contamos com a colaboração de profissionais e membros da comunidade escolar que puderam contribuir com suas experiências acerca da inclusão escolar, para ajudar os alunos a refletir de forma mais efetiva sobre o assunto, de forma atrelada à realidade local. Os alunos entrevistaram colegas, professores, pedagogos e psicopedagogos, estreitando a relação não só do professor regente, mas também dos alunos com o tema, compartilhando diferentes perspectivas e opiniões sobre o assunto abordado, o que, além de viabilizar a discussão do tema, permitiu o trabalho com o gênero textual entrevista nas modalidades oral e escrita, além do seu uso para a construção do gênero textual reportagem.

Nesse sentido, a intervenção proposta neste trabalho coloca o gênero textual no papel central do ensino de língua portuguesa, em especial a entrevista e a reportagem, que são os gêneros que irão direcionar o trabalho da análise linguística e a abordagem temática da educação especial e inclusiva. A Análise Linguística (GERALDI, 1984 e MENDONÇA, 2006), a Gramática Contextualizada (ANTUNES, 2014) e o uso dos Gêneros Textuais para o ensino da língua (MARCUSCHI, 2008 e 2011 e SCHNEUWLY; DOLZ, 2004), o uso dos gêneros textuais do campo jornalístico/midiático (BALTAR, 2004; SCHNEUWLY; DOLZ, 2004; HOFFNAGEL, 2010 e SILVA, 2010), a multimodalidade no estudo dos gêneros textuais ( KRESS; LEEUWEN, 1996; KRESS, 2003 e 2010; CAVALCANTE, 2012 e ROJO, 2014), o 
processo de retextualização dos gêneros (MARCUSCHI, 2001; DELL'ISOLA, 2007 e BENFICA, 2013), o discurso citado (AUTHIER-REVUZ, 1990; BAKHTIN, 1990; BENITES, 2002; CASTRO, 2009; GARCIA, 2009 e SILVA; BARBOSA, 2016) e a educação especial e inclusiva (MANTOAN, 2015 e SILVA, 2012) fundamentam a parte teórica desta pesquisa.

Este trabalho se compõe de dois produtos: a presente dissertação, com caráter mais teórico e analítico, e um caderno pedagógico, de finalidade pedagógica. Com o caderno, esperase não apenas mostrar a sequência didática realizada na intervenção, mas também proporcionar a possibilidade de outros professores utilizarem esse material, pautando-se em suas próprias realidades para modificarem-no como desejarem.

Neste texto, encontram-se as principais bases teóricas utilizadas para a elaboração da intervenção, o diagnóstico da produção inicial que justifica a pesquisa, a descrição das etapas da intervenção, a análise dos dados e discussão dos resultados.

No próximo capítulo, será apresentada a fundamentação teórica que embasa esta pesquisa. 


\section{PRESSUPOSTOS TEÓRICOS}

Para que o professor-pesquisador cumpra seu papel, é necessário que se paute em bases teóricas e metodológicas que o auxiliem em seu trabalho em sala de aula. Portanto, é de suma importância que os professores estejam sempre pesquisando e conhecendo novas ferramentas e novas teorias que abordam o ensino de língua portuguesa para avançar no ensino de seus próprios alunos. Segundo Antunes (2003),

Não pode haver uma prática eficiente sem fundamentação num corpo de princípios teóricos sólidos e objetivos. Não tenho dúvidas: se nossa prática de professores se afasta do ideal é porque nos falta, entre outras muitas condições, um aprofundamento teórico acerca de como funciona o fenômeno da linguagem humana (ANTUNES, 2003, p.40).

Ainda pensando na importância do aporte teórico para fundamentar a prática no ensino de LP, Costa-Hübes e Simioni (2014) apontam que

\footnotetext{
É a teoria que sustenta o trabalho pedagógico e que norteia (ou ao menos deve nortear) as práticas de sala de aula. Sem o embasamento teórico, corremos o risco de enveredarmos por práticas superficiais e inconsistentes que não garantirão, aos alunos, o conhecimento científico necessário para a formação de sujeitos críticos e participativos. Afinal, como professores, lidamos com a ciência. Logo, precisamos nos manter atualizados, já que o conhecimento também se transforma (COSTA-HÜBES; SIMIONI, 2014, p.17).
}

Nesse contexto, vale ressaltar que a pesquisa ora apresentada buscou desenvolver nos alunos do $8^{\circ}$ ano do ensino fundamental a expansão de conhecimento acerca da língua portuguesa, através dos gêneros textuais orais e escritos, em especial a entrevista e a reportagem, próprios de diferentes situações de comunicação, em diferentes níveis de formalidade, que são contemplados pela BNCC. Por meio dos gêneros, desenvolveu-se um trabalho com os conteúdos gramaticais envolvidos na retextualização dos gêneros, em especial no que diz respeito ao uso dos tipos de discurso. Juntamente com isso, espera-se, por meio da abordagem temática, haver sensibilização e conscientização quanto à valorização das pessoas portadoras de necessidades especiais nos contextos sociais, em especial, dos alunos de educação especial e inclusiva dentro do espaço escolar.

Portanto, para o cumprimento de tal objetivo, pautamo-nos na concepção interacionista, funcional e discursiva da língua, proposta por Antunes. Nessa concepção, "a língua só se atualiza a serviço da comunicação intersubjetiva, em situações da ação social e através de práticas discursivas, materializadas em textos orais e escritos" (ANTUNES, 2003, 
p.42). Dessa forma, podemos concluir que os gêneros textuais ocupam um papel central não só na interação social, mas também no ensino de língua materna, sempre utilizados de acordo com os objetivos da comunicação, sua intencionalidade, situacionalidade e outros aspectos. Além disso, nas palavras de Koch e Elias (2018),

À luz de uma concepção sociocognitiva e interacional da linguagem, o texto
é visto como o próprio lugar da interação verbal e os interlocutores, como
sujeitos ativos, empenhados dialogicamente na produção de sentidos.
Entende-se, pois, a produção de linguagem como uma atividade interativa
altamente complexa em que a construção de sentidos se realiza,
evidentemente, com base nos elementos linguísticos selecionados pelos
enunciadores e na sua forma de organização, mas que requer, por parte destes,
não apenas a mobilização de um vasto conjunto de saberes de ordem
sociocognitiva, cultural, histórica, de todo o contexto, enfim, como também -
e sobretudo - a sua reconstrução no momento da interação (KOCH; ELIAS,
2018, p.10).

Tendo em vista a expansão do conhecimento dos gêneros textuais como instrumento da interação social e a visão de gramática contextualizada adotada pela autora, outras obras de Antunes servirão de base para esta pesquisa.

A pesquisa também é ancorada nos preceitos teóricos de Schneuwly e Dolz que, em "Gêneros Orais e Escritos na Escola", afirmam que "é através dos gêneros que as práticas de linguagem materializam-se nas atividades dos aprendizes" (SCHNEUWLY; DOLZ, 2004, p.63). Assim, quanto maior for a apropriação de gêneros orais e escritos pelos alunos - por se constituírem em práticas de uso - melhor tende a ser seu aprendizado no ensino da língua. Para os autores, é fundamental que a escola ensine os alunos os gêneros textuais escritos e orais nos diversos contextos de comunicação em que podem acontecer. O ideal é que os alunos ampliem seus conhecimentos de leitura, compreensão e produção dos gêneros textuais, seja na escrita ou na fala. Nesse contexto, segundo os autores,

$\mathrm{Na}$ sua missão de ensinar os alunos a escrever, a ler e a falar, a escola, forçosamente, sempre trabalhou com os gêneros, pois toda forma de comunicação - portanto, também aquela centrada na aprendizagem - cristalizase em formas de linguagens específicas (SCHNEUWLY; DOLZ, 2004, p.65).

Além de Schneuwly e Dolz (2004), outros autores como Geraldi (1984), Mendonça (2006), Miranda (2006), Souza e Souza (2012) e Antunes (2014), que tratam o texto como unidade central do ensino de língua, serão destacados ao longo da pesquisa, a fim de confirmar a importância de a escola promover uma maior apropriação dos gêneros textuais como 
instrumentos de interação social pelos alunos. Também abordarmos questões caras aos gêneros entrevista e reportagem, focos da intervenção realizada, bem como do discurso reportado presente na reportagem.

A Análise Linguística (AL) constitui outra base teórica importante para o desenvolvimento deste trabalho, visto que, de acordo com a BNCC, é um eixo sempre trabalhado de forma conjunta com os eixos de leitura, escrita e oralidade. Além disso, a AL vem para substituir as aulas de gramática tradicional, levando a um ensino mais reflexivo, no qual os alunos contribuem para a construção dos conceitos. Desta forma, autores como Geraldi (1984) e Mendonça (2006) servirão de aporte teórico para fundamentar a AL. De acordo com Mendonça (2006),

O ensino de gramática constitui um dos mais fortes pilares das aulas de português e chega a ser, em alguns casos, a preocupação quase exclusiva dessas aulas. Nas duas últimas décadas, entretanto, vem se firmando um movimento de revisão crítica dessa prática, ou seja, vem-se questionando a validade desse "modelo" de ensino, o que faz emergir a prática de análise linguística (AL) em vez das aulas de gramática (MENDONÇA, 2006, p.199).

Além disso, tendo em vista a abordagem dos gêneros e conteúdos propostos para a intervenção pedagógica, faz-se relevante maior conhecimento e reflexão quanto à retextualização. $\mathrm{O}$ processo de retextualização tem como base o uso e conhecimento dos gêneros textuais, uma vez que se refere à transformação de um texto, modificando o gênero textual ao qual pertence ou a modalidade no qual está escrito. Sem que sua percepção seja notada, pratica-se a retextualização em diversas situações cotidianas, como a anotação de pontos relevantes ao participar de uma reunião ou palestra, a transmissão de um recado por chamada telefônica, conversar sobre uma reportagem vista pela televisão, e diversos outros exemplos. Nesse sentido, viu-se a importância de realizar um trabalho que envolvesse o processo de retextualização durante a intervenção, já que, muitas vezes, o processo não é compreendido pelos estudantes, prejudicando a elaboração dos gêneros e as informações contidas no novo gênero produzido. Para o trabalho com a retextualização, Marcuschi (2001), Dell'Isola (2007) e Benfica (2013) serviram como aporte teórico para a pesquisa.

Outra questão que perpassa a intervenção proposta, como já apresentado na introdução deste texto, é a temática da inclusão escolar de alunos com deficiência. Ela é discutida há muitas décadas e, mesmo com todas as vitórias advindas de lutas pela igualdade e pela integração dos alunos com deficiência nas escolas de ensino regular, muito ainda precisa ser feito para que, de fato, eles sejam totalmente incluídos. Segundo Mantoan (2015), 
Ambientes humanos de convivência e de aprendizado são plurais pela própria natureza e, por isso, a educação escolar não pode ser pensada nem realizada senão a partir da ideia de uma formação integral do aluno - segundo suas capacidades e seus talentos - e de um ensino participativo, solidário, acolhedor. A perspectiva de formar uma nova geração dentro de um projeto educacional inclusivo é fruto do exercício diário da cooperação, da colaboração, da convivência, do reconhecimento e do valor das diferenças, que marcam a multiplicidade, a natureza mutante de todos nós (MANTOAN, 2015, p.16).

Nesse sentido, ainda que em um cenário de ensino remoto, tornou-se importante pensar em uma intervenção que sensibilizasse e conscientizasse os estudantes em relação à integração e inclusão das pessoas com deficiência nos diversos contextos de interação social, principalmente, dos alunos com deficiência no espaço escolar. Pensando na inclusão escolar, serviram de base teórica para a pesquisa Mantoan (2015) e Silva, A. (2012).

Portanto, através das bases teóricas a serem apresentadas, a intervenção aplicada a uma turma de $8^{\circ}$ ano do Ensino Fundamental II visou alinhar as teorias, já consagradas pela academia, com práticas reais e reflexivas para o ensino de LP. Para cumprir tal objetivo, os autores supracitados, e outros tão importantes quanto, foram escolhidos para justificar e orientar as etapas elaboradas para a intervenção. A seguir serão abordadas as bases teóricas sobre Análise Linguística, Gêneros Textuais, Retextualização, Gêneros Jornalísticos Entrevista e Reportagem, Multimodalidade, Discurso Citado e Inclusão Escolar.

\subsection{O PAPEL DA ANÁLISE LINGUÍSTICA NO ENSINO DE LÍNGUA MATERNA}

Há anos o ensino da língua materna tem sofrido mudanças significativas no Brasil, norteadas, principalmente, por estudos feitos pela academia e pelos documentos nacionais, como os Parâmetros Curriculares Nacionais (PCN) e a Base Nacional Comum Curricular (BNCC). De acordo com Wachowicz (2012), tais mudanças são justificadas pela história.

Não foram as orientações curriculares do final do século XX que inauguraram a proposta de tratamento da linguagem a partir do discurso. Essa proposta existe de fato há mais de dois mil anos; remonta à filosofia clássica, sobretudo na discussão da natureza retórica (WACHOWICZ, 2012, p.12).

Porém, mesmo com o avanço nas pesquisas sobre o ensino de língua portuguesa, ainda nos deparamos com professores e instituições que prezam pelo uso da Gramática Normativa e por um ensino tradicional. Segundo Sigiliano e Silva (2017), livros didáticos mais recentes, aprovados pelo PNLD (Programa Nacional do Livro Didático), têm evoluído no que tange à apresentação de uma concepção de ensino de gramática mais próxima àquilo que se concebe 
como prática de análise linguística $(\mathrm{AL})$, embora ainda seja bastante frequente a presença de seções e atividades transmissivas nestes materiais. Tal demanda é feita, por vezes, para atender a professores que permanecem arraigados ao ensino de gramática tradicional, como se essa metodologia fosse o único caminho. Nas palavras de Bagno (2010),

\begin{abstract}
A insistência na metodologia transmissiva revela um fenômeno histórico surpreendente: apesar de todas as revoluções epistemológicas e de todas as revoluções políticas e sociais ocorridas nos últimos séculos, o "ensino de gramática" permanece praticamente intocado em seus postulados centrais, muito mais ideológicos do que propriamente linguísticos (BAGNO, 2010, p.42).
\end{abstract}

Segundo Bunzen e Nascimento (2019), alguns são os fatores que dificultam uma mudança significativa nos livros didáticos (LD) e em outros materiais nas aulas de língua portuguesa: a permanência de um ensino mais transmissivo, enfatizando a metalinguagem; um trabalho com a língua preso às divisões e progressões lineares estabelecidas pelas gramáticas escolares; o difícil ato de demarcar os níveis de análise para o trabalho com conhecimentos linguísticos ao longo da educação básica e a convicção de que o conhecimento sobre a gramática de uma língua está pronto, necessitando apenas de transmissão. Tais fatores justificam a presença de seções e atividades transmissivas nos $\mathrm{LD}$, como dito anteriormente. $\mathrm{O}$ foco nas atividades de metalinguagem no ensino de língua portuguesa deve-se à visão que se tem de uma língua estática, que não sofre alteração em nenhum contexto de uso.

Vale ressaltar que a concepção de gramática tradicional adotada nesta pesquisa é a mesma de Franchi (2006), “gramática é o conjunto sistemático de normas para bem falar e escrever, estabelecidas pelos especialistas, com base no uso da língua consagrado pelos bons escritores" (FRANCHI, 2006, p.16), ou seja, o que conhecemos, tradicionalmente, como gramática normativa. Nas palavras de Bunzen e Nascimento (2019), tais normas, na escola, “são geralmente apresentadas como 'fixas' e 'acabadas', com poucas atividades de produção de conceitos, levantamento de hipóteses, análises de dados, comparações entre línguas estrangeiras modernas, etc". (BUNZEN; NASCIMENTO, 2019, p.254).

Por isso, essa metodologia de ensino, há muitos anos, já não tem alcançado resultados satisfatórios no ensino de língua portuguesa. Atrelados a esse ensino tradicional, encontram-se professores desmotivados, que seguem à risca regras e normas apenas de forma transmissiva, e alunos que não compreendem tais conceitos, restringindo-se a decorá-los de forma momentânea e a não ver real sentido e utilidade no "pseudoaprendizado". De acordo com Travaglia (2009), 
O ensino de gramática em nossas escolas tem sido primordialmente prescritivo, apegando-se a regras de gramática normativa que, como vimos, são estabelecidas de acordo com a tradição literária clássica, da qual é tirada a maioria dos exemplos. Tais regras e exemplos são repetidos anos a fio como formas "corretas" e "boas" a serem imitadas na expressão do pensamento (TRAVAGLIA, 2009, p.101).

Travaglia (2009) completa esclarecendo que, nas aulas de língua portuguesa, há poucas atividades direcionadas à produção e compreensão de textos e uma grande concentração de uso da metalinguagem no ensino de gramática teórica, caracterizando um ensino prescritivo, mas muitas vezes questionável. Tal afirmação corrobora o fato de ainda nos depararmos com professores e metodologias presos a formas cristalizadas de ensino da língua, pois se sentem confortáveis com estratégias já consideradas efetivas ou não se sentem seguros para uma mudança significativa no processo de ensino e de aprendizagem.

Contudo, já há muitos anos, no Brasil, estudos e documentos oficiais têm apontado para a necessidade de mudança na forma de se ensinar a língua materna na escola. Levando em consideração o ensino da língua portuguesa, Geraldi, há mais de 30 anos, afirma que "nada será resolvido se não mudar a concepção da língua na escola” (GERALDI, 2012 [1984], p.32). Nesse sentido, cabe ressaltar que, com as mudanças propostas e implementadas no cenário do ensino da língua materna, o texto passou a assumir papel central, em muitas salas de aula e materiais didáticos. Entendendo a função social do texto como instrumento de interação, o ensino de língua pautado nos gêneros tornou-se mais interessante, em detrimento da promoção apenas da sistematização de regras e normas ou da cópia de modelos. Nas palavras de Geraldi (2012 [1984]),

Nesse sentido a alteração da situação atual do ensino de língua portuguesa não
passa apenas por uma mudança nas técnicas e nos métodos empregados na
sala de aula. Uma diferente concepção de linguagem constrói não só uma nova
metodologia, mas principalmente, um "novo conteúdo" de ensino
(GERALDI, 2012 [1984], p.45).

Nesse contexto, a prática de análise linguística surge como proposta de nova metodologia de ensino, substituindo a visão de ensino pautado na gramática normativa, na tentativa de suprir "os resultados insatisfatórios das aulas de gramática e as inconsistências teóricas apresentadas pela gramática normativa” (MENDONÇA, 2006, p.199).

Embora, nas últimas décadas, o ensino de leitura e produção textual tenha avançado, com práticas que refletem situações reais dos nossos alunos, o ensino de gramática não demonstrou avanços tão significativos, permanecendo com frequência arraigado a práticas 
cristalizadas, modelares e tradicionais, em que os alunos não são guiados a refletir sobre o uso da língua e seus fenômenos. A fim de alterar tal perspectiva quanto ao ensino de gramática, é proposta a noção de prática de análise linguística (AL). Como afirma Mendonça (2006),

Por isso, a AL surge como alternativa complementar às práticas de leitura $\mathrm{e}$ produção de texto, dado que possibilita a reflexão consciente sobre fenômenos gramaticais e textual-discursivos que perpassam os usos linguísticos, seja no momento de ler/escutar, de produzir textos ou de refletir sobre esses mesmos usos da língua (MENDONÇA, 2006, p.204).

O termo "análise linguística", voltado para o ensino, foi instituído por Geraldi no livro O texto em sala de aula, publicado em 1984. Nessa obra, o autor explica que o uso do termo "prática de análise linguística" não se deve ao gosto por novas terminologias, e esclarece o fato de que ela inclui o trabalho com questões tradicionais de gramática e questões amplas a propósito do texto, não podendo limitar-se à higienização do texto do aluno, ou seja, a correções. Para Geraldi, o objetivo da prática de análise linguística é a reescrita do texto do aluno, compreendendo o fenômeno linguístico em estudo (GERALDI, 2012 [1984], p.74).

Pensando que a correção do texto escrito e a reescrita do aluno é instrumento proposto por Geraldi para a prática de análise linguística, nada mais natural do que partir do texto do aluno para levantar quais são os fenômenos linguísticos sobre os quais os alunos apresentam maior dificuldade para serem trabalhados em sequências de atividades nas aulas de língua portuguesa. Vários autores propõem a produção textual como ponto de partida para a prática de análise linguística, seguindo o movimento lançado por Geraldi (1984). Conforme apresentado por Mendonça (2006),

Os artigos deste livro já propunham uma reorientação para o ensino de português, como base na leitura e escrita de textos como práticas sociais significativas e integradas, e na análise de problemas encontrados na produção textual como mote para a prática de AL, em vez dos exercícios estruturais de gramática (normativa e descritiva) (MENDONÇA, 2006, p.200).

Além de Mendonça, Souza e Souza (2012) afirmam que a produção de textos, orais ou escritos, apresenta-se como um importante instrumento de exploração de atividades de análise e reflexão sobre os fenômenos linguísticos, já que seu intuito é aperfeiçoar a capacidade dos alunos na produção textual. Miranda (2006), em sua obra A reflexão metalinguística no ensino fundamental, apresenta a hipótese da via de mão-dupla, na qual o texto produzido pelo aluno pode ser usado como fonte diagnóstica pelo professor na investigação de avanços e dificuldades das estruturas linguísticas utilizadas, assim como no uso das estratégias discursivas, 
constituindo uma das direções para a prática do ensino de língua. Por fim, Schneuwly e Dolz (2004), no procedimento "sequência didática", propõem a produção inicial como a primeira etapa do processo de ensino e de aprendizagem, pois com ela o professor consegue definir o que é preciso trabalhar para que o aluno desenvolva as capacidades da linguagem, apropriandose dos instrumentos de linguagem próprios de um determinado gênero. Sendo assim, em consonância com a proposta de Geraldi (1984) para aquilo que se entende por AL, nota-se a relevância de se partir do uso da língua pelo aluno para a identificação de conteúdos a serem trabalhados individual ou coletivamente.

Documentos oficiais, nessa mesma linha, estabelecem distinções entre a prática de análise linguística e o ensino de gramática. Tal distinção é descrita por Vieira (2017), nos seguintes termos:

enquanto a prática de análise linguística toma o texto e as atividades de leitura e produção textual como prioritárias, sendo o componente gramatical utilizado de forma instrumental, o ensino de gramática consideraria, como elemento central da proposta, o componente estrutural, sobretudo nos planos das palavras, oração e período, desvinculado das atividades de leitura e produção textual (VIEIRA, 2017, p.299-300).

Nesse contexto, a nova BNCC descreve o eixo de análise linguística/semiótica como aquele que

envolve o conhecimento sobre a língua, sobre a norma-padrão e sobre as outras semioses, que se desenvolve transversalmente aos dois eixos leitura/escuta e produção oral, escrita e multissemiótica - e que envolve análise textual, gramatical, lexical, fonológica e das materialidades de outras semioses (BNCC, 2017, p.80).

Dessa forma, a BNCC reforça o que pesquisadores como Geraldi, Mendonça e outros, além dos PCN, já afirmavam: a análise linguística deve ser trabalhada de forma conjunta com os outros eixos de ensino da língua. Além disso, nas palavras de Moreira (2019), ao praticar a $\mathrm{AL}$, "entende-se que o ensino de gramática deva ser realizado de modo que a norma culta seja uma das variedades a serem contempladas nas aulas de língua portuguesa, e que o foco da aula sejam o texto e o discurso" (MOREIRA, 2019, p.28). Entende-se aqui o conceito de texto como discurso, conforme escreve Pauliukonis (2007), “o texto considerado um evento em situação dialógica, em que se manifestam elementos linguísticos e extralinguísticos, codificados pela gramática e realizados de acordo com um 'contrato comunicativo' vigente para os diversos gêneros textuais" (PAULIUKONIS, 2007, p.239). 
Segundo Wachowicz (2012), texto e discurso são a mesma coisa, não há como um ser visto ou estudado independente do outro, pois refletir o texto como discurso é considerar a ideologia histórica que o constitui. Para a autora, "não se pode analisar um texto como uma fotografia congelada de formas gramaticais fixas, que justifiquem o trabalho com a gramática, como aparece em um grande número de livros didáticos" (Wachowicz, 2012, p.23).

Entretanto, ainda nas palavras de Wachowicz (2012), ao analisar o papel da gramática dentro dos gêneros textuais, podemos encontrar certos padrões que vão além das imposições formais de convenção da escrita e da fala. De acordo com a autora, há unidades gramaticais que são recorrentes em determinados gêneros textuais, como por exemplo, tempos e modos verbais - pretérito perfeito do indicativo em gêneros narrativos e imperativo em gêneros injuntivos assim como diversos outros casos.

Nessa concepção, marcam-se diferenças consideráveis entre o ensino de gramática e a prática de AL. Em sua obra, Mendonça (2006) desenvolveu um quadro comparativo e detalhou tais diferenças. Para a autora, no ensino de gramática, a concepção da língua como sistema tem uma estrutura inflexível e invariável, diferente da prática de $\mathrm{AL}$, que reconhece a língua como um sistema vivo, um sistema interacional, no qual os falantes interferem a todo e a qualquer momento. No ensino de gramática, as aulas são direcionadas para cada um dos eixos, não havendo integração entre eles, diferente do que acontece nas práticas de AL, que se torna mais uma ferramenta para o trabalho com os eixos de produção e leitura. As atividades metalinguísticas concluem a metodologia transmissiva das aulas de ensino de gramática, ao passo que, na prática de $\mathrm{AL}$, há o trabalho conjunto entre as atividades metalinguísticas e epilinguísticas numa abordagem de ensino mais reflexiva, centrada nos usos como objetos de ensino. Por fim, o ensino de gramática é pautado na norma-padrão, com ausência na especificidade dos gêneros, privilegiando a palavra, a frase e o período como estruturas a serem analisadas por meio de exercícios estruturais, de identificação, classificação e correção. Já na prática de $\mathrm{AL}$, a centralidade está nos efeitos de sentido, trabalhando com os gêneros e contemplando a intersecção das condições de produção textual e escolhas linguísticas. Dessa forma, o texto, ponto de partida e de chegada do ensino, é analisado através de questões que exigem comparação e reflexão sobre adequação e efeitos de sentido (MENDONÇA, 2006, p.207).

Após apontar como se diferenciam os métodos de ensino de gramática e prática de AL, a autora reitera 
Por isso, pode-se dizer que a AL é parte das práticas de letramento escolar, consistindo numa reflexão explícita e sistemática sobre a constituição e o funcionamento da linguagem nas dimensões sistêmica (ou gramatical), textual, discursiva e também normativa, com o objetivo de contribuir para o desenvolvimento de habilidades de leitura/escuta, de produção de textos orais e escritos e de análise e sistematização dos fenômenos linguísticos (MENDONÇA, 2006, p.208).

Como apontado por Mendonça (2006) na citação anterior, a sistematização dos fenômenos linguísticos é uma das habilidades a serem desenvolvidas pela AL. Dessa forma, percebemos que a nomenclatura não é um problema nas aulas de língua portuguesa, pelo contrário, é importante chegar a essa sistematização e fazer com que os alunos reconheçam e saibam nomear os fenômenos que ocorrem na língua. Partindo desse propósito, Suassuna (2012) declara que "precisamos nomear os fenômenos para que possamos nos referir a eles. Assim, não é a aprendizagem da nomenclatura que nos faz aprender a língua; pensar sobre ela é que exige de nós que tenhamos uma linguagem científica própria" (SUASSUNA, 2012, p.22).

Nesse sentido, a sistematização do ensino dos fenômenos que envolvem a língua portuguesa deve ser guiada por meio da reflexão desses mesmos fenômenos, depois que os alunos refletirem sobre seus usos e chegarem aos conceitos com a mediação do professor de língua materna, usando a prática de AL como ferramenta para esse fim. Desse modo, Bunzen e Nascimento (2019) reiteram, "não há problema em usar a metalinguagem. Ela é necessária à atividade de ensino. [...] É por meio da metalinguagem que é possível fazer referência aos objetos de ensino, porque um termo funciona como entrada cognitiva para o acionamento de conceitos" (BUNZEN; NASCIMENTO, 2019, p.255).

Considerando que a língua é interação e que o objetivo do professor de língua portuguesa é preparar o aluno para o exercício de sua cidadania em relação ao uso da língua, através da ampliação do repertório dos gêneros, professores e pesquisadores, a partir da década de 80, mostraram-se inquietos com a abordagem transmissiva no ensino da língua, principalmente nos livros didáticos.

A cada dia, a AL ganha força e não a encontramos apenas na teoria. Diversos professores têm elaborado e publicado materiais didáticos nos quais as práticas são condizentes com essa perspectiva, como se pode notar por meio das coleções aprovadas no PNLD/2020 (SIGILIANO, 2020, no prelo). Ainda que algumas dessas publicações acreditem que estejam abordando o ensino da língua sob uma perspectiva reflexiva, elas usam o texto como pretexto para o ensino, ocupando o plano de fundo para o ensino transmissivo de categorias e classificações. 
A análise dos LD aprovados pelo PNLD feita por Sigiliano e Silva (2017) aponta que a maioria dos conteúdos morfológicos são abordados de maneira mais reflexiva, diferente dos conteúdos de sintaxe, que são abordados de forma transmissiva. Nessa obra, os autores destacam o fato de, nos LD dos anos iniciais do EFII, haver maior aderência do ensino do conteúdo gramatical às práticas de $\mathrm{AL}$, diferente do que ocorre nos anos finais dessa mesma etapa escolar.

Outro ponto relevante na análise dos autores é a abordagem da variação linguística. Segundo Sigiliano e Silva (2017),

a prática de análise linguística garante o trabalho pedagógico com a variação linguística - considerando a importância de compreender e respeitar esse fenômeno intrínseco às línguas - e com os textos pertencentes a diferentes gêneros moldados nas interações cotidianas (SIGILIANO; SILVA, 2017, p.21).

Porém, nas análises feitas pelos pesquisadores em LD aprovados pelo PNLD, observou-se que tal aspecto da língua vem sendo abordado de forma reflexiva como conteúdo, mas sem relevância em outros momentos dos materiais, ficando reservado a uma seção específica dos LD (SIGILIANO; SILVA, 2017, p.37). Em pesquisa referente aos LD aprovados pelo PNLD 2020, Sigiliano (2020, no prelo) revela terem ocorrido avanços maiores no que tange à abordagem da $\mathrm{AL}$ nas distintas seções dos materiais didáticos. Ainda assim, destaca haver coleções de perfil puramente transmissivo e outras em que a reflexão é feita de forma positiva, mas sem guiar à metalinguagem.

À vista disso, mesmo com os avanços feitos pela pesquisa acadêmica e com as mudanças promovidas pelos documentos norteadores, percebe-se que poucas foram as transformações nas práticas dentro de sala de aula no que se refere ao ensino de gramática, uma vez que muitos docentes ainda se mostram resistentes a tais mudanças, seguindo fielmente apenas o que é proposto pelo livro didático.

Tal qual preconiza a prática de AL, podemos afirmar que a gramática é apenas um dos constituintes da língua, já que não existe gramática sem língua. Assim, é através da gramática contextualizada, ou seja, aquela que é inerente à interação social, baseada no uso dos gêneros, que se fará a prática de AL.

Segundo Antunes (2014), "o contexto é parte do poder de significação da linguagem” - itálico da autora - (ANTUNES, 2014, p.40). Logo, é fato que toda gramática que usamos no processo de interação é contextualizada, pois sempre temos uma intenção ao nos comunicarmos uns com os outros, sem desconectar os conteúdos que fazem parte das normas e regras que 
compõem o português, como fonologia e morfologia, por exemplo. Ou seja, nas nossas interações diárias, fica claro que toda gramática é contextualizada, mas, no ambiente escolar, o termo é usado, muitas vezes, para encobrir as mesmas práticas cristalizadas de ensino, aquelas associadas às classificações apenas. Portanto, o que se pode ver na escola é a persistência de uma gramática descontextualizada, uma gramática que decompõe os elementos estruturais da língua portuguesa, analisando classificações de palavras e frases isoladas. Essa gramática, ainda nas palavras de Antunes (2014), refere-se a "um programa em torno de uma língua autônoma, de uma gramática desencarnada, abstraída de uma situação discursiva em que ocorrem cenas, participantes, sentidos, intenções, ajustes, negociações, interação, enfim" (ANTUNES, 2014, p.41).

A proposta de gramática contextualizada condiz com a prática de análise linguística, já que está relacionada ao estudo dos fenômenos gramaticais, tendo em vista seus valores, suas funções e seus efeitos na interação verbal. Para Antunes (2014), o objeto de exploração da gramática contextualizada na escola nada mais é que a compreensão de como os itens gramaticais - de qualquer ordem - concorrem
para a significação (macro ou microestrutural) do texto; que efeitos de sentido
provocam; que funções desempenham; por que acontecem e como acontecem;
nessa ou naquela posição; a que pretensões comunicativas respondem e outros
aspectos, sempre vinculados à condição de que estão presentes no texto por
conta de alguma função ou algum efeito de sentido (ANTUNES, 2014, p.46-
47).

Assim sendo, percebe-se a importância dos gêneros e do papel central do texto no ensino da língua portuguesa. Abordaremos mais sobre os gêneros textuais e seu papel no ensino no tópico da próxima seção.

\subsection{GÊNEROS E SEU PAPEL CENTRAL NO ENSINO DA LÍNGUA}

Para que haja uma mudança real no atual quadro do ensino de língua portuguesa, é preciso que os docentes não só mudem sua concepção de linguagem, assumindo a língua como um sistema vivo, mas também adotem práticas condizentes com essa noção, elaborando materiais que reflitam essa teoria e modificando as abordagens feitas pelos LD sempre que necessário. Para que isso aconteça, é fundamental assumir uma concepção de linguagem enquanto interação social, pois é através dela que nos comunicamos, como afirma Antunes (2014): 
O conceito de "interação", como está sinalizado pela própria composição da palavra, aplica-se a toda "ação" "entre" dois ou mais sujeitos. Representa uma ação conjunta; uma atividade realizada por mais de um agente. No caso específico da linguagem verbal - que é o que nos interessa aqui - a interação, além de ser uma ação conjunta, é uma ação recíproca, no sentido de que os participantes exercem, entre si, mútuas influências, atuam uns sobre os outros na troca comunicativa que empreendem." (ANTUNES, 2014, p.18).

Levando em consideração a linguagem como interação social, é preciso buscar um ensino pautado no uso dos gêneros, já que todas as esferas de atividade humana estão sempre relacionadas com o uso da língua. Logo, é de extrema importância que o ensino se realize através de uma gramática contextualizada, centralizado no uso de enunciados (unidades reais de discurso) que pressupõem interatividade entre sujeitos falantes, e não em palavras e orações isoladas. É fundamental que o repertório de gêneros dos alunos seja ampliado, ressaltando-se o fato de que eles são indicadores de relações de poder na sociedade. Como já dito anteriormente, desde a década de 70, o texto assumiu um papel central no ensino de língua portuguesa; assim, as práticas de ensino têm sido pautadas no estudo dos gêneros textuais. Numa concepção de linguagem na perspectiva sociointeracionista, o ensino norteado pelos gêneros textuais é justificado, visto que não é possível nos comunicarmos verbalmente, senão através de um texto. Dessa forma, a interação social verbal só é possível por meio de algum gênero textual (cf. MARCUSCHI, 2008).

Segundo Marcuschi,

Os gêneros são atividades discursivas socialmente estabilizadas que se prestam aos mais variados tipos de controle social e até mesmo ao exercício de poder. Pode-se, pois, dizer que os gêneros textuais são nossa forma de inserção, ação e controle social no dia-a-dia. Toda e qualquer atividade discursiva se dá em algum gênero que não é $a d$ hoc, como já lembrava Bakhtin ([1953] 1979) em seu célebre ensaio sobre os gêneros do discurso. Daí também a imensa pluralidade de gêneros e seu caráter essencialmente sóciohistórico. Os gêneros também são necessários para a interlocução humana (MARCUSCHI, 2008, p.161).

No momento em que se discute a centralidade do texto no ensino de língua materna, não é apenas o seu papel como ponto de partida e de chegada ao estudo em qualquer um dos eixos ou em qualquer fenômeno linguístico que está em questão. Logo, nas palavras de Schneuwly e Dolz (2004)

trata-se de enfocar, em sala de aula, o texto em seu funcionamento e em seu contexto de produção/leitura, evidenciando as significações geradas mais do 
que as propriedades formais que dão suporte a funcionamentos cognitivos (SCHNEUWLY; DOLZ, 2004, p.10).

Portanto, assim como Marcuschi, Schneuwly e Dolz (2004) adotam uma concepção de gênero como objeto de interação social, denominando-os como um (mega)instrumento para agir em situações de linguagem. Para tal, os autores consideram que todo gênero será definido por três dimensões: conteúdo temático, estilo e construção composicional. Entende-se por conteúdo temático aquilo que pode ser dito através do gênero; como estilo, o conjunto de traços da posição enunciativa, de sequências textuais, de tipos discursivos e de linguagem; e, por fim, como construção composicional, nada mais que a estrutura física do gênero (cf. SCHNEUWLY; DOLZ, 2004).

A partir do momento em que os gêneros textuais passam a ser adotados como instrumentos de ensino e de aprendizagem, algumas dúvidas podem surgir, principalmente, sobre qual (quais) serão utilizados em sala de aula, levando em consideração que os gêneros estão em constante transformação e surgimento. Dessa forma, Marcuschi (2011) pondera

O certo é que o cidadão, mesmo quando não letrado em alto nível, serve-se de um sem-número de gêneros, mas em sua maioria bastante regulados $\mathrm{e}$ padronizados. Diante disso, pode-se indagar se a escola deveria trabalhar com estes preferencialmente ou se deveria deixá-los de lado. Quais seriam aqueles a que ela deveria dedicar-se? (MARCUSCHI, 2011, p.30).

Desse modo, acredita-se que a escola deve trabalhar variados gêneros, a fim de que os alunos se apropriem desse instrumento, ou seja, para Marcuschi (2011), o ensino com base em gêneros deveria orientar-se mais para aspectos da realidade do aluno do que para os gêneros mais poderosos, ou seja, aqueles considerados canônicos pela escola, pelo menos como ponto de partida.

Pensando nisso, deve-se destacar a percepção de que os gêneros textuais contemplados pelos livros didáticos são, em sua maioria, canônicos, ou seja, muitos não são comuns aos contextos de comunicação nos quais os alunos estarão ao longo da vida. Ademais, o LD tem a característica, por razões óbvias, de deslocamento de suporte, e a escola, de distanciamento do papel comunicativo dele. No entanto, o uso dos gêneros no ensino deve se esforçar para estar sempre relacionado a uma situação comunicativa que reflete o cotidiano dos alunos, já que o gênero surge naturalmente na interação social. Nesse aspecto, a BNCC já indica mudanças:

No componente Língua Portuguesa, amplia-se o contato dos estudantes com gêneros textuais relacionados a vários campos de atuação e a várias 
disciplinas, partindo-se de práticas de linguagem já vivenciadas pelos jovens para a ampliação dessas práticas, em direção a novas experiências (BRASIL, 2017, p.136).

Isso posto, pode-se destacar que a vivência em diferentes experiências faz com que os alunos tenham consciência dos gêneros textuais, muitas vezes produzindo-os mesmo sem nunca os ter estudado de forma sistemática. Assim sendo, é papel da escola "levar o aluno ao domínio do gênero, exatamente como este funciona (realmente) nas práticas de linguagem de referência" (SCHNEUWLY; DOLZ, 2004, p.68).

Assim como na prática de $\mathrm{AL}$, o ensino dos gêneros também deve ser feito de forma reflexiva. Através de exercícios de leitura, escuta e comparação, os alunos devem reconhecer as estruturas recorrentes dos gêneros, para perceber posteriormente sua dinamicidade. Nesse exercício comparativo, os alunos, com mediação do professor, percebem as semelhanças entre textos do mesmo gênero a fim de notar sistematicamente quais as estruturas que o compõem e suas características. Para Marcuschi (2008), os gêneros textuais são a materialização, em forma de textos, das situações comunicativas recorrentes:

Os gêneros textuais são os textos que encontramos em nossa vida diária e que apresentam padrões sociocomunicativos característicos definidos por composições funcionais, objetivos enunciativos e estilos concretamente realizados na integração de forças históricas, sociais, institucionais e técnicas (MARCUSCHI, 2008, p.155).

Conforme Souza e Souza (2012), os PCN já apontam que o eixo de produção textual deve ter como objetivo a formação de escritores eficientes, aptos à produção de textos adequados à situação comunicativa em que se encontram, elegendo o gênero textual que atenda, de forma clara e efetiva, aos seus objetivos e à circunstância enunciativa em questão.

Desse modo, reitera-se a ideia de que a comunicação sempre se dá através de gêneros materializados por textos, justificando, portanto, um ensino de língua que esteja pautado na atividade discursiva, na interação verbal.

\subsubsection{A Sequência Didática no ensino de língua portuguesa}

Schneuwly e Dolz (2004) propõem o procedimento da sequência didática para o ensino dos gêneros textuais. De acordo com os autores: "Uma 'sequência didática' é um conjunto de atividades escolares organizadas de maneira sistemática, em torno de um gênero textual oral ou 
escrito" (SCHNEUWLY; DOLZ, 2004, p.82). Nesta pesquisa, adotaram-se os princípios da sequência didática para a elaboração do plano de ação da intervenção. Ou seja, após a produção inicial dos alunos, nos módulos, são elaboradas atividades reflexivas sobre o gênero selecionado e sua estrutura, além de atividades sobre o aspecto gramatical em questão, com o intuito de alcançar resultados satisfatórios na produção final dos alunos.A imagem a seguir demonstra a esquematização de uma sequência didática.

Figura 1 - Modelo de Sequência Didática por Schneuwly e Dolz

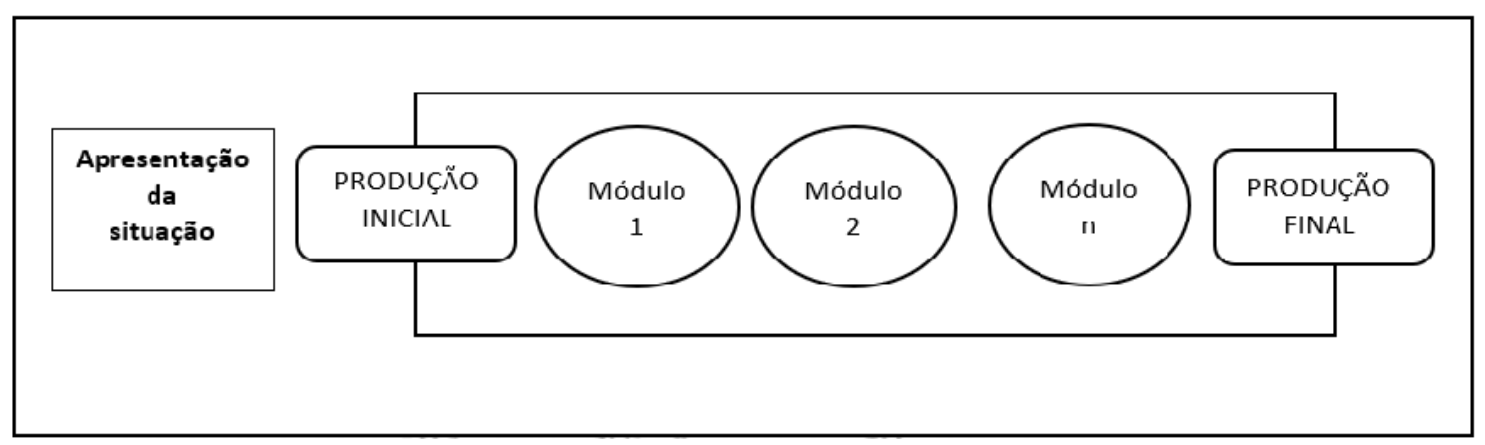

Fonte: Sequência Didática (Schneuwly; Dolz, 2004, p.83).

Nas palavras dos autores, a sequência didática é definida como

(...) um conjunto de atividades escolares organizadas, de maneira sistemática, em torno de um gênero textual oral ou escrito. (...) tem, precisamente, a finalidade de ajudar o aluno a dominar melhor um gênero de texto, permitindolhe, assim, escrever ou falar de uma maneira mais adequada numa dada situação de comunicação (SCHNEUWLY; DOLZ, 2004, p.82-83).

Na proposta de Schneuwly e Dolz (2004), os alunos não são expostos a especificidades do gênero textual que terão que produzir antes da etapa de produção inicial. Esta é vista como um diagnóstico que revelará quais são os conhecimentos que o aluno tem acerca do gênero em questão e quais conhecimentos precisarão ser trabalhados ao longo dos módulos da sequência didática. Assim, ao aluno, é dada a apresentação da situação comunicativa para a produção, ou seja, o gênero escolhido, o público-alvo, o suporte onde o texto aparecerá e o objetivo para sua produção. Após o diagnóstico, feito através da produção inicial, os módulos servirão para contemplar o que não é de domínio dos alunos em relação ao gênero escrito e aos fenômenos linguísticos que são pertinentes a tal gênero. $\mathrm{O}$ objetivo dos módulos é fazer com que as produções textuais dos alunos possam "atender, de modo satisfatório, à necessidade de interlocução apresentada no início da proposta" (COSTA-HÜBES; SIMIONI, 2014, p.25). 
O trabalho com a sequência didática é fundamental, pois possibilita um importante ganho para os alunos no que se refere à expansão de seus conhecimentos sobre os usos e funções de diversos gêneros textuais, sendo ampliado ano após ano ao longo do Ensino Fundamental. Além disso, tal metodologia propicia ao aluno "o reconhecimento, a leitura, a produção, a utilização e a compreensão de diferentes gêneros em contextos sociais distintos" (COSTAHÜBES; SIMIONI, 2014, p.17).

Costa-Hübes e Simioni (2014) propõem, para os anos iniciais do Ensino Fundamental, o acréscimo de duas etapas na estrutura da sequência didática de Schneuwly e Dolz (2004), justificando tais modificações por conta das peculiaridades das condições socioeducacionais no contexto brasileiro. As etapas propostas pelas autoras são o módulo de reconhecimento e a circulação do gênero, de acordo com o esquema a seguir:

Figura 2 - Modelo de Sequência Didática por Costa-Hübes e Simioni

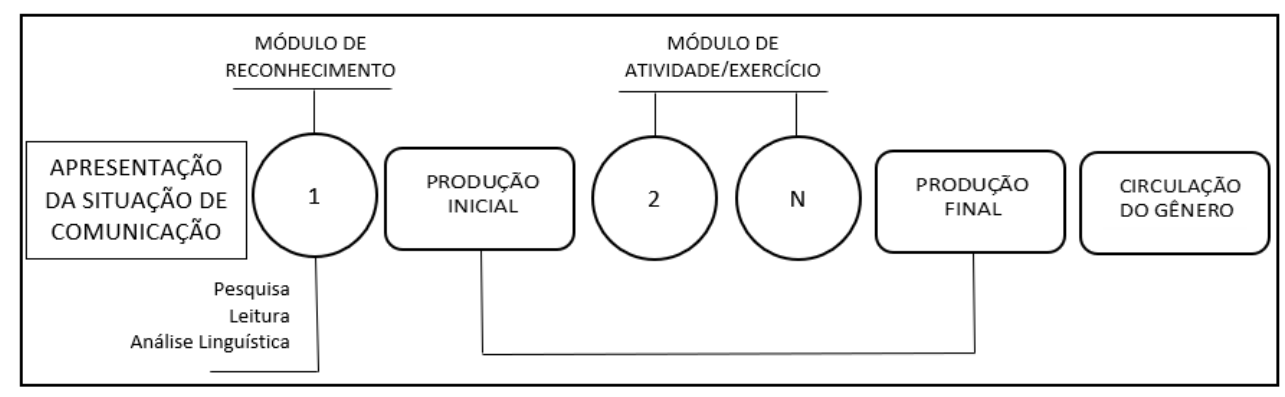

Fonte: Esquema de sequência didática adaptada por Costa-Hübes (COSTA-HÜBES; SIMIONI, 2014, p.26).

O módulo de reconhecimento dos gêneros propõe desenvolver com os alunos atividades de pesquisa, leitura e análise linguística do gênero em estudo. Portanto, seria dado contato ao aluno com diversos textos ditos modelares, para que este reconhecesse o gênero textual que seria estudado durante a sequência didática. Nas palavras das autoras, o contato prévio dos alunos com o gênero e seu conhecimento "pode deixá-los mais seguros no momento da primeira produção" (COSTA-HÜBES; SIMIONI, 2014, p.27). Já o módulo de circulação do gênero tem o objetivo de fazer com que os textos produzidos circulem, ou seja, sejam compartilhados, para que se cumpra o uso real da linguagem, assumindo a concepção de língua sociointeracionista.

Magalhães e Cristovão (2018) também propõem adaptações na estrutura da sequência didática, uma vez que discordam de alguns pontos presentes na estrutura de Schneuwly e Dolz 2004), como por exemplo, a ausência de circulação da produção textual, a modificação ou adaptação do gênero ao contexto escolar e, em alguns casos, a necessidade de ficcionalização 
da situação comunicativa, fatos que afastam o estudo do gênero das interações que acontecem fora do ambiente escolar.

De acordo com Magalhães e Cristovão (2018), “a sequência didática de gêneros textuais foi expandida e reinterpretada de muitas formas" (MAGALHÃES; CRISTOVÃO, 2018, p.33); logo, sua interpretação pode ser feita de variadas maneiras "reapropriando-nos do mesmo conhecimento, dependendo dos pressupostos teórico-metodológicos que nos orientam, bem como guiados por diferentes conceitos e práticas pedagógicas, dando novas interpretações ao tema" (MAGALHÃES; CRISTOVÃO, 2018, p.33).

Neste trabalho, serão considerados princípios do modelo de sequência didática proposto por Schneuwly e Dolz (2004). Considerando outros modelos de sequência didática, adaptados para diferentes realidades e propósitos, o apresentado por Costa-Hübes e Simioni (2014) também se revelou interessante para ser adotado na intervenção, visto que contempla a apresentação do gênero que será produzido, mesmo que de forma superficial, sem o aprofundamento em suas características prototípicas, assim como a circulação dos textos produzidos, ao final da intervenção.

Assim sendo, como já explicitado, a intervenção desta pesquisa assume princípios da sequência didática propostos por Schneuwly e Dolz (2004) e por Costa-Hübes e Simioni (2014), com módulos de intervenção adaptados de acordo com o desenvolvimento do projeto, com o uso da produção inicial para o levantamento e análise de dados para o desenvolvimento das aulas, com a aplicação de atividades que despertem conhecimentos prévios dos alunos para a produção, com a produção final como ferramenta para a análise dos resultados obtidos e a circulação dos textos produzidos.

\subsubsection{Os gêneros textuais do campo jornalístico/midiático}

A Base Nacional Comum Curricular (BNCC) divide os gêneros textuais que circulam na sociedade em diferentes campos de atuação, sendo um deles o campo jornalístico/midiático. Nos anos finais do Ensino Fundamental, o tratamento dos gêneros que circulam nessa esfera pública é aprofundado. Para a BNCC (2017),

Trata-se, em relação a este Campo, de ampliar e qualificar a participação das crianças, adolescentes e jovens nas práticas relativas ao trato com a informação e opinião, que estão no centro da esfera jornalística-midiática. Para além de construir conhecimentos e desenvolver habilidades envolvidas na escuta, leitura e produção de textos que circulam no campo, o que se pretende é propiciar experiências que permitam desenvolver nos adolescentes e jovens a 
sensibilidade para que se interessem pelos fatos que acontecem na sua comunidade, na sua cidade e no mundo e afetam as vidas das pessoas, incorporem em suas vidas a prática de escuta, leitura e produção de textos pertencentes a gêneros da esfera jornalística em diferentes fontes, veículos e mídias, e desenvolvam autonomia e pensamento crítico para se situar em relação a interesses e posicionamentos diversos e possam produzir textos noticiosos e opinativos e participar de discussões e debates de forma ética e respeitosa (BRASIL, 2017, p.138).

Devido a sua relevância social, o estudo dos gêneros jornalísticos é fundamental para a educação e formação crítica do cidadão. Logo, cabe ao professor de ensino da língua o aprofundamento de tais gêneros textuais em suas aulas, visto que toda sociedade é influenciada por eles. Nesse sentido, de acordo com Bonini (2011), “o indivíduo necessita conhecer a linguagem dessa comunidade, ou seja, precisa ingressar naquele discurso e, principalmente, dominar os gêneros que ali são praticados" (BONINI, 2011, p.55).

Tendo em vista que os gêneros do campo jornalístico priorizam os fatos sociais de interesse geral e apresentam linguagem voltada para diversos púbicos, eles se tornam ótimas alternativas para a elaboração de material didático para o estudo dos eixos de leitura, produção textual oral ou escrita e, também, análise linguística/semiótica. Assim, justifica-se a escolha dos gêneros entrevista e reportagem, nas modalidades oral e escrita, não só pensando na importância do processo de retextualização presente em sua produção e crucial nesta proposta, mas também na relevância da compreensão desses gêneros textuais para as práticas de linguagem e formação crítica do cidadão.

A seguir, trataremos, mais especificamente, dos gêneros textuais que serviram como base para a intervenção: a entrevista e a reportagem.

\subsubsection{O gênero textual entrevista e a retextualização como instrumento para o ensino de LP}

Como já mencionado, documentos norteadores do ensino, como a BNCC (2017) e os PCN (1998), apontam a importância de proporcionar aos alunos a ampliação do conhecimento dos gêneros textuais relacionados às práticas de linguagem cotidianas, não só em relação ao seu uso e função, mas também à sua compreensão crítica.

Sendo assim, a entrevista se constitui em um gênero textual de grande impacto na sociedade atual, seja por sua função primária de informar ao público e/ou formar opinião pública, seja nos diferentes propósitos que ela pode apresentar em nossa vida, como, por exemplo, a entrevista de emprego. 
Diferentemente de uma habitual conversa, a entrevista possui uma estrutura controlada de perguntas e respostas, na qual dois papéis são realizados: o de entrevistador (quem pergunta) e o de entrevistado (quem responde). De acordo com Hoffnagel (2010),

o modelo canônico da entrevista é composto de, pelo menos, dois indivíduos, cada um com um papel específico: o entrevistador, responsável pelas perguntas, e o entrevistado, responsável pelas respostas (HOFFNAGEL, 2010, p.196).

Nas palavras de Schneuwly e Dolz (2004), diversos autores

consideram a entrevista uma prática de linguagem altamente padronizada, que implica expectativas normativas especificas da parte dos interlocutores, como num jogo de papéis: o entrevistador abre e fecha a entrevista, faz perguntas, suscita a palavra do outro, incita a transmissão de informações, introduz novos assuntos, orienta e reorienta a interação; o entrevistado, uma vez que aceita a situação, é obrigado a responder e fornecer as informações pedidas (SCHNEUWLY; DOLZ, 2004, p.73).

Em sua grande maioria, as entrevistas referem-se a manifestações de interação oral, independente do seu propósito comunicativo. Para as entrevistas que se manifestam na modalidade escrita, leiam-se aqui sobretudo as entrevistas do campo jornalístico, muitas vezes, ocorrem primeiramente de forma oral e passam pelo processo de transcrição para sua publicação. Depois desse processo, a entrevista escrita assemelha-se a uma conversa na qual a mudança de turnos de fala entre entrevistador e entrevistado tem caráter controlado.

Esse processo demanda a retextualização e Marcuschi (2001) aponta como exemplo de retextualização a transformação da entrevista oral para a entrevista escrita, em que se mantém o gênero, mas muda-se a modalidade da língua. Segundo o autor, "existem transcrições que já são um primeiro formato de retextualização" (MARCUSCHI, 2001, p.52), uma vez que introduzem mudanças como a inserção de pontuação e a eliminação de hesitações, pausas e repetições. Marcuschi diz que é importante diferenciar a simples transcodificação, que é passagem do sonoro para o gráfico, do processo de retextualização, que é a adaptação/transformação textual entre modalidades ou entre gêneros, ou seja, "o que o jornalista faz quando 'revê' ou 'corrige' passagens de uma entrevista oral (gravada) que será publicada" (MARCUSCHI, 2001, p.52).

Tais estratégias envolvidas no processo de retextualização, primeiramente, da entrevista oral para a entrevista escrita e, posteriormente, da entrevista para a reportagem, contribui de forma efetiva para o trabalho com o eixo de análise linguística/semiótica, visto que aspectos como pontuação, substituição lexical e eliminação de hesitações, pausas e marcas de oralidade, 
na primeira; e a inserção do discurso reportado, na segunda, são extremamente relevantes para sua construção. No caso deste trabalho, além da observação e análise de entrevistas orais e escritas, os alunos foram incentivados à produção de entrevistas e a atividades de retextualização. Na intervenção, os estudantes puderam vivenciar essa prática de linguagem por meio da leitura e da produção de textos, que ocorreu através da troca de áudios, devido ao distanciamento social por conta da pandemia da Covid-19, passando pela experiência de construir um gênero textual oral e registrá-lo, também, na modalidade escrita.

\subsubsection{O gênero reportagem como ferramenta para o ensino de LP}

O gênero textual reportagem, nas modalidades oral e escrita, faz parte do campo jornalístico/midiático, cuja função é informar ao público e/ou formar opinião pública. Os suportes mais comuns para esse gênero textual são a revista e o jornal, sejam eles orais, impressos ou online. No que tange à relação entre gênero e suporte, Marcuschi (2008) aponta que "ele é imprescindível para que o gênero circule na sociedade e deve ter alguma influência no caso do gênero suportado" (MARCUSCHI, 2008, p.174), já que a identificação do gênero está relacionada ao suporte em que é veiculado e a observação dessa relação foi incentivada nas atividades da intervenção apresentada neste texto.

De acordo com a obra Glossário de Gêneros e Suportes Textuais, concebe-se o gênero reportagem como aquele que

tem por objetivo divulgar um fato, mas de maneira mais aprofundada que a notícia, com elementos de comprovação e descrição detalhada. Circula, geralmente, em jornais e revistas e tem como público-alvo aqueles que consomem esses veículos. Como movimentos textuais, apresenta manchete assim como a notícia -, lead e corpo do texto que pode ser dividido em subseções de acordo com o assunto desenvolvido (PINTON; STEINHORST; BARRETO, 2020, p.31)

O objetivo, a organização geral do gênero e a função do texto que nele se insere são objetos de ensino-aprendizagem das atividades propostas na intervenção a ser apresentada.

Como já mencionado, a reportagem tem muita relevância na esfera jornalística, uma vez que a divulgação do fato é comprovada através de diferentes fontes, como dados coletados ou entrevistas. Sua composição pode ser influenciada pelo suporte em que está inserida, pelo público-alvo a que se destina, além da temática abordada. Baltar (2004) caracteriza a reportagem como um gênero complexo e elaborado. Nas palavras do autor, 
A reportagem é o gênero mais complexo e mais elaborado do jornalismo. Envolve coleta minuciosa de dados, entrevistas, consulta a outras mídias como rádio, TV e internet. Predominam os tipos de discurso no mundo do narrar: narração e o relato interativo, com sequências narrativas, descritivas e dialogais (BALTAR, 2004, p.132)

Como características do gênero textual reportagem, podemos afirmar que seu propósito comunicativo é informar a respeito de um assunto, mostrado através da perspectiva do repórter. Por isso, um recurso muito utilizado na construção da reportagem é a inclusão de outras vozes no texto. Nas palavras de Silva (2012),

Essa inclusão permite que o texto seja visto como abordando o tema de uma forma global e que o jornalista se isente da apresentação dos fatos. Por isso é recorrente em textos que instanciam o gênero reportagem a utilização de discurso direto e discurso indireto, com o intuito de marcar outras vozes trazidas para o texto (SILVA, T., 2012, p.194).

Tal característica da reportagem faz com que esse gênero se torne relevante na pesquisa, visto que as análises iniciais dos textos dos alunos revelaram dificuldade de uso do discurso reportado em textos escritos.

\subsubsection{A relação entre multimodalidade e gêneros textuais}

A construção de textos a partir de diferentes tipos e modos de representação, ou seja, por elementos linguísticos e não linguísticos, compõe os textos multimodais. Nas palavras de Rojo (2014), os textos têm mudado com o tempo e, na vida contemporânea:

(...)os escritos e falas se misturam com imagens estáticas (fotos, ilustrações, gráficos, infográficos) e em movimento (vídeos) e com sons (sonoplastias, músicas), a palavra texto se estendeu a esses enunciados híbridos de "novo" tipo, de tal modo que hoje falamos também em textos orais e em textos multimodais (ROJO, 2014, s.n.).

Para a autora, esses "novos escritos" são resultados de novas tecnologias e ferramentas de que dispomos atualmente. Porém, o termo multimodalidade, apesar de ganhar força apenas no final do século 20 através dos estudos de Kress e Van Leeuwen (1996), não é novidade, pois é inerente às práticas comunicativas.

No Brasil, Marcuschi (2008), apoiado nos estudos de Beaugrande (1997), aponta o texto como um evento multissistêmico que envolve aspectos linguísticos e não linguísticos na sua 
construção, tornando o texto multimodal. Nessa mesma linha, Cavalcante (2012) delimita ainda mais o conceito de texto, sendo

um evento comunicativo em que estão presentes os elementos linguísticos, visuais e sonoros, os fatores cognitivos e vários aspectos (...) um evento de interação entre locutor e interlocutor, os quais se encontram em um diálogo constante (CAVALCANTE, 2012, p.20).

Neste trabalho, adotamos a concepção de texto multimodal proposta por Kress e Leeuwen (1996) e Kress $(2003,2010)$, segundo a qual o texto multimodal é construído por mais de um código semiótico. Para os autores, toda e qualquer escolha feita na produção de um texto, sejam imagens, ilustrações e gráficos, sejam o tamanho da fonte, a paragrafação, os espaçamentos dentre outros, contribuem para a construção de seu sentido e buscamos explorar essas múltiplas dimensões quando da abordagem de videoanimações e da entrevista, por exemplo.

A partir de tais concepções, podemos pensar no quão difícil é, nos dias atuais, encontrar o isolamento de um texto como sendo puramente verbal ou puramente visual, sendo a grande maioria das produções de caráter multimodal. Ribeiro (2016) também aponta a importância do jogo de linguagens na produção e leitura dos textos multimodais, o que foi considerado no momento de elaboração das atividades propostas nesta intervenção e explicitadas no caderno pedagógico:

E quantas linguagens há amalgamadas em qualquer jornal ou revista, hoje? O que se escolhe dizer com palavras ou com fotos? O que se escolhe deixar subentendido? O que se escolhe narrar com palavras ou com desenhos? Que informações surgem na forma de números ou na forma de gráficos? Que informações podem ser dadas como tabelas ou como infográficos?

E quem lê tudo isso? Onde se aprende a ler assim? O que dizem nossas avaliações massivas (Enem, Pisa...) sobre a leitura de textos multimodais? Como a escola vem trabalhando textos compostos por várias linguagens? Ainda há professores de português que descartam fotos, ilustrações, gráficos e outros elementos e apresentam aos alunos apenas o texto verbal de uma reportagem? (Ribeiro, 2016, p.26)

Esses questionamentos nunca foram tão discutidos como agora e tais reflexões precisam ser feitas por todos os docentes de forma urgente. Como forma de incorporar tais reflexões e discussões, a intervenção apresentada aqui teve como intuito abordar diversos textos multimodais e explorar suas características estruturantes com frequência. 


\subsection{O PROCESSO DE RETEXTUALIZAÇÃO NO ENSINO DE LP}

Marcuschi (2001) propõe a retextualização como o processo de passagem ou transformação do texto falado para o texto escrito, ou seja, da modalidade oral para a modalidade escrita. Essa passagem, apesar de ser realizada de forma mecânica pelos falantes, não é feita de maneira natural no processo de textualização, já que envolve muitas operações complexas. Nas palavras de Marcuschi, a retextualização

(...) não é um processo mecânico, já que a passagem da fala para a escrita não se dá naturalmente no plano dos processos de textualização. Trata-se de um processo que envolve operações complexas que interferem tanto no código como no sentido e evidenciam uma série de aspectos nem sempre bemcompreendidos da relação oralidade-escrita (MARCUSCHI, 2001, p.46).

Em consonância com Marcuschi (2001), Dell'Isola (2007) afirma que a retextualização, além de ser uma atividade comum, pode acontecer de forma bastante diversificada, podendo um mesmo conteúdo ser retextualizado de diversos modos. Nas palavras de Dell'Isola (2007), retextualização é

um processo que envolve operações complexas que interferem tanto no código quanto no sentido e evidencia uma série de aspectos da relação entre oralidade-escrita, oralidade-oralidade, escrita-escrita, escrita-oralidade (DELL'ISOLA, 2007, p.36).

Além do processo indicado por Marcuschi (2001), o processo de retextualização pode ser feito através de diversas possibilidades, ou seja, não só do texto oral para o texto escrito, mas também nas várias combinações entre essas modalidades, incluindo os textos multimodais. Matencio (2002) parte do princípio de que "retextualizar é produzir um novo texto a partir de um texto-base, pressupondo-se que essa atividade envolva também relações entre gêneros e textos - o fenômeno da intertextualidade - quanto relações entre discursos - a interdiscursividade". Para Benfica (2013), "denomina-se retextualização o processo de produção de um novo texto a partir de um ou mais textos-base", destacando ser esta também atividade frequente em nosso cotidiano. Assim, podemos dizer que há uma harmonia entre os pesquisadores sobre o conceito de retextualização como um processo de modificação do texto entre modalidades ou entre gêneros, sendo o mesmo adotado nessa pesquisa. 


\subsubsection{A relação entre oralidade e escrita}

Estudos anteriores à década de 80 apontavam as práticas de oralidade e de escrita como opostas e indicavam uma supremacia da escrita em relação à fala (MARCUSCHI, 2001, p.16). A partir da década de 80, tal visão se alterou e novas concepções surgiram.

De acordo com a concepção interacionista da linguagem, "são os usos que fundam a língua e não o contrário" (MARCUSCHI, 2001, p.9). Portanto, o primordial é saber usar a língua adequadamente, produzindo o efeito de sentido desejado, de acordo com a situação comunicativa. Sendo assim, não há uma superioridade da escrita em relação à fala, como muitos ainda acreditam. Defendemos, assim como Marcuschi (2001), que as relações entre fala e escrita não são estanques e dicotômicas, mas sim estreitas, havendo, em certas situações, "uma fusão de ambas, numa sobreposição bastante grande tanto nas estratégias textuais como nos contextos de realização" (MARCUSCHI, 2001, p.9).

Nesse sentido, Marcuschi trata a relação entre fala e escrita como um continuum, no qual os gêneros textuais de ambas as modalidades apresentam níveis de linguagem que vão do mais informal e espontâneo até os níveis mais formais e rígidos, havendo ainda os gêneros híbridos ou mistos, uma vez que "são de difícil localização em uma ou outra modalidade" (MARCUSCHI, 2008, p.198).

Outros estudos divergem do posicionamento de Marcuschi (2001; 2008), mesmo que tal ponto de vista não seja o mais convencional atualmente. Kress (2003 apud Ribeiro, 2016) aponta que fala e escrita são modalidades diferentes, sendo importante aprendê-las e manuseálas correta e adequadamente. Nas palavras do autor, "o ponto de vista que advogo aqui é o de que elas são modos diferentes" (KRESS, 2003, p.31, apud RIBEIRO, 2016, p.12).

Embora sejam modalidades distintas, compactuamos com o mesmo pensamento de Marcuschi (2001) em relação a elas:

Oralidade e escrita são práticas e usos da língua com características próprias, mas não suficientemente opostas para caracterizar dois sistemas linguísticos nem uma dicotomia. Ambas permitem a construção de textos coesos e coerentes, ambas permitem a elaboração de raciocínios abstratos e exposições formais e informais, variações estilísticas, sociais, dialetais e assim por diante. As limitações e os alcances de cada uma estão dados pelo potencial do meio básico de sua realização: som de um lado e grafia de outro, embora elas não se limitem a som e grafia (...) (MARCUSCHI, 2001, p.17). 
Rojo (2006) também aponta problemas ao considerar fala e escrita como modalidades dicotômicas, mesmo que tal relação seja adequada para alguns momentos e usos. Rojo (2006) assume que

não podemos dizer que sempre a fala - mesmo a conversa cotidiana - é desorganizada, variável, fragmentária, heterogênea. Apenas que ela tem um outro tipo de organização, adequada ao gênero textual e ao contexto. $\mathrm{O}$ mesmo para a escrita, que pode assumir diversas formas de organização, de acordo com o gênero e o contexto. Não podemos dizer que um jornal falado televisivo é não planejado, assim como não podemos dizer que planejamos nossas anotações de diário íntimo (ROJO, 2006, p.33)

Para Rojo (2006), “a perspectiva adotada por Marcuschi apresenta uma versão bastante mais sofisticada das relações entre oral e escrita nos usos sociais da língua" (Rojo, 2006, p.39), neutralizando muitos dos mitos sobre uma possível dicotomia.

Dessa forma, tendo em vista o processo de retextualização, a concepção do continuum na relação entre fala e escrita é fundamental, visto que o que é feito durante esse processo interfere na materialidade, na forma e no conteúdo do texto, seja na retextualização entre modalidades, seja na retextualização entre gêneros. É nessa perspectiva que conduzimos a abordagem de alguns gêneros dispostos na intervenção apresentada no caderno pedagógico.

\subsubsection{A retextualização em sala de aula}

Muito mais do que se imagina, o processo de retextualização é recorrente nas atividades cotidianas. Em diversas situações, transformam-se textos orais em escritos, e vice-versa, ou se faz a mudança de um gênero textual para outro. Como exemplos, podem ser citados: fazer notas em uma reunião ou em uma aula expositiva, transmitir o conteúdo de um ofício em forma de aviso ou recado, conversar sobre uma notícia lida, contar o enredo de um filme, e tantas outras situações. Na produção dessas retextualizações, realizam-se processos linguísticos complexos e importantes, os quais não são selecionados ou organizados por seus produtores, mas feitos de forma automática e natural, como se esse conhecimento fosse internalizado por todos os falantes.

Para que a retextualização seja feita de forma correta, a compreensão do texto é fundamental, assim como a compreensão do comando de produção, ou seja, assimilar e entender não só o conteúdo do texto, mas também a forma como tal texto deve ser transformado. Segundo Marcuschi (2001), 
(...) para dizer de outro modo, em outra modalidade ou em outro gênero o que foi dito ou escrito por alguém, devo inevitavelmente compreender o que foi que esse alguém disse ou quis dizer. Portanto, antes de qualquer atividade de transformação textual, ocorre uma atividade cognitiva denominada compreensão. Esta atividade, que em geral se ignora ou se dá por satisfeita e não problemática, pode ser a fonte de muitos problemas no plano da coerência no processo de retextualização (MARCUSCHI, 2001, p.47).

Portanto, pode-se afirmar que a compreensão é uma atividade cognitiva fundamental para o processo de retextualização, em todas as suas possibilidades. Dell'Isola (2007) também aponta a importância da compreensão para o processo de retextualização, colocando-a como uma atividade que favorece a produção textual. Para a autora,

As atividades de retextualização englobam várias operações que favorecem o trabalho com a produção de texto. Dentre elas, ressalta-se um aspecto de uma imensa importância que é a compreensão do que foi dito ou escrito para que se produza outro texto. Para retextualizar, ou seja, para transpor de uma modalidade para a outra ou de um gênero para outro, é preciso, inevitavelmente, que seja entendido o que se disse ou se quis dizer, o que se escreveu e os efeitos de sentido gerados pelo texto escrito (DELL'ISOLA, 2007, p.14).

Vale ressaltar que existem diferenças entre os processos de retextualização, de reescrita e de revisão (BENFICA, 2013), mesmo que estes possam estar presentes naquele. Para Dell'Isola (2007), "retextualização é a refacção ou a reescrita de um texto para outro, ou seja, trata-se de um processo de transformação de uma modalidade textual em outra, envolvendo operações específicas de acordo com o funcionamento da linguagem" (DELL'ISOLA, 2007, p.36). Já Marcuschi (2001) declara que podemos usar as expressões refacção e reescrita em substituição ao termo retextualização.

Embora Marcuschi (2001) e Dell'Isola (2007) não demonstrem preocupação na distinção entre os termos retextualização, refacção e reescrita, empregando-os como intercambiáveis em alguns momentos e como processos distintos em outros, Benfica (2013) assume a postura de que tais termos não são intercambiáveis. Nesse sentido, os autores d'Andrea e Ribeiro (2010) propõem que

a retextualização seja uma modificação mais ampla do texto, inclusive, podendo-se alterar o meio em que ele é produzido/veiculado (entrevista oral para a notícia escrita, por exemplo, ou do texto impresso para a notícia de rádio). A reescrita, diferentemente, só poderia ocorrer do escrito para o escrito. Dessa distinção, pode-se propor que toda retextualização é reescrita, mas nem toda reescrita gera uma retextualização (D’ANDREA; RIBEIRO, 2010, p.66). 
Como já definido anteriormente, a retextualização, como um processo de transformação textual, passando o texto de uma modalidade para outra e de um gênero para outro, implica mudanças significativas na estrutura do texto e no seu objetivo comunicativo. Já os processos de reescrita e revisão têm por objetivo o amadurecimento, a melhora na produção de um mesmo texto (modalidade e gênero) para atender melhor seu propósito comunicativo. Portanto, a reescrita e a revisão são etapas para se refazer um texto, estando assim, presentes no processo de retextualização. Nas palavras de Benfica (2013),

Chamamos de retextualização o processo de criação de um novo texto a partir de um ou mais textos-fonte, processo esse que implica modificações profundas, em função da alteração dos propósitos comunicativos, da modalidade textual ou dos gêneros. Já a revisão e a reescrita são entendidas como etapas do processo de refacção de um texto produzido, antes de sua publicação (BENFICA, 2013, p.31-32).

Para o presente trabalho, foi adotada a mesma postura que Benfica assume, uma vez que se acredita que a retextualização de um gênero a outro, assim como de uma modalidade a outra, provoca mudanças significativas no texto. Ademais, considera-se que a revisão e a reescrita são etapas importantes para que a versão final da retextualização atenda aos propósitos comunicativos do gênero escrito, bem como seus contextos de produção e circulação.

Como o objetivo desta pesquisa é a retextualização de um texto da modalidade oral para a modalidade escrita, também é fundamental a distinção entre o termo retextualização e transcrição, visto que este não causa interferência no discurso, mas aquele sim. De acordo com Marcuschi (2001),

Transcrever a fala é passar um texto de sua realização sonora para a forma gráfica com base numa série de procedimentos convencionalizados. Seguramente, neste caminho, há uma série de operações e decisões que conduzem a mudanças relevantes que não podem ser ignoradas. Contudo, as mudanças operadas na transcrição devem ser de ordem a não interferir na natureza do discurso produzido do ponto de vista da linguagem e do conteúdo. Já no caso da retextualização, a interferência é maior e há mudanças mais sensíveis, em especial no caso da linguagem (MARCUSCHI, 2001, p.49).

Dessa maneira, pode-se dizer que a transcrição é a primeira transformação, mas ainda não é um processo de retextualização, pois o texto falado é mantido da forma mais fidedigna possível na passagem para o texto escrito. Esse processo também pode ser chamado de transcodificação. 
Porém, existem transcrições que já se enquadram no formato da retextualização, uma vez que sofrem algumas adaptações, como por exemplo, a inserção de pontuação, a eliminação de hesitações ou a formação de paráfrases. Para Marcuschi (2001),

(...) as operações de retextualização na passagem da fala para a escrita são atividades conscientes que seguem os mais variados tipos de estratégias. Em certos casos, algumas formas lingüísticas são eliminadas e outras introduzidas; algumas são substituídas e outras reordenadas. Nesse processo de reescrita (que vai além da transcodificação inicial da fala), entram em ação algumas estratégias de regularização linguística. Estas são, em geral, as primeiras alterações e têm muito a ver com os fenômenos mais estreitamente relacionados à denominada norma linguística padrão, sendo assim atividades elementares ligadas à corretude intuitiva. Posteriormente, surgem outras operações que afetam as estruturas discursivas, o léxico, o estilo, a ordenação tópica, a argumentatividade e acham-se ligadas à reordenação cognitiva e à transformação propriamente dita que atinge a forma e a substância do conteúdo pela via da mudança na qualidade da expressão (MARCUSCHI, 2001, p.55).

Além da transcrição, da transcodificação e da adaptação, há também o processo de editoração, cujas regras são usadas pelos gramáticos para transformar os dados com o objetivo de torná-los analisáveis, ou seja, gramaticais, não prevendo mudanças estilísticas ou de sequenciação. Nesse processo, ocorre uma eliminação mínima (pausas, repetições, inserções, correções, entre outras). Logo, não há modificação no material linguístico produzido pela fala, além do necessário. Aqui, podemos exemplificar uma entrevista oral que será publicada impressa em um jornal, pois, ao lermos tal entrevista, não nos damos conta das hesitações, correções, etc., produzidas pelo entrevistado ao longo da entrevista.

Marcuschi (2001), ao observar que poucos foram os estudos feitos através de análises no processo de transformação fala-escrita, realizou uma experiência em 1989 para formular hipóteses e o modelo das estratégias seguidas nessa possibilidade de retextualização. Os resultados de seu estudo indicaram que "as transformações seriam recorrentes, sucessivas e hierarquicamente ordenadas" (MARCUSCHI, 2001, p.66). Seu modelo foi desenvolvido em três etapas: transformações linguístico-textuais, operações de natureza cognitiva (compreensão) e tratamento estrutural da sequência conversacional dos turnos para o caso dos diálogos, conforme demonstrado no quadro abaixo: 
Figura 3 - Aspectos envolvidos na retextualização por Marcuschi

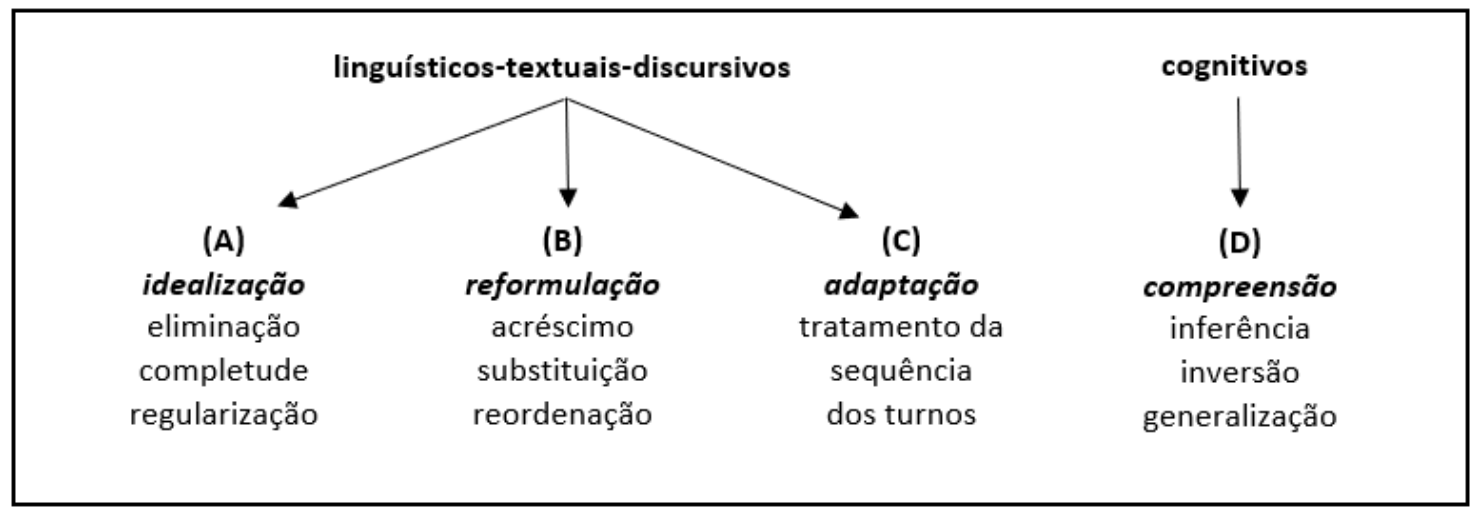

Fonte: Aspectos envolvidos no processo de retextualização (MARCUSCHI, 2001, p.69).

Marcuschi (2001) apresenta um modelo das operações de retextualização do texto oral para o texto escrito, embora acredite que a formulação de um modelo seja algo perigoso, uma vez que, muitas vezes, é tomado como uma "fórmula mágica" que deve produzir resultados quando aplicada. Dessa forma, o autor diz que tal modelo

representa um método de descoberta relativamente intuitivo, não tão rigoroso a ponto de com ele se chegar a resultados definitivos, mas também não tão vago a ponto de não se poder com ele operar significativamente projetando expectativas bastante definidas e comprováveis. Enfim, trata-se de um modelo com o qual se pode trabalhar concretamente tanto no ensino como na investigação (MARCUSCHI, 2001, p.74).

O modelo proposto por Marcuschi é dividido em nove operações, acrescidas de operações especiais e, de forma simplificada, dá conta dos aspectos textuais-discursivos envolvidos nas atividades de idealização (eliminação, completude e regularização) e nas atividades de reformulação (acréscimo, substituição e reordenação). Porém, o modelo não dá conta de fenômenos importantes como a compreensão ou as operações referentes ao tratamento dos turnos nos textos dialogados, lembrando, apenas, que as operações chamadas especiais estão envolvidas no que se refere aos turnos de fala.

Vale destacar que o autor não aponta o modelo como uma "representação de operações hierárquicas e sequenciadas, mas de operações que em certo sentido se dão preferencialmente nessa ordem, embora mescladamente" (MARCUSCHI, 2001, p.74).

O diagrama a seguir representa as operações textuais-discursivas da passagem do texto oral para o texto escrito propostas por Marcuschi (2001): 
Figura 4 - Operações de retextualização

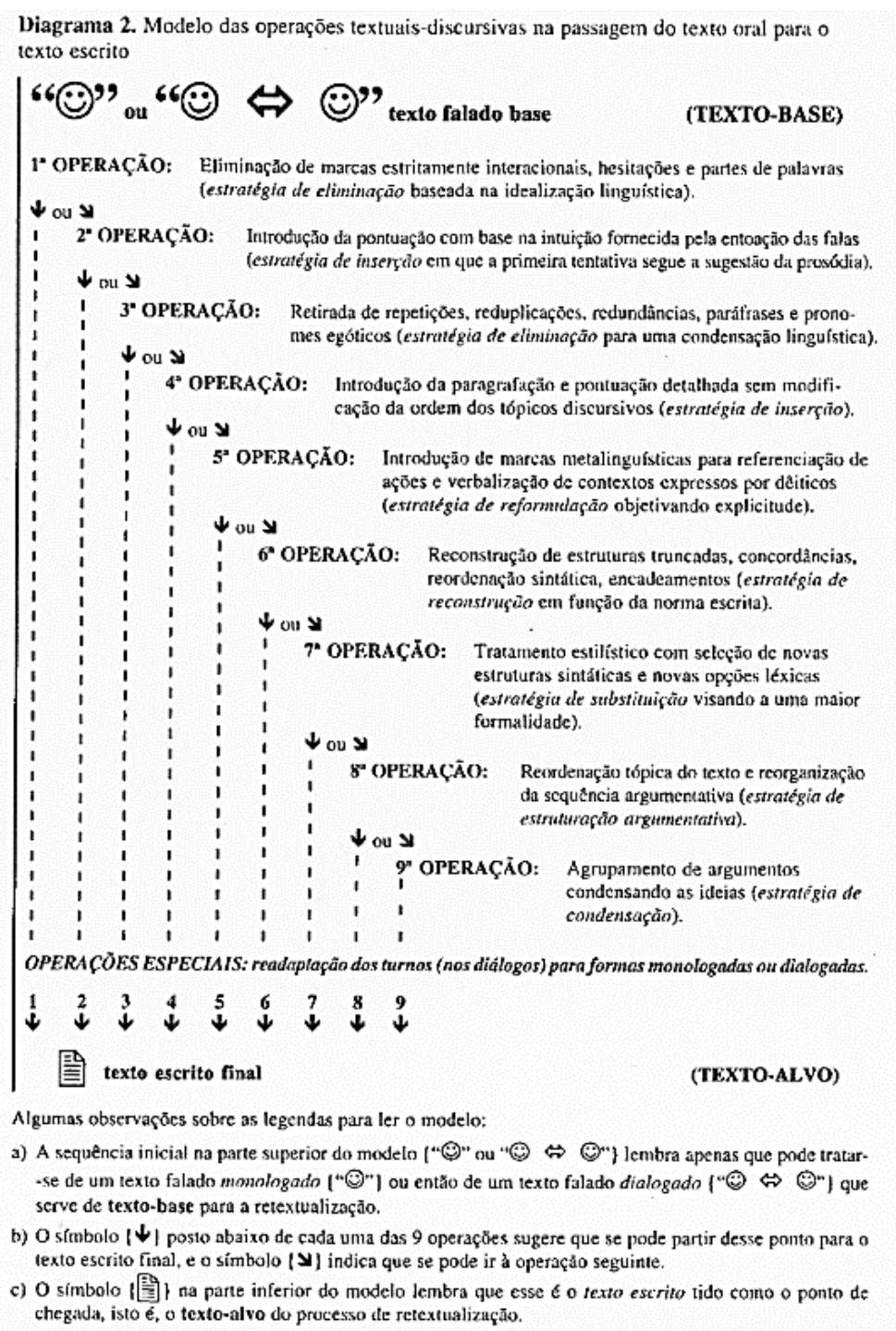

Fonte: Diagrama do modelo das operações textuais-discursivas na passagem do texto oral para o texto escrito (MARCUSCHI, 2001, p.75).

Em relação a tais operações, Marcuschi afirma que "a retextualização plena do texto falado (texto-base) em texto escrito (texto-alvo) deveria passar por todas as operações sugeridas, mas é possível que um indivíduo conclua sua atividade em qualquer ponto do processo" (MARCUSCHI, 2001, p.76). A seguir, trataremos, em linhas gerais, sobre cada uma das operações que podem estar envolvidas no processo de retextualização.

A primeira operação ocorre através de um processo imediato, com a eliminação de hesitações, de marcadores conversacionais, de segmentos de palavras iniciadas e não concluídas e de sobreposições. Ademais, nessa operação, são eliminadas as observações metalinguísticas sobre a situacionalidade ou sobre o fluxo da fala, como os comentários e ações dos falantes. De 
acordo com o autor, "tais eliminações não se referem à fala em si, mas à manipulação da transcrição" (MARCUSCHI, 2001, p.77).

Após a aplicação da primeira operação, a segunda operação tenta introduzir a pontuação diacrítica e formal, uma vez que a fala não possui tal recurso. Nas palavras do autor, tal procedimento deve-se ao fato do aparecimento de uma pontuação quase que espontânea por conta de fenômenos prosódicos, sendo também observada como a interpretação que o retextualizador pode fazer do texto-base.

$\mathrm{Na}$ terceira operação, temos a eliminação das repetições, muito comuns à fala, além das redundâncias informacionais e das reformulações parafrásticas. Junto a essas, temos as eliminações dos pronomes pessoais, principalmente os egóticos (marcados pela forma verbal de primeira pessoa). Ou seja, a operação consiste na retirada de elementos reduplicados.

A quarta operação dá continuidade a processos já iniciados anteriormente. Refere-se à paragrafação do texto e à pontuação aplicada de forma mais detalhada, sem a alteração na ordem dos tópicos discursivos.

As primeiras quatro operações são agrupadas pelo autor com o nome de operações de regularização e idealização; em suas palavras, "pela natureza das operações deste primeiro grupo e pela sua presença generalizada, parece que os fenômenos trabalhados baseiam-se em regularidades prosódicas e informacionais bastante estabilizadas" (MARCUSCHI, 2001, p.80).

Já as cinco operações seguintes são agrupadas como operações de transformação, pois dizem respeito a um tratamento da fala, de natureza sintática, semântica, pragmática e cognitiva, e não se pode observar separadamente como cada uma dessas estratégias é aplicada.

A operação cinco refere-se à introdução de marcadores de referenciação e de orientação espacial e temporal, como pronomes e dêiticos. Conforme Marcuschi (2001), vale ressaltar que

Há, no entanto, casos em que o gênero textual recebe uma estrutura que
permite a interpretação referencial, como nas cartas que têm, no cabeçalho,
uma data, um local de onde o missivista escreve e há alguém que assina. Tudo
isto permite entender pronomes do tipo "eu", ou dêiticos como "aqui",
"ontem", "amanhã" e outros que são lidos na relação com as coordenadas da
carta (MARCUSCHI, 2001, p.84).

Na sexta operação, estão envolvidas ações diversificadas e de grande importância em relação à normatização da escrita. Nela, há uma transformação dos enunciados com uma completa reordenação sintática e produção de enunciados diretos. 
As operações sete e oito estão relacionadas ao fenômeno cognitivo da interpretação presente na compreensão textual. Como aponta Marcuschi,

o tema da compreensão exigiria um modelo separado já que para transformar é necessário compreender o texto. Contudo, uma não compreensão não impede a retextualização, mas pode conduzir a uma transformação problemática, chegando ao falseamento (MARCUSCHI, 2001, p.86).

Enquanto a operação sete refere-se ao tratamento estilístico com a seleção de novas estruturas sintáticas e novas opções lexicais, a operação oito refere-se à reordenação tópica do texto e à reorganização da sequência argumentativa.

A nona operação aparece com estratégias significativas, a fim de diferenciar os processos de resumir e transformar. Para o autor, é necessário manter, na medida do possível, o mesmo volume de informação do texto-base para o texto-alvo. Dessa forma, um menor volume de texto se dá pela eliminação de elementos próprios da fala e não pela seleção de informações a fim de condensar o texto.

Por fim, as operações especiais referem-se ao tratamento dos turnos para o caso da retextualização de conversações. Tais operações envolvem três técnicas no tratamento dos turnos de fala, conforme o quadro a seguir:

Quadro 1 - Técnicas no tratamento dos turnos

\begin{tabular}{|l|l|}
\hline Técnica I: manutenção dos turnos & $\begin{array}{l}\text { Transposição dos turnos tal como } \\
\text { produzidos, abolindo as sopreposições e }\end{array}$ \\
& seguindo, no geral, as operações 1, 2, 3 e \\
5 do modelo, mas com uma sequenciação \\
por falantes, introduzindo segmentos \\
encadeadores a título de contextualização, \\
podendo haver fusão de turnos, sobretudo \\
os repetidos.
\end{tabular}


aplicando-se as operações 1 a 9 do modelo.

Fonte: Operações especiais envolvidas no tratamento dos turnos de fala nas atividades de retextualização (MARCUSCHI, 2001, p.89).

Vale ressaltar que, embora não haja uma etapa com foco nas operações de retextualização, para o desenvolvimento do presente projeto, demos mais importância às operações de idealização e reformulação $(1 \mathrm{a} 4)$ e às relacionadas à compreensão textual $(7,8$ e 9) e, também, às operações especiais, tendo em vista o uso do discurso reportado e a retextualização entre os gêneros textuais entrevista e reportagem.

\subsection{O DISCURSO CITADO NA CONSTRUÇÃO DO GÊNERO TEXTUAL REPORTAGEM}

Diversos documentos e perspectivas de ensino da língua, dentre os quais destacamos o viés de abordagem da análise linguística (conforme proposto por Mendonça, 2006), defendem a fluidez necessária entre texto e gramática no ensino de língua. A Base Nacional Comum Curricular (BNCC) elucida que as práticas leitoras compreendem dimensões inter-relacionadas às práticas de uso e reflexão no ensino da língua. Nesse contexto, ao se abordar a leitura de gêneros jornalísticos, como este trabalho se propõe a fazer, destacamos a importância do discurso citado como aspecto composicional do gênero. No item "Dialogia e relação entre textos", a BNCC aponta a importância de se levar o aluno a

Identificar e refletir sobre as diferentes perspectivas ou vozes presentes nos textos e sobre os efeitos de sentido do uso do discurso direto, indireto, indireto livre, citações etc (BRASIL, 2017, p.71).

No âmbito do dialogismo, Bakhtin (1990) defende que "o discurso citado é o discurso no discurso" (BAKHTIN, 1990, p.144), ou seja, é fazer uso do discurso do outro em nosso próprio discurso. Ainda de acordo com o autor, o discurso citado tem o conteúdo conservado, assim como sua "integridade linguística" e sua "autonomia estrutural primitiva".

Ainda sobre a relevância da abordagem dos diferentes discursos no ensino, destacamos que o uso do discurso citado aparece como uma das habilidades do objeto de conhecimento no eixo de leitura de textos do campo jornalístico/midiático para o $8^{\circ}$ ano do Ensino Fundamental. 
(EF89LP05) Analisar o efeito de sentido produzido pelo uso, em textos, de recurso a formas de apropriação textual (paráfrases, citações, discurso direto, indireto ou indireto livre) (BRASIL, 2017, p.175).

E no eixo Análise Linguística/Semiótica, ainda no estudo dos gêneros do campo jornalístico/midiático, a BNCC diz

(EF08LP14) Utilizar, ao produzir texto, recursos de coesão sequencial (articuladores) e referencial (léxica e pronominal), construções passivas e impessoais, discurso direto e indireto e outros recursos expressivos adequados ao gênero textual (BRASIL, 2017, p.189).

Nesse sentido, o documento reforça a importância do trabalho de análise linguística atrelado ao discurso citado em gêneros do campo jornalístico-midiático, o que nos propusemos a fazer na intervenção realizada.

No que concerne ao gênero textual reportagem, o uso do discurso citado deve ser observado, uma vez que contribui não só para o efeito de sentido que o autor objetiva para o seu texto, mas também para a credibilidade ou não da temática ou da informação veiculada.

O discurso citado pode apresentar-se no texto em três diferentes formatos: (1) o discurso direto, no qual há citação do discurso do outro; (2) discurso indireto, no qual há transposição do discurso do outro para o discurso do autor; e, (3) discurso indireto livre, no qual há a fusão entre os discursos do outro e do autor. Para a presente pesquisa e tendo em vista os gêneros jornalísticos abordados na intervenção, nosso estudo limitou-se à análise e reflexão, apenas, dos discursos direto e indireto.

Considerando-se que todo discurso manifesta outro(s) discurso(s), vale ressaltar que todo discurso é heterogêneo. Authier-Revuz (1990) indica que essa heterogeneidade apresentase em ordens distintas, tendo a heterogeneidade constitutiva do discurso e a heterogeneidade mostrada do discurso. Em nossa pesquisa, abordamos a segunda ordem citada, visto que esta é a que indica claramente a presença do discurso do outro no discurso do enunciador.

De acordo com Garcia (2009),

a heterogeneidade mostrada revela-se de forma explícita na materialidade textual. Ela, diferentemente da heterogeneidade constitutiva, é a indicação na superfície do texto da presença de outros discursos, de outras vozes que não a do locutor (GARCIA, 2009, p.4).

Segundo Authier-Revuz (1990), a heterogeneidade mostrada divide-se em marcada e não-marcada. Esta não provida de visibilidade, e aquela visível na materialidade-linguística. A primeira da ordem da enunciação e a segunda da ordem do discurso. Logo, a fim de limitar 
ainda mais o foco da intervenção aplicada, tratamos apenas da heterogeneidade mostrada marcada durante a intervenção.

Conforme aponta Garcia (2009), a heterogeneidade mostrada marcada cria mecanismos que, no discurso, distanciam o sujeito e aquilo que ele diz. Além disso, ela acontece "através de formas marcadas como o discurso direto, o discurso indireto, as aspas, o itálico e o metadiscurso do locutor" (GARCIA, 2009, p.4).

Como exposto acima, a citação em discurso direto e em discurso indireto apresentamse como modalidades da heterogeneidade mostrada, sendo a mais utilizada para marcar a presença de diferentes discursos nos textos jornalísticos, como o gênero textual reportagem.

Benites (2002) conceitua as duas modalidades de uso do discurso. Segundo o autor, o discurso indireto

não mantém estável, em sua globalidade, o conteúdo do discurso citado; ele é uma interpretação de um discurso anterior, não a sua reprodução. Por reconstruir, não uma sequência de palavras, mas o conteúdo proposicional de enunciado-fonte, o discurso indireto resulta na imbricação das palavras do sujeito que cita com as do sujeito-citado (BENITES, 2002, p.59).

Dessa maneira, o discurso indireto é a reprodução do discurso de outro através do discurso do locutor, ou seja, o discurso citado não é reproduzido fielmente, com a repetição de palavra por palavra, mas adaptado pelo autor tendo em vista sua compreensão e interpretação do discurso fonte.

Sobre o discurso direto, Benites (2002) aponta

no discurso direto predomina a repetição, a imitação. Esta é a razão porque o discurso direto autentica os enunciados reportados. Ela dá a segurança que decorre da ilusória sensação de exatidão das citações (BENITES, 2002, p.59$60)$.

Portanto, o discurso direto é a reprodução fiel do discurso fonte, mesmo que ilusória, uma vez que a enunciação não é a mesma que a do discurso original.

Vale salientar que Benites (2002) classifica a citação de diferentes formas a depender da intenção comunicativa do autor no texto produzido, bem como do efeito de sentido que ele deseja causar no leitor. Em outras palavras, o objetivo da classificação é reconhecer a "operação argumentativa que está por trás da incorporação da voz do outro no discurso em pauta" (BENITES, 2000, p.90).

De forma semelhante ao proposto por esses autores, vale destacar que, de acordo com a Gramática Normativa, o discurso citado pode apresentar-se em três diferentes modelos 
linguísticos (direto, indireto e indireto livre) que são tratados como categorias fechadas e estanques. A seguir, resenhamos um quadro com a descrição feita por Cunha e Cintra (1985) sobre o discurso citado.

Quadro 2: As características dos tipos de discurso na Gramática Normativa

\begin{tabular}{|c|c|c|}
\hline Estilo & Características linguísticas & Características semânticas \\
\hline $\begin{array}{l}\text { Direto: o narrador apenas } \\
\text { reproduz, fielmente, o que foi } \\
\text { dito pela personagem, ou } \\
\text { seja, a personagem expressa- } \\
\text { se por si mesma no texto. }\end{array}$ & $\begin{array}{l}\text { Marcado pelo uso dos verbos } \\
\text { dicendi e, na sua ausência, } \\
\text { pelos sinais gráficos de } \\
\text { pontuação (travessão, dois } \\
\text { pontos etc), indicando a fala } \\
\text { da personagem. }\end{array}$ & $\begin{array}{l}\text { Fazer emergir a personagem, } \\
\text { trazendo-a à vida para o } \\
\text { interlocutor, permitindo a } \\
\text { caracterização de sua atitude. }\end{array}$ \\
\hline $\begin{array}{l}\text { Indireto: } 0 \text { narrador } \\
\text { incorpora ao seu discurso a } \\
\text { fala da personagem, ou seja, } \\
\text { o narrador fala pela } \\
\text { personagem em seu texto, } \\
\text { reproduzindo o conteúdo, } \\
\text { mas não a forma. }\end{array}$ & $\begin{array}{l}\text { Uso dos verbos de elocução, } \\
\text { introduzindo a fala da } \\
\text { personagem através de uma } \\
\text { oração subordinada } \\
\text { substantiva desenvolvida ou } \\
\text { reduzida. }\end{array}$ & $\begin{array}{l}\text { Pressuposição de um relato } \\
\text { informativo, no qual o } \\
\text { diálogo é incorporado ao } \\
\text { discurso do narrador através } \\
\text { da subordinação semântico- } \\
\text { sintática. }\end{array}$ \\
\hline $\begin{array}{l}\text { Indireto livre: conciliação } \\
\text { entre o discurso direto e o } \\
\text { discurso indireto, ou seja, } \\
\text { narrador e personagem fama } \\
\text { em uníssono. }\end{array}$ & $\begin{array}{l}\text { No fator gramatical, temos a } \\
\text { liberdade sintática do } \\
\text { narrador e, no fator estético, } \\
\text { temos a adesão do narrador à } \\
\text { vida da personagem, } \\
\text { mantendo as características } \\
\text { do discurso direto, como } \\
\text { frases proferidas pela } \\
\text { personagem, interrogações e } \\
\text { exclamações feitas por ela, } \\
\text { bem como as características } \\
\text { do discurso indireto. }\end{array}$ & $\begin{array}{l}\text { Narrativa mais fluida e elo } \\
\text { psíquico entre narrador e } \\
\text { personagem. }\end{array}$ \\
\hline
\end{tabular}

Fonte: Baseado na obra de Cunha e Cintra (2001).

Observando a abordagem de Cunha e Cintra a abordagem (1985), percebemos que a Gramática Tradicional apresenta de forma superficial o uso do discurso citado, ressaltando 
apenas seu aspecto estrutural e seu uso nos textos narrativos ficcionais. Tal abordagem também é feita por outros autores como Rocha Lima (2011) e Bechara (2009). Rocha Lima (2011) limita-se a apontar as características linguísticas das três formas do discurso, bem como as mudanças que acontecem na transposição associada aos tempos verbais, de um formato a outro. Em um dos trechos, o autor escreve

Da transposição do estilo direto para o indireto, resultam alterações na estrutura do período, as quais se podem assim enumerar:

a) Terceira pessoa, em vez de primeira ou segunda.

b) Pretérito imperfeito, em vez de presente.

c) Futuro do pretérito, em vez de futuro do presente.

d) Subjuntivo, em vez de indicativo ou imperativo.

e) Forma declarativa, em vez de interrogativa ou imperativa.

f) Demonstrativo aquele, em vez de este ou esse.

(ROCHA LIMA, 2011, p.593).

Percebe-se que os autores citados acima preocupam-se apenas com as características linguísticas dos tipos de discurso, não fazendo nenhuma reflexão sobre seu uso e sua escolha por cada autor, a depender do seu objetivo comunicativo. Em outras palavras, há apenas a transmissão das características formais/estruturais de cada um dos tipos de discurso e de como pode ser feita a transposição de um tipo a outro.

Nas palavras de Silva e Barbosa (2016)

As análises linguísticas sobre o discurso citado em gramáticas, por exemplo, quer de natureza mais tradicional ou normativa, quer mais descritivas, propõem exercícios que exploram mais aspectos transformacionais entre os tipos de discurso citado, como por exemplo, mudar uma sentença que se encontra em discurso direto para uma construção indireta e vice-versa. Dedicam especial atenção às mudanças das formas verbais, dos pronomes empregados, de aspectos adverbiais e de sinais gráficos que delimitam as formas de citação (SILVA; BARBOSA, 2016, p.4).

Tal visão pode ser ampliada quando consideramos o discurso citado como reconstrução do discurso fonte, uma vez que nossos enunciados já remetem a enunciados anteriores, mesmo quando são modificados, já que se alteram a depender do gênero textual utilizado e da intenção comunicativa do texto. Como afirma Rojo (2014, s.n.), "um texto 'irrepetível', pois ainda que seja 'o mesmo', ou muito semelhante a um outro texto, estará enunciado em um novo contexto, o que modifica suas relações de sentido".

Acreditamos que uma gramática contextualizada e reflexiva deve observar não só os aspectos estruturais do discurso citado, mas também seu uso na abordagem dialógica da 
linguagem, considerando seus fatores de ordem social e histórica, além da intenção do locutor, assim como defendem Silva e Barbosa (2016):

A citação entra no discurso não apenas na estrutura morfossintática, mas na constituição de uma complexa relação de sentidos, pois são variadas as intenções comunicativas em se trazer um bloco enunciativo de outrem, mais ou menos detectável, a depender das características da citação (SILVA; BARBOSA, 2016, p.9-10)

Tal posicionamento também é defendido por Castro (2009), ao expor que

(...)poderíamos compreender melhor a nossa prática cotidiana, familiar e profissional de linguagem, analisar melhor a produção da imprensa e das mídias de um modo geral(...) (CASTRO, 2009, p.133).

Nesse sentido, percebemos que o conhecimento das características, do efeito da importância do discurso citado é crucial para a promoção da capacidade leitora de averiguar, refletir e analisar textos, uma vez que diferentes discursos são emparelhados na construção textual, questões essas que são ressaltadas na intervenção apresentada neste trabalho.

\subsection{A INCLUSÃO ESCOLAR: REFLEXÃO E SENSIBILIZAÇÃO}

A Constituição Federal garante o direito à educação a todo e qualquer cidadão, com o objetivo de proporcionar oportunidades iguais a todos. Considerando que há estudantes com necessidades especiais, a educação especial é uma das modalidades de ensino que visa ao aprimoramento de práticas pedagógicas para atender aos alunos com deficiência.

Segundo Silva, (2012),

Visando alcançar o desenvolvimento de uma escola democrática na qual a diversidade é respeitada e valorizada, o movimento de inclusão escolar prevê a revisão e a reformulação do sistema educacional como um todo, inclusive no que diz respeito às modificações na estrutura física dos prédios escolares (SILVA, 2012, p.10).

Nesse sentido, a inclusão escolar de alunos com deficiência como política educacional vem sendo implantada nas escolas desde a década de 90 e, com o passar dos anos, apesar de seu fortalecimento, continua apresentando desafios para todos aqueles que estão envolvidos. Como exemplos, podemos citar a formação docente insuficiente para atender a esses alunos, a 
falta de recursos humanos e financeiros nas escolas e a dificuldade na obtenção do real diagnóstico de vários estudantes.

Além disso, ainda nos deparamos com muitos obstáculos para a total inclusão e integração desses alunos nos diversos contextos sociais, principalmente, no espaço escolar, refletindo, muitas vezes, descaso e preconceito. A escola é um espaço com total responsabilidade na socialização dos alunos com deficiência juntamente com toda a comunidade escolar, pois é nela que as crianças começam a criar e estabelecer relações afetivas não só com o professor, mas também com os colegas. Portanto, o espaço escolar precisa ser acolhedor em todos os aspectos, fortalecendo os vínculos afetivos criados como um ponto positivo no desenvolvimento educacional desses alunos. De acordo com Mantoan (2015),

Se o que pretendemos é que a escola seja inclusiva, é urgente que seus planos se redefinam para uma educação voltada à cidadania global, plena, livre de preconceitos, que reconhece e valoriza as diferenças (MANTOAN, 2015, p.24).

Pensando nisso, é fundamental ver a escola como um espaço para a inclusão de todas as pessoas, garantindo uma educação com base no respeito da diversidade, considerando a forma como cada aluno aprende e tendo o professor como mediador tanto no processo de ensinoaprendizagem, quanto no estabelecimento desses vínculos afetivos em sala de aula, “onde todos possam conhecer o outro, passando a aceitá-lo e respeitá-lo com suas diferenças, costumes e necessidades" (SANTOS; MOURA, 2018, p.28).

Mantoan (2015), em sua obra Inclusão Escolar - O que é? Por quê? Como fazer?,ressalta que os termos integração e inclusão, ainda que tenham significados próximos, são utilizados em contextos diferentes e são baseados em divergentes posições teóricometodológicas. Nas palavras de Mantoan (2015),

O uso do vocábulo "integração" refere-se mais especificamente à inserção de alunos com deficiência nas escolas comuns, mas seu emprego dá-se também para designar alunos agrupados em escolas especiais para pessoas com deficiência, ou mesmo em classes especiais (se existentes), grupos de lazer ou residências para pessoas com deficiência (MANTOAN, 2015, p.26).

Já em relação à inclusão, a autora aponta que

O radicalismo da inclusão vem do fato de exigir uma mudança de paradigma educacional, à qual já nos referimos anteriormente. As escolas inclusivas atendem a todos os alunos sem discriminar, sem trabalhar à parte com alguns deles, sem estabelecer regras específicas para planejar, ensinar e avaliar alguns por meio de currículos adaptados, atividades diferenciadas, avaliação 
simplificada em seus objetivos. Pode-se, pois, imaginar o impacto da inclusão no sistema de ensino! (MANTOAN, 2015, p.28)

No que se refere ao objetivo da pesquisa, que se baseia na sensibilização e conscientização dos alunos não deficientes em relação aos alunos com deficiência, embora a autora sirva como aporte teórico em muitos momentos, tais definições de Mantoan não são suficientes para refletir nossa busca. Nesse sentido, adotamos a definição de inclusão dada por Aranha (2000), pois, nela, encontramos o significado mais próximo daquilo que foi proposto ao longo da pesquisa e da intervenção. De acordo com Aranha (2000),

a ideia de inclusão se fundamenta em uma filosofia que reconhece e aceita a diversidade na vida em sociedade. Isto significa garantia de acesso de todos, a todas as oportunidades, independente das peculiaridades de cada indivíduo ou grupo social (ARANHA, 2000, p.2).

Vale destacar que, embora na intervenção apresentada neste trabalho nosso objetivo tenha maior foco na inclusão como socialização, sabemos que tal conceito não se limita a isso. Esse objetivo justifica-se pelo cenário da intervenção durante sua aplicação: o ensino remoto como consequência da suspensão das aulas presenciais devido à pandemia da Covid-19. Logo, concordamos com Valle (2016), que diz:

um conceito de educação inclusiva deve ter como premissa a concepção da educação como direito de todos e não apenas da escola como lugar de permanência de todos, numa compreensão de que todos os alunos, enquanto seres singulares, têm características diferentes, pensam e aprendem de maneira diferente, e que todos têm direito à educação, independentemente de suas, condições sociais, necessidades educativas ou de seu credo (VALLE, 2016, p.25)

Conforme já explicitado, as circunstâncias de aplicação da intervenção fizeram com que o objetivo pensado inicialmente fosse reformulado, não sendo possível a contribuição para o desenvolvimento dos alunos com deficiência no processo de ensino-aprendizagem nos aspectos envolvidos na intervenção, uma vez que o ensino remoto apresenta desafios ainda maiores que o ensino presencial, como o acesso às ferramentas necessárias, por exemplo.

Tendo em vista o papel que os estudantes podem desempenhar no processo de inclusão dos alunos com deficiência, é essencial fazê-los refletir sobre o tipo de relacionamento que devem assumir com esses colegas, uma vez que "o afeto é o desígnio fundamental para o crescimento humano" (SANTOS; MOURA, 2018, p.30). De acordo com Santos e Moura (2018), 
Ao se vislumbrarem relações interpessoais em sala de aula, se pode imaginar como as interações e vínculos afetivos construídos entre crianças, professores e família podem ser mecanismos determinantes no desenvolvimento da aprendizagem do aluno quando a afetividade é condicionada a partir da criação de condições propícias para sua presença (SANTOS; MOURA, 2018, p.28).

Por fim, entendemos que o trabalho com a sensibilização e conscientização dos alunos não deficientes em relação ao acolhimento, ao acesso e ao respeito dos alunos com deficiência contribui para a formação cidadã dos estudantes e para a transformação do espaço escolar, minimizando o descaso, o preconceito e a exclusão desses discentes. 


\section{A METODOLOGIA DA PESQUISA-AÇÃO}

A interação entre professor e aluno e a qualidade do processo de aprendizagem são aspectos relevantes da didática da sala de aula que ganharam atenção especial a partir da década de 80. Bortoni-Ricardo (2008) argumenta que tais tendências despertaram nos professores a vontade de investigar o próprio trabalho com o intuito de visualizar a melhor maneira de inserir e acompanhar o desenvolvimento da aprendizagem de um aspecto em sala de aula.

Bortoni-Ricardo, assim como Engel (2000) e Tripp (2005), ressalta a importância de se alinhar teoria e prática no âmbito da Educação Básica. Nesse sentido, o Mestrado Profíssional em Letras tem contribuído, de forma significativa, para consolidar pesquisas que demonstram a prática de teorias já introduzidas há décadas por pesquisadores e incorporadas pelos documentos norteadores, como já mencionado anteriormente. Ao reduzir o espaço entre a teoria e a prática, o objetivo é traçar estratégias que possam ajudar, no contexto escolar, a melhorar o ensino da língua materna, por meio do conhecimento e da aplicação de estudos mais recentes sobre o ensino de LP. Nesse sentido, a pesquisa-ação mostra-se como uma metodologia compatível com o objetivo traçado pelo Mestrado Profissional de estreitar a teoria da academia com a prática de sala de aula. Para Engel (2000),

\footnotetext{
A pesquisa-ação é um tipo de pesquisa participante engajada, em oposição à pesquisa tradicional, que é considerada como "independente", "não-reativa" e "objetiva". Como o próprio nome já diz, a pesquise-ação procura unir a pesquisa à ação ou prática. É, portanto, uma maneira de se fazer pesquisa em situações em que também se é uma pessoa da prática e se deseja melhorar a compreensão desta (ENGEL, 2000, p.182).
}

Considerando-se que, no Mestrado Profissional, o estreitamento entre teoria e prática deve ocorrer de forma efetiva e que a aplicação de uma intervenção ocorre concomitantemente à pesquisa, a qual parte da observação de uma situação problema em sala de aula, a opção pelo uso da metodologia da pesquisa-ação mostra-se relevante nesse contexto. Nas palavras de Thiollent (2011), a pesquisa-ação é

um tipo de pesquisa social de base empírica que é concebida e realizada em estreita associação com uma ação ou com uma resolução de um problema coletivo e no qual os pesquisadores e os participantes representativos da situação ou do problema estão envolvidos de modo cooperativo ou participativo (THIOLLENT, 2011, p.20).

É importante frisar que, para iniciar uma pesquisa, o pesquisador precisa conhecer seus participantes, além do cenário no qual estão inseridos, pois é a partir de tais conhecimentos que 
surgirão os questionamentos que nortearão sua pesquisa. Assim, o ambiente, o público e o problema que serão investigados são únicos de cada pesquisador, e caberá a outros professores utilizarem essas pesquisas de acordo com sua sala de aula, adaptando-as. Nesse contexto, "é tarefa da pesquisa qualitativa em sala de aula construir e aperfeiçoar teorias sobre a organização social e cognitiva da vida em sala de aula, que é o contexto por excelência para a aprendizagem dos educandos" (BORTONI-RICARDO, 2008, p.42). Logo, é papel da pesquisa qualitativa a interpretação de fenômenos inseridos em um contexto, o interesse é no processo que acontece em um ambiente determinado e como os participantes envolvidos o interpretam.

As metodologias participativas como a pesquisa-ação emergiram da insatisfação com os métodos clássicos, já que os pesquisadores viram a necessidade de envolver os participantes da pesquisa na solução do problema em questão, atrelando, cada vez mais, teoria e prática nos processos de ensino e de aprendizagem. Esse fato é valorizado pela pesquisa-ação, uma vez que, nas palavras de Thiollent (2011),

Em muitos lugares, continuam prevalecendo as técnicas ditas convencionais
que são usadas de acordo com um padrão de observação positivista no qual se
manifesta uma grande preocupação em torno da quantificação de resultados
empíricos, em detrimento da busca de compreensão e de interação entre
pesquisadores e membros da situação investigada (THIOLLENT, 2011, p.13).

Cabe ressaltar que a pesquisa-ação não se constitui como uma metodologia com enfoque individual ou macrossocial. Ela é um instrumento voltado para o coletivo de pequenos grupos, encaixando-se no cenário escolar. Portanto, no contexto em que é aplicada, a pesquisaação leva em consideração fatores internos e externos que incidem sobre os participantes da pesquisa e sua realidade. Assim, seu objetivo não é apenas o levantamento de dados e a produção de relatórios, mas sim o desempenho de um papel ativo, por parte do pesquisador e dos participantes, para uma mudança do cenário dos fatos observados.

No caso da pesquisa no contexto escolar, muitas vezes, seu objetivo é voltado para a produção de conhecimento, principalmente, que seja útil não só para o espaço de investigação, mas também para que possa ser aplicado em diferentes salas de aula. Sendo assim, a pesquisaação poderá dar ênfase a três diferentes aspectos que são a resolução de problemas, a tomada de consciência e a produção de conhecimento. A respeito desses aspectos, Thiollent esclarece que

[...] a pesquisa-ação só consegue alcançar um ou outro desses três aspectos. Podemos imaginar que com maior amadurecimento metodológico, a pesquisa- 
ação, quando bem conduzida, poderá vir a alcançá-los simultaneamente (THIOLLENT, 2011, p.25).

No presente trabalho, a metodologia da pesquisa-ação foi conduzida na tentativa de, ao menos minimamente, atingir os três aspectos: a resolução do problema investigado, com a compreensão das nuances que envolvem o fenômeno linguístico em questão pelos participantes da pesquisa; a tomada de consciência, com os participantes chegando à conclusão do problema identificado e das formas utilizadas para sua resolução; e, por fim, a produção de conhecimento, o que pôde ser monitorado por mim, como professora-pesquisadora, em todo o tempo, e também por meio de instrumentos de pesquisa. Dessa forma, pode-se considerar que

[...] a pesquisa-ação não é constituída apenas pela ação ou pela participação. Com ela é necessário produzir conhecimentos, adquirir experiências, contribuir para a discussão ou fazer avançar o debate acerca das questões abordadas (THIOLLENT, 2011, p.28).

A pesquisa-ação possui características qualitativas, ou seja, não é um procedimento apenas quantitativo, pois visa a compreender a situação investigada, selecionando um problema para ser solucionado com a participação dos envolvidos. Como já vimos, a pesquisa-ação é uma metodologia para tratar de problemas coletivos e com ações também coletivas. Dessa forma, as ações que serão desenvolvidas e a forma como serão desenvolvidas poderão se modificar ao longo do processo, tornando-a um sistema aberto. Nas palavras de Toledo e Jacobi,

[...] a metodologia da pesquisa-ação é considerada um sistema aberto, isto porque diferentes rumos podem ser tomados no decorrer de seu desenvolvimento em função das demandas encontradas. Inicia-se, evidentemente com um planejamento (TOLEDO; JACOBI, 2013, p.159).

Dessa forma, ainda nas palavras de Toledo e Jacobi,

(...) ao destacar seu caráter reflexivo, mobilizador, gerador de conhecimentos interdisciplinares e de soluções coletivas, a pesquisa-ação aplicada à educação mostra-se com forte potencial de contribuição em processos de transformação das práticas institucionais, bem como no desenvolvimento da cidadania e do empoderamento, elementos essenciais para a mediação de situações de conflito (TOLEDO; JABOBI, 2013, p.166).

Nesse sentido, a pesquisa tem início com a exploração do cenário e dos participantes e é finalizada com a divulgação dos resultados obtidos, porém as etapas que compõem a intervenção serão adaptadas, modificadas e reestabelecidas a todo momento, levando em conta 
os eventos identificados ao longo do processo. No caso da pesquisa-ação, a ordem das etapas que compõem o trabalho não é fixa, com exceção da fase inicial (exploratória) e fase final (divulgação dos resultados), as outras fases planejadas se organizarão de acordo com o desenvolvimento da pesquisa.

O planejamento de uma pesquisa-ação é muito flexível. Contrariamente a outros tipos de pesquisa, não se segue uma série de fases rigidamente ordenadas. Há sempre um vaivém entre várias preocupações a serem adaptadas em função das circunstâncias e da dinâmica interna do grupo de pesquisadores no seu relacionamento $\mathrm{com}$ a situação investigada (THIOLLENT, 2011, p.55).

Ainda sobre a flexibilização do planejamento da pesquisa e das etapas previstas para a intervenção, Costa-Hübes e Simioni (2014) salientam:

É no transcorrer das aulas que o planejamento realmente se efetiva, haja vista a realidade que se evidencia a partir dos questionamentos, das dúvidas, do (des)conhecimento dos alunos. Por isso, o plano de aula do professor precisa ser flexível para que, à medida que perceber a urgência de modificações, elas possam ser efetivadas (COSTA-HÜBES; SIMIONI, 2014, p.22).

O projeto de pesquisa teve como metodologia a pesquisa etnográfica colaborativa, visto que sua proposta se relaciona ao que se deseja promover: "[...] a pesquisa etnográfica colaborativa tem por objetivo não apenas descrever, como no caso da etnografia convencional, mas também promover mudanças no ambiente pesquisado" (BORTONI-RICARDO, 2008, p.71). Nesse caso, não só o professor-pesquisador, mas também os outros participantes da pesquisa, os alunos, não desempenham um papel passivo, já que são ativos na construção e na transformação do conhecimento, agindo como coparticipantes na pesquisa. De acordo com Bortoni-Ricardo (2008),

$\mathrm{Na}$ pesquisa etnográfica - ao contrário de pesquisas que seguem outras metodologias, ou mesmo, outros paradigmas -, não há uma divisão rígida entre a fase inicial de observação para coleta de dados e a fase de análise. A pesquisa tem sempre caráter interpretativo e se inicia com algumas perguntas exploratórias, postuladas com base na leitura da literatura especializada, na experiência de vida e no senso comum do pesquisador (BORTONIRICARDO, 2008, p.72).

Além da etnografia colaborativa, a pesquisa-ação, como já antecipado, também norteou a metodologia dessa pesquisa. Ambas as concepções buscam muito mais do que quantificar o(s) problema(s) detectado(s) pela pesquisa, mas também modificar o ambiente no 
qual a pesquisa acontece, assim como seus participantes. Engel (2000) ressalta a pesquisa-ação como "um instrumento valioso, ao qual os professores podem recorrer com o intuito de melhorarem o processo de ensino-aprendizagem, pelo menos no ambiente em que atuam" (ENGEL, 2000, p.189).

Nesta pesquisa, foram utilizados como instrumentos de análise qualitativa uma conversa com a docente da turma no ano anterior e uma roda de conversa com os alunos sobre os temas de que gostam (fase exploratória). Ademais, foi feita análise qualitativa e quantitativa das produções inicial (diagnóstico) e final (resultado) dos alunos, bem como uma constante análise qualitativa ao longo dos módulos da intervenção.

\subsection{LÓCUS DA PESQUISA E SUJEITOS ENVOLVIDOS}

Conforme já explicitado, a pesquisa-ação, por se tratar de uma metodologia colaborativa, contará com 5 alunos participantes ${ }^{2}$. No trabalho em questão, além da professora pesquisadora Thamiris Alvim de Souza, orientada pela professora Dra. Natália Sathler Sigiliano, os alunos também desempenharam papel fundamental para o desenvolvimento da pesquisa.

A intervenção começou a ser aplicada em uma turma de oitavo ano do turno vespertino da Escola Estadual Engenheiro Henrique Dumont, doravante denominada Polivalente, situada na cidade de Santos Dumont, em Minas Gerais. A turma é denominada $8^{\circ}$ (Castro Alves) e é composta por 33 alunos, sendo 3 alunos atendidos pela Sala de Recursos por necessitarem de Atendimento Educacional Especializado.

A escola Polivalente atende alunos de diversos bairros da cidade de Santos Dumont, incluindo parte da Zona Rural do município. O corpo discente tem perfil econômico variado, mas, em sua maioria, é proveniente de comunidades carentes. São atendidos cerca de 700 alunos, nas modalidades de Ensino Fundamental II, Ensino Médio, Ensino Médio Integral Integrado, Educação de Jovens e Adultos e Educação Profisssional.

Devido à pandemia da Covid-19 e, consequentemente, ao decreto de suspensão das aulas no estado de Minas Gerais, não temos um perfil mais detalhado da turma, visto que tivemos, praticamente, um mês de aula presencial. Durante a suspensão das aulas na modalidade presencial, as aulas das escolas públicas do estado de Minas Gerais retornaram de forma remota, desde 13 de maio de 2020. Os alunos assistiram às videoaulas pela Rede Minas, também

\footnotetext{
${ }^{2}$ Todos os alunos participantes assinaram o termo de consentimento para fazer parte desta pesquisa, aprovada pelo Cômite de Ética da UFJF.
} 
disponíveis na página da Rede Minas no YouTube e no aplicativo Conexão Escola (disponibilizado pelo Estado). Além disso, receberam apostilas chamadas Plano de Estudos Tutorado (PET) com atividades que foram realizadas e enviadas aos seus respectivos professores. Nós, professores, atuamos como tutores das atividades, atendendo aos alunos através das redes sociais não institucionais (Whatsapp, Facebook, Instagram), do e-mail e do chat no aplicativo Conexão Escola. Embora esse atendimento tenha acontecido, não foi suficiente para que um perfil mais detalhado da turma fosse traçado, já que o contato não pôde ser estabelecido com todos os alunos, visto que alguns receberam as apostilas pelo correio por não terem acesso à internet.

O ano letivo de 2020 teve seu formato presencial alterado com a suspensão das aulas devido à pandemia da Covid-19. As aulas na rede pública estadual de Minas Gerais ficaram suspensas por dois meses, entre 18/03/2020 até 17/05/2020, e retornaram de forma remota a partir de 18/05/2020, com o encerramento do ano letivo em 30/01/2021, ainda na modalidade do ensino remoto. Dessa forma, o lócus da pesquisa inicial sofreu grandes transformações, modificando o cenário de aplicação em vários aspectos, pois, notando que o ensino presencial não seria retomado de forma imediata, optou-se pela tentativa de aplicação remota. Como o Estado de Minas Gerais instituiu a realização do PET para o cumprimento da carga horária, a intervenção não pôde ser aplicada, de forma obrigatória, como parte dela. Portanto, a alternativa que encontramos foi de convidar os alunos da turma $8^{\circ}$ ano CA para que participassem da realização de aulas e atividades extras. O convite foi feito de forma individual a cada aluno e também no grupo de Whatsapp da turma, e, depois de muita conversa, 5 alunos se interessaram em participar da intervenção. Sabemos que, proporcionalmente à quantidade de alunos que temos em salas de aula tradicional, esse não é o número ideal, porém, de acordo com o que se propõe a ser um Programa de Mestrado Profissional em Letras, a aplicação da intervenção, ainda que com poucos estudantes, fez muito mais sentido para a professora pesquisadora e colaborou substancialmente para sua formação e dos estudantes envolvidos. Nesse caso, pude observar minha prática e reformulá-la sempre que necessário, coletei dados e os analisei para a pesquisa e, o mais importante, pude contribuir de forma mais direta com a formação daqueles alunos que quiseram participar desta pesquisa.

Como já mencionado, 5 alunos participaram das etapas posteriores ao diagnóstico feito. Apesar do número reduzido, o perfil desses alunos era bem heterogêneo, levando em consideração o nível social, o comportamento, o interesse, a participação e outros aspectos. Todos são alunos da série regular, ou seja, de acordo com sua faixa etária, sendo 3 meninas e 2 meninos. A intervenção foi retomada em 21 de setembro de 2020 com aulas através da 
plataforma Zoom, um serviço gratuito de conferência remota que possibilita o compartilhamento de tela, além do uso de ferramentas como o WhatsApp, o Gmail, o Google Sala de Aula, o Google Formulário e o Google Drive. Antes do início da intervenção, na semana de 14 de setembro, os alunos foram orientados em relação às ferramentas que seriam utilizadas. Vale ressaltar que quase todos os alunos participantes tinham acesso à internet, ao computador ou celular com microfone e câmera, com exceção de um dos alunos que não possuía a câmera, apenas o microfone.

Os encontros aconteciam em média 3 vezes por semana, tentando, ao máximo, manter o tempo de aula que teriam de forma presencial, logo, ao longo da semana tínhamos 5 aulas síncronas de 45 minutos, sendo 2 aulas às segundas, 2 aulas às terças e 1 aula na quarta. Havia um horário previamente fixado para as aulas, mas era flexível, caso houvesse qualquer pedido dos alunos. Além disso, muitas aulas foram mais longas do que o inicialmente acordado, seja para finalizar uma atividade, seja para atender as demandas dos alunos referentes a outras atividades da escola durante o ensino remoto. A grande maioria das atividades da intervenção foram realizadas durante os encontros virtuais, sendo poucas as vezes em que houve tarefas para casa. Esse formato permitiu uma análise qualitativa mais fiel, além de poder substituir os PET's, com autorização da equipe gestora da escola, e ser usada para contabilizar a carga horária do ano letivo de 2020 dos alunos que participaram da intervenção. Todos foram bastante frequentes durante toda a intervenção e as ausências, quando ocorreram, foram sempre justificadas.

\subsection{A INTERVENÇÃO EM SALA DE AULA}

Para melhor organização e visualização das etapas da sequência didática, serão apresentados os tópicos aplicados em sala de aula presencial e em sala de aula remota, conforme o quadro 2. Em seguida, as etapas serão descritas e analisadas.

Quadro 3 - Etapas da Intervenção

\begin{tabular}{|l|l|}
\hline Pré-intervenção: Conhecendo a turma & - Conversa da professora pesquisadora com \\
& a professora do ano de 2019 sobre o perfil \\
da turma; & - Primeiros contatos com a turma: \\
& reconhecimento; \\
& - Roda de conversa com os alunos sobre \\
& quais são os temas que lhes interessam; \\
\hline
\end{tabular}




\begin{tabular}{|c|c|}
\hline & $\begin{array}{l}\text { - Produção do parágrafo com a justificativa } \\
\text { para os temas escolhidos. }\end{array}$ \\
\hline $\begin{array}{l}1^{\text {a }} \text { etapa: Observando os gêneros textuais } \\
\text { entrevista escrita e reportagem para a } \\
\text { produção inicial }\end{array}$ & $\begin{array}{l}\text { - Módulo 1: Entrevista; } \\
\text { - Módulo 2: Reportagem; } \\
\text { - Módulo 3: Reconhecendo a reportagem } \\
\text { nos suportes jornal e revista impressos; } \\
\text { - Módulo 4: Aplicação da Produção } \\
\text { Diagnóstica do gênero textual reportagem } \\
\text { (Produção Inicial). }\end{array}$ \\
\hline $\begin{array}{l}2^{\mathrm{a}} \text { etapa: Ambientação e primeiras } \\
\text { reflexões sobre a temática da Inclusão } \\
\text { Escolar }\end{array}$ & $\begin{array}{l}\text { - Módulo 1: Ambientação; } \\
\text { - Módulo 2: Reflexão e Sensibilização; } \\
\text { - Módulo 3: Coleta de informações; } \\
\text { - Módulo 4: Da temática ao gênero } \\
\text { entrevista. }\end{array}$ \\
\hline $\begin{array}{l}3^{\text {a }} \text { etapa: Gênero Textual Entrevista: um } \\
\text { passeio entre as modalidades oral e escrita }\end{array}$ & $\begin{array}{l}\text { - Módulo 1: Reconhecimento do gênero } \\
\text { entrevista na modalidade escrita; } \\
\text { - Módulo 2: A entrevista na modalidade } \\
\text { oral; } \\
\text { - Módulo 3: A entrevista - o processo de } \\
\text { retextualização da modalidade oral para a } \\
\text { modalidade escrita. }\end{array}$ \\
\hline $4^{\mathrm{a}}$ etapa: Gênero Textual Reportagem & $\begin{array}{l}\text { - Módulo 1: Reconhecimento do gênero } \\
\text { textual reportagem; } \\
\text { - Módulo 2: Estrutura e características do } \\
\text { gênero reportagem; } \\
\text { - Módulo 3: Comparação entre textos - } \\
\text { diferentes reportagens; } \\
\text { - Módulo 4: Um passeio entre modalidades } \\
\text { - da reportagem oral para a reportagem } \\
\text { escrita, no processo de retextualização. }\end{array}$ \\
\hline $\begin{array}{l}5^{\mathrm{a}} \text { etapa: } \mathrm{O} \text { discurso citado no gênero } \\
\text { textual reportagem na modalidade escrita }\end{array}$ & $\begin{array}{l}\text { - Módulo 1: As vozes presentes no texto; } \\
\text { - Módulo 2: Os discursos direto e indireto; } \\
\text { - Módulo 3: A transposição dos tipos de } \\
\text { discurso. }\end{array}$ \\
\hline $\begin{array}{l}6^{\mathrm{a}} \text { etapa: Colocando os conhecimentos em } \\
\text { prática }\end{array}$ & $\begin{array}{l}\text { Aplicação da Produção Final: } \\
\text { Retextualizando o gênero entrevista para o } \\
\text { gênero reportagem. }\end{array}$ \\
\hline
\end{tabular}

Fonte: Autoria própria (2020).

A pré-intervenção constituiu-se do conhecimento da turma, desde a conversa com a docente de língua portuguesa do ano de 2019 até a aplicação da produção diagnóstica inicial. Primeiramente, foram levantados alguns dados com a professora do ano de 2019 sobre o perfil da turma, e alguns deles foram confirmados nas primeiras semanas do ano letivo de 2020, com os primeiros contatos com a turma, por exemplo, o fato de a turma ser bem heterogênea em relação à disciplina dentro de sala, ao interesse nas aulas e à responsabilidade com as tarefas e, 
consequentemente, com o estudo. A partir disso, desenvolveu-se uma roda de conversa com os alunos, que teve como objetivo saber sobre os assuntos de que gostavam e despertar ideias sobre a forma como eles poderiam ser trabalhados nas aulas de língua portuguesa. Durante a roda de conversa, os alunos citaram como temáticas os jogos on-line e games (tema que guiou a etapa diagnóstica), esportes, curiosidades sobre a língua portuguesa, além de vários temas relacionados, de certa forma, à empatia, como preconceito, racismo, feminismo e bullying. Em seguida, foi pedido aos alunos que elaborassem, em grupos, um parágrafo escrito que justificasse a escolha de tais temas para serem abordados ao longo das aulas de LP. O fato de apontarem tantos temas que estão centrados no olhar da sociedade para o próximo reforçou a escolha da inclusão de alunos com deficiência como temática transversal à pesquisa. Após a roda de conversa e a produção dos parágrafos, 7 aulas foram destinadas à aplicação de atividades da primeira etapa, relacionadas aos gêneros usados para a produção inicial. E, finalizando esta etapa, uma chamada de produção foi elaborada pela professora-pesquisadora, contendo o gênero textual que seria produzido, o público-alvo, o suporte em que o texto seria publicado e o objetivo da produção de tal texto. Para a aplicação desta primeira produção de caráter diagnóstico, foram trabalhados, através de projeções, dois textos modelares, uma entrevista e uma reportagem, mas apenas questões de compreensão foram exploradas, ou seja, aspectos estruturais dos gêneros não foram trabalhados nesse momento. O objetivo dessa produção foi levantar o conhecimento prévio que os alunos tinham sobre o gênero reportagem, quais eram os conhecimentos ou não que apresentavam em relação à estrutura do gênero e quais características gramaticais atinentes à estruturação do gênero, pertinentes à reportagem, seriam relevantes de serem destacados nesta pesquisa-ação.

A segunda etapa teve o objetivo de introduzir a temática da inclusão de pessoas com deficiência nos diversos contextos sociais, principalmente, no espaço escolar e levar os alunos a refletir sobre a educação especial e inclusiva. A ideia inicial dessa etapa era uma dinâmica proposta para que os alunos, em duplas, estivessem, através de simulação, no lugar de alguém que é portador de alguma deficiência e também no papel de uma pessoa que os auxiliasse. Ao longo da dinâmica, tais papéis iriam se inverter, para que todos passassem por toda a experiência. Após a realização da dinâmica, os alunos responderiam um questionário com perguntas que teriam o objetivo de apresentar dados que demonstrassem a sensação de passar pela experiência, os sentimentos que foram despertados ao longo da atividade e as reflexões acerca do tema. Por fim, uma roda de conversa seria feita com os alunos, a professorapesquisadora e uma professora bidocente, com o intuito de compartilhar as experiências vividas e saber mais sobre a educação especial e inclusiva na escola. 
Infelizmente, devido à necessidade do ensino remoto e do novo lócus de pesquisa, toda essa etapa precisou ser reelaborada. Assim, foi preciso reestruturar a proposta, pensando em novas maneiras de realizar tal ambientação e sensibilização dos alunos participantes com a temática da inclusão de alunos com deficiência. Dessa forma, diferentes gêneros textuais, como videoanimações e HQ's, cujos temas abordados eram relacionados à inclusão de pessoas com deficiência, foram utilizados durante a etapa, assim como muitas conversas entre a professora pesquisadora e os alunos com o intuito de compartilhar informações e experiências sobre o assunto, além de proporcionar a reflexão sobre o nosso papel para que a inclusão seja verdadeiramente concretizada. Por fim, a aplicação de um formulário permitiu que observássemos as percepções dos alunos quanto ao tema discutido ao longo da segunda etapa.

As etapas 3 e 4 foram elaboradas com ênfase na abordagem dos dois gêneros textuais da pesquisa: a entrevista e a reportagem. Nessas etapas, os alunos tiveram contato com textos modelares dos respectivos gêneros, bem como observaram e refletiram sobre suas estruturas prototípicas e suas características linguísticas. Além disso, o processo de retextualização, tão caro à pesquisa, sendo um dos aspectos observados na análise da produção final, foi realizado em ambas as etapas. Ressaltamos que, nesse momento, o foco do processo limitou-se, apenas, à retextualização entre modalidades, ou seja, da entrevista oral para a entrevista escrita e da reportagem oral para a reportagem escrita. O objetivo dessas etapas foi observar o ganho no processo de aprendizagem dos alunos quanto à construção dos gêneros em questão e à para a modalidade escrita, com foco nas operações de retextualização e na forma como inserem o discurso reportado. A avaliação desses aspectos auxiliou na elaboração das atividades da etapa seguinte.

A etapa 5 foi elaborada dando maior importância à questão do discurso citado e sua relevância para a construção da reportagem, abordando reflexões quanto às formas como esse discurso pode ser realizado na produção do gênero textual reportagem (discurso direto/citação e/ou discurso indireto). O objetivo dessa etapa foi a observação da presença de outros discursos na reportagem, das características estruturais de sua construção, uso dos verbos dicendi e de elocução, escolha dos verbos utilizados e motivação para a escolha de uso dos discursos direto e indireto, dos efeitos de sentido na escolha do tipo de discurso a ser utilizado e se sua relevância para a credibilidade do texto.

Por fim, a última etapa da intervenção se constituiu na chamada de produção final. Nessa etapa, mais uma vez, os alunos produziram uma reportagem, mas, diferente do que ocorreu na produção inicial cuja temática foi o criador do videogame, a temática abordada foi a inclusão de alunos com deficiência no espaço escolar. A retextualização proposta na última 
etapa da intervenção foi a produção de uma reportagem com o uso de diferentes textos-base, que foram os textos utilizados ao longo da intervenção, mais as entrevistas feitas pelos próprios alunos na Etapa 3/Módulo 3, além de textos pesquisados por eles, caso julgassem necessário. $\mathrm{Na}$ produção final, observamos a construção do gênero reportagem (estrutura e características) e o uso dos discursos presentes nos textos-base na construção do gênero textual reportagem. A chamada de produção refletiu uma situação real de circulação, culminando na publicação de uma matéria sobre a Pesquisa e Intervenção realizada, em um jornal on-line do município de Santos Dumont, o Jornal Mensagem, no qual trechos dos textos dos alunos foram publicados com o intuito de mostrar aos leitores do jornal as percepções dos alunos acerca da inclusão de alunos com deficiência nas escolas.

\subsection{INSTRUMENTOS DE ANÁLISE PARA COMPOSIÇÃO DOS MÓDULOS DA INTERVENÇÃO E PARA A PESQUISA}

Nesta pesquisa-ação, como já apresentado, a sala de aula presencial e remota foi alvo de análise qualitativa constante, a fim de que as estratégias didáticas elaboradas fossem estruturadas e reestruturadas sempre que necessário. Como já explicitado, o planejamento da intervenção teve início antes mesmo de, como professora pesquisadora, eu ter tido contato direto com a turma. Por meio do diálogo com a docente da turma no ano de 2019, foi ressaltado que a turma apresentaria vulnerabilidades em relação à consolidação de aprendizagem de LP, principalmente, no que diz respeito à compreensão textual. Isso também se refletia na compreensão dos fenômenos linguísticos, visto que, de acordo com a docente, muitas vezes, o texto era trabalhado de forma separada da gramática. Além disso, foi relatado o perfil disciplinar e de interesse da turma, em que se pontuou a questão da formação de grupos com alunos de comportamentos semelhantes, grupos de afinidade. Todas as informações colhidas com a professora regente da turma em 2019 foram confirmadas através do breve contato presencial que tive com os alunos entre os meses de fevereiro e março de 2020. Apesar do curto espaço de tempo, foi perceptível a divisão espacial da turma dentro de sala de aula por conta não só dos grupos de afinidades já formados, mas também por comportamento e interesse semelhantes nas aulas. Como relatado pela professora da turma no ano de 2019, os alunos demonstraram dificuldades no que se refere à compreensão textual relativas à localização de informações e a inferências.

Posteriormente, uma roda de conversa permitiu levantar dados sobre temáticas que os atraíam. A roda de conversa foi um instrumento importante uma vez que auxiliou na 
estruturação das atividades iniciais da intervenção e produção inicial (etapa diagnóstica) de forma a promover o engajamento maior dos alunos, e, também, reforçou minha escolha da temática que perpassa toda a pesquisa - a inclusão de alunos com deficiência. Neste momento, também pude perceber a dificuldade que os alunos apresentaram no processo de transformar o que foi discutido durante a roda de conversa em um texto escrito, o que se tornou uma das motivações para a elaboração da chamada de produção inicial, cujo um dos intuitos foi de desenvolver habilidades atreladas à retextualização. Também foi utilizado, como instrumento de análise, o formulário aplicado na Etapa 2/Módulo 3, no qual os alunos puderam externar opiniões e experiências em relação à inclusão de pessoas com deficiência.

Nesse contexto e, ainda, assumindo-se os princípios da SD, a pesquisa apresenta como instrumento para a elaboração dos módulos e observação do desenvolvimento dos alunos a análise qualitativa e quantitativa de produção inicial e a análise qualitativa da produção final. Para tanto, as produções foram analisadas com relação à estrutura do gênero textual reportagem (manchete, subtítulo, lide, pessoa do discurso e coesão), havendo destaque quanto ao uso do discurso citado (uso do verbo dicendi, uso do discurso direto, uso do discurso indireto e pontuação no uso do discurso citado).

Vale destacar que, durante toda a intervenção, como professora pesquisadora, observei a realização de cada uma das etapas e propus novas atividades e módulos quando julguei ser necessária sua inclusão. Na próxima seção, serão apresentadas descrições e análises de algumas atividades de cada uma das etapas. 


\section{DESCRIÇÃO E ANÁLISE DA INTERVENÇÃO EM SALA DE AULA}

Conforme apresentado anteriormente, a intervenção em sala de aula foi composta pela pré-intervenção: Conhecendo a turma; e por seis etapas: Observando os gêneros textuais entrevista escrita e reportagem para a produção inicial; Ambientação e primeiras reflexões sobre a temática da Inclusão Escolar; Gênero textual entrevista: um passeio entre as modalidades oral e escrita; Gênero textual reportagem; O discurso citado no gênero textual reportagem na modalidade escrita e Colocando os conhecimentos em prática. Vale ressaltar que a temática da inclusão de alunos com deficiência, com o objetivo de sensibilizar e conscientizar os alunos sobre a importância da inclusão, foi abordada ao longo da maior parte das etapas da intervenção, com exceção da etapa 1, na qual a temática utilizada foi o videogame, uma vez que esse foi um dos assuntos abordados pelos alunos na roda de conversa, sendo utilizado, em um primeiro momento, como uma forma de engajar os alunos no processo de intervenção. A seguir, serão descritas e analisadas as etapas que constituíram a pesquisa interventiva.

\subsection{PRÉ-INTERVENÇÃO: CONHECENDO A TURMA}

A análise prévia da turma, com finalidade de planejamento inicial da intervenção, ocorreu antes do início do ano letivo de 2020, assim que tomei conhecimento das turmas em que iria ministrar aulas, oportunidade em que pude optar pela turma de $8^{\circ}$ ano como aquela que participaria da intervenção. Em conversas com a docente na turma no ano de 2019, buscando saber mais sobre o lócus que encontraria e sobre o contexto em que meus alunos estão inseridos, tomei ciência de algumas dificuldades que os alunos enfrentam em relação ao aprendizado de LP e do perfil deles quanto à disciplina e ao interesse nas aulas. Através dessa conversa, foi relatado que os alunos da turma em que o projeto foi aplicado apresentavam dificuldades em relação à compreensão textual, interferindo no estudo de fenômenos linguísticos, pois teriam dificuldade de relacionar o estudo de gramática ao uso real, por meio dos gêneros textuais. Entretanto, pela conversa, pude entender que, nas aulas, a gramática estudada era sempre dissociada do texto no qual está inserida, certamente levando os alunos a decorar conceitos e classificações ao invés de construir os conhecimentos de forma aplicada a usos efetivos. Portanto, as aulas eram moldadas de acordo com o ensino tradicional, ou seja, de forma transmissiva. Além disso, nessa conversa, pude observar que o texto, embora fosse sempre utilizado nas aulas da professora do ano de 2019, parecia não ocupar o papel central no ensino, visto que havia separação das aulas de leitura e compreensão das aulas de gramática. Outro 
aspecto destacado durante a conversa com a docente do ano de 2019 foi o fato de que havia nítida formação de grupos na turma, o que se delimita ao interesse e à participação nas aulas, ou seja, aqueles alunos mais participativos e com melhor rendimento estavam sempre juntos, assim como se juntavam com frequência aqueles que não demonstravam tanto interesse nas aulas. Essa conversa contribuiu para uma percepção preliminar da turma em que a intervenção seria aplicada, guiando o início da intervenção de modo a traçar diferentes estratégias de abordagem com a turma no início do ano letivo de 2020, para que a relação estabelecida fosse de cooperação e maior participação.

O módulo seguinte, "Primeiros contatos com a turma", aconteceu nas primeiras semanas do ano letivo de 2020. Nesse módulo, objetivava-se observar se o que foi dito em relação à turma seria confirmado, além de formular minhas próprias percepções sobre ela. $\mathrm{O}$ maior objetivo desse módulo era estreitar o meu relacionamento com a turma e conhecer um pouco mais do contexto em que esses alunos estão inseridos para que eu conseguisse propor uma intervenção que, de fato, fosse válida para os estudantes naquele contexto. A execução desse módulo foi baseada na observação desses alunos em relação ao seu comportamento, ao relacionamento interpessoal e ao interesse e atenção nas aulas. Nesse momento, muito do que foi levantado no módulo anterior foi confirmado. Percebi que, além da divisão apontada pela professora do ano de 2019, a turma também era dividida em grupos bem delimitados, embora não houvesse conflitos marcantes entre eles. Ou seja, dentre os mais participativos havia pequenos grupos, assim como dentre os menos participativos também havia. Tais grupos eram formados por diferentes motivos, como aqueles que estudavam juntos por mais tempo, aqueles que moravam perto uns dos outros ou ainda aqueles que tinham interesses parecidos. Além disso, ficou claro, pelas minhas observações, que alguns alunos demonstravam muito mais interesse nas aulas que outros. Esse fato também foi confirmado posteriormente pelo pequeno número de alunos (apenas 5) que se interessaram em participar voluntariamente da intervenção.

Durante a aplicação desse módulo, ainda na modalidade de aulas presenciais, a turma era composta por 38 alunos. Vale ressaltar que, nesse momento, o sistema da Secretaria de Educação do Estado (SEE) ainda não havia realizado a enturmação desses alunos, por isso a quantidade de alunos na turma foi alterada posteriormente.

O terceiro módulo, intitulado Roda de Conversa, cujo intuito era saber mais sobre os assuntos dos quais os alunos gostam e, consequentemente, conhecê-los melhor foi uma atividade despretensiosa, com o único objetivo de ouvir o que os alunos gostavam e criar laços que permitissem conhecê-los melhor, o que poderia ajudar na percepção de temáticas interessantes a serem abordadas durante a intervenção. Entretanto, apesar de ter sido uma etapa 
não tão planejada por mim, após algumas observações feitas neste módulo, a problemática a ser investigada foi delimitada, baseada não só nas aulas já ministradas no início do ano letivo de 2020 e nos participantes da pesquisa, mas também na roda de conversa em questão. Thiollent (2011) aponta que a fase exploratória da pesquisa é imprevisível devido à sua diversidade de situações e que, desse modo, "é impossível enunciarmos regras precisas para organizar os estudos da fase exploratória" (THIOLLENT, 2011, p.56). Tendo isso em vista, optei por utilizar tal situação como um dos módulos da exploração do meu contexto de pesquisa.

Durante esta atividade oral (roda de conversa) com objetivo de conhecer melhor os discentes, conversei com os alunos sobre os assuntos pelos quais tinham mais interesse e que pudessem ser utilizados nas aulas de LP durante o ano letivo de 2020. Eles puderam falar livremente sobre seus interesses, como games, bullying, preconceito dentre outros, e o porquê de tais interesses. Após a realização da atividade, pedi para que elaborassem, em grupos, um pequeno parágrafo justificando suas escolhas. Percebi que tanto na parte oral, quanto na escrita, os alunos demonstraram dificuldades nas produções textuais, não respeitando a vez do outro de se expressar, fazendo-se necessária à minha intervenção a todo momento, e não obedecendo ao comando dado para a produção escrita do parágrafo sobre a escolha do tema. No geral, os alunos escreveram apenas listas com os assuntos mais votados entre eles ou parágrafos sem as justificativas para tais escolhas. Naquele momento, não pensei que uma tarefa, simples a meu ver, pudesse ser tão difícil de ser realizada por eles. Acredito que a forma como a tarefa foi solicitada, com apenas o comando de produzir um parágrafo no qual justificassem seus interesses, contribuiu para o estranhamento e consequente dificuldade que os alunos demonstraram, visto que não delimitei claramente um gênero e não exemplifiquei com uma situação de produção, reafirmando o pensamento de Marcuschi (2008), no qual diz que "um dos problemas constatados nas redações escolares é precisamente este: não se define com precisão a quem o aluno de dirige" (MARCUSCHI, 2008, p.78), não deixando clara e objetiva a "cena textual". Dessa forma, percebi a dificuldade que os alunos encontram para transformar a discussão oral em um texto escrito, mesmo que de forma resumida. Essa atividade de registro escrito não foi inicialmente planejada com foco na intervenção. Meu interesse era apenas de realizar uma sondagem de temas, mas a forma como a atividade se concretizou destacou dificuldades dos alunos quanto à realização, o que me fez refletir sobre alguns aspectos no ensino de LP e, principalmente, sobre como as minhas escolhas e a minha prática dentro de sala de aula podem interferir no processo de aprendizagem dos meus alunos.

Segundo Engel (2000): 
A pesquisa-ação é situacional: procura diagnosticar um problema específico numa situação também específica, com o fim de atingir uma relevância prática dos resultados (ENGEL, 2000, p.184).

Portanto, tendo em vista a importância que essa atividade ganhou para a pesquisa e para a intervenção, optei por incluí-la como um dos módulos da etapa 1, como parte do conhecimento que adquiri da turma e de mim mesma. Além disso, ao analisar o resultado dessa atividade, pude notar problemas na compreensão de conceitos e nos usos de diversos fenômenos gramaticais, como uso dos verbos dicendi e de elocução, emprego dos sinais de pontuação, uso do discurso citado e outros, além de poucos conhecimentos acerca das especificidades dos gêneros textuais.

Logo, nesse módulo, foi delimitado o problema a ser investigado pela pesquisa. Como os alunos demonstraram dificuldade em transpor suas falas em um texto escrito, quebrando a expectativa que coloquei sob a atividade proposta, a chamada de produção inicial foi elaborada tendo em vista o processo de retextualização, pensando não só na transformação do texto entre modalidades, mas também entre gêneros. Através destas observações e pensando em gêneros textuais propícios para o ensino e discussão dos discursos citados e cujo estudo fosse mais relevante para os alunos do oitavo ano, optei, para a elaboração da chamada de produção inicial, pela abordagem dos gêneros do campo jornalístico/midiático entrevista e reportagem, uma vez que exigem comumente a alteração de modalidades para serem veiculados e se encaixam, majoritariamente, nas modalidades oral e escrita, respectivamente, contribuindo para o estudo do processo de retextualização. Assim, pude perceber com mais clareza que o processo de retextualização entre modalidades e/ou entre gêneros era um aspecto problemático para os alunos, mesmo se tratando de um recurso do qual, comumente, fazemos uso na vida diária e não apenas de forma artificial nos exercícios escolares, como afirma Marcuschi (2001). A partir da aplicação da produção inicial, o uso do discurso citado dentro da construção dos gêneros textuais foi observado como um obstáculo para os estudantes. Desta forma, juntamente com o processo de retextualização, o uso do discurso citado nos gêneros textuais escritos está na base da intervenção elaborada e aplicada, uma vez que é um aspecto relevante na construção do gênero reportagem.

Ademais, a presença de alunos de educação especial e inclusiva na turma inquietoume no sentido de que eles são acolhidos pelos alunos, porém não são incentivados a participarem das atividades e da resolução de exercícios, trabalhos e outros de forma individual ou conjunta. Portanto, a inserção desses alunos nas atividades do plano de ação, fazendo com que sua integração e inclusão aconteçam no ambiente da sala de aula (cf. Mantoan, 2015), foi 
abordada ao longo da intervenção, sensibilizando e conscientizando os alunos sobre a importância do reconhecimento e da valorização desses alunos para o espaço escolar. Isso foi feito através da escolha dos textos trabalhados ao longo do projeto, bem como atividades que tinham o objetivo de integrar tais alunos com toda a turma, e, consequentemente, com o espaço escolar.

\subsection{DESCRIÇÃO E ANÁLISE DAS ETAPAS DA INTERVENÇÃO}

Destaca-se que, antes da aplicação das atividades que precederam a produção inicial, foi explicado aos alunos que sou aluna do Mestrado Profissional em Letras (Profletras) pela Universidade Federal de Juiz de Fora (UFJF), e também no que consiste uma pesquisa de mestrado, ressaltando a importância do envolvimento dos alunos para o crescimento não só da pesquisa, mas também do meu, como professora e pesquisadora, e deles próprios, como participantes ativos na construção do conhecimento e reflexão sobre a língua. A intervenção, no formato presencial, teve início no dia dois de março de 2020 e será apresentada em linhas gerais a seguir.

\subsubsection{Primeira etapa: Observando os gêneros textuais entrevista e reportagem}

A chamada de produção inicial foi elaborada tendo em vista o processo de retextualização envolvido nos gêneros entrevista e reportagem e na observação da transposição do discurso na elaboração do novo texto. Para esta etapa da intervenção, algumas aulas com o uso de textos modelares dos gêneros envolvidos foram planejadas, adaptando para a realidade do sistema educacional brasileiro o estilo de sequência didática proposto por Schneuwly e Dolz (2004), com a aplicação do módulo reconhecimento do gênero, conforme Costa-Hübes e Simioni (2014); porém, o aspecto estrutural dos textos não foi trabalhado de forma detalhada, assim como o estudo das características dos gêneros, com o objetivo de se reconhecer, por meio da produção inicial, o que os alunos já traziam de conhecimento dos gêneros e, ainda, de se planejarem ações posteriores com base nesses dados.

A primeira etapa contou com 7 aulas, com cinco aulas precedendo a produção inicial, sendo duas destinadas ao módulo 1 , duas destinadas ao módulo 2 e uma aula com ênfase na realização do módulo 3

Para o primeiro módulo, uma entrevista escrita com o criador do videogame foi projetada para os alunos em seu suporte original. A escolha da entrevista na modalidade escrita 
foi pelo fato de representar recursos mais fáceis em termos de equipamentos a serem usados em sala de aula e de, a princípio, mantermos o foco da intervenção na retextualização entre gêneros textuais e não entre modalidades de uso da língua. Isso teve como intuito verificar, dentre outros aspectos relativos à produção do gênero, como os alunos lidariam com a transposição dos discursos, visto que, durante a pré-intervenção, demonstraram dificuldades ao colocar seu próprio discurso no texto escrito.

Nesse momento, os alunos foram organizados em círculo para facilitar a visão da projeção e para guiá-los no momento de reflexões conjuntas sobre a entrevista lida.

Ainda neste passo, que antecedeu à leitura, os alunos não demonstraram dificuldade em responder as perguntas feitas. Reconheceram o gênero textual projetado como uma entrevista, justificado pela estrutura de perguntas e respostas; citaram jornais, revistas, sites como exemplos de suportes nos quais a entrevista pode ser veiculada; identificaram o site da Revista Galileu como suporte original da entrevista; além de levantarem diversas hipóteses para a escolha de um entrevistado, como por exemplo, por ter realizado algum feito importante.

A seguir, cada aluno recebeu uma cópia do texto para que fosse feita a leitura e as atividades de compreensão textual. Primeiro, fiz a leitura em voz alta para a turma; depois, cada um realizou sua leitura silenciosa e individual. Nesse momento, os alunos continuaram dispostos em círculo, e, após as leituras, as perguntas foram feitas de forma oral. Mais uma vez, as atividades propostas mostraram-se produtivas e, em sua maioria, o desempenho dos alunos foi satisfatório. Eles identificaram o tema da entrevista, exemplificando com elementos do texto; explicaram, de forma coerente, a escolha do entrevistado com relação ao tema; assim como reconheceram que as perguntas feitas ao entrevistado estavam de acordo como o tema da entrevista. Nas duas últimas perguntas ("Qual a forma como o entrevistador foi tratado pelo entrevistado? Por quê?" e "Se você tivesse que fazer alguma pergunta diferente, qual seria?"), os alunos demonstraram mais dificuldade em responder, e a intervenção foi necessária. Logo, em um movimento de pesquisa-ação, esses aspectos serão tratados de forma mais detalhada no módulo sobre o gênero entrevista.

No dia seguinte (módulo 2), algo semelhante foi feito com o gênero reportagem. Nessas duas aulas, a reportagem "Conheça oito benefícios do videogame para o desenvolvimento do seu filho" foi projetada, em formato original, para os alunos, que se sentaram em círculo. Aos alunos, foi dito apenas que o texto se tratava de uma reportagem e, em seguida, alguns pontos foram levantados. Os discentes demonstraram algum conhecimento sobre os suportes onde reportagens são normalmente veiculadas, citando revistas, jornais e sites 
como exemplos. Apesar disso, a maioria deles não se lembrava de ter lido reportagens, com exceção daquelas para tarefas escolares, nem se lembravam de possíveis conteúdos delas.

Após as atividades de pré-leitura, cada aluno recebeu uma cópia do texto para a leitura e compreensão textual. A primeira leitura feita foi de forma coletiva; em seguida, cada um fez sua leitura individual do texto.

Encerradas as leituras, explorei alguns aspectos relacionados ao conteúdo do texto, sem menção às características e à estrutura do gênero textual reportagem. Dessa maneira, não houve foco na estrutura prototípica do gênero reportagem, e sim na compreensão textual, já que era intuito que, na produção inicial, fosse observado o conhecimento que os alunos já tinham acerca do gênero. As perguntas foram discutidas oralmente e, mais uma vez, os alunos mostraram-se participativos. $\mathrm{O}$ assunto do texto foi identificado não só pelo título, mas por outras partes que compõem o texto. Além disso, muitas opiniões sobre o assunto foram levantadas e discutidas pela maioria dos alunos. Já em relação à última pergunta, alguns alunos disseram que ninguém foi entrevistado para a reportagem, enquanto outros apontaram as psicólogas Ana Luiza e Blenda como entrevistadas, justificando apenas que ambos os nomes aparecem ao longo do texto.

No final da aula, solicitei que os alunos levassem jornais e revistas para a aula seguinte. Infelizmente, apenas alguns alunos levaram jornais e revistas para serem compartilhados na atividade, alegando não terem em casa tais materiais. Dessa forma, além daqueles que levei, pedi que a escola pudesse fornecer jornais e revistas antigos para a realização da atividade. Então, na última aula antes da produção inicial, os alunos separaram-se em grupos para a realização da tarefa. Os alunos deveriam procurar reportagens e destacá-las para que fossem compartilhadas com a turma no final da aula. Cada grupo teve 20 minutos para encontrar os textos e depois 5 minutos para mostrar para os colegas e dizer do que se tratavam os textos escolhidos. O tempo disponibilizado para atividade foi suficiente pelo fato de os alunos serem muito sucintos em suas apresentações orais e por ter ficado a cargo de apenas um integrante de cada grupo falar sobre o tema da reportagem escolhida.

Essa atividade serviu de análise prévia quanto ao reconhecimento do gênero, pois percebi a dificuldade que todos os grupos tiveram para identificar textos do gênero reportagem, visto que, no geral, os grupos apresentaram notícias, exceto um grupo que apresentou dois textos, sendo uma notícia e uma reportagem.

Logo após a realização das atividades descritas anteriormente, os alunos receberam a chamada de produção inicial. Nela, constavam algumas informações, como o gênero textual a ser escrito, o público-alvo, o suporte onde o texto estaria e a finalidade da produção. Além 
disso, foi dito que os alunos deveriam transformar a entrevista abordada na atividade do módulo 1 em uma reportagem. Acerca do texto a ser produzido, as únicas informações proferidas além das já descritas foram referentes à paragrafação e ao respeito às margens da folha.

Durante a produção dos textos, fui indagada muitas vezes sobre a realização da tarefa. Os alunos reclamaram que não sabiam escrever uma reportagem, além de perguntar como ela era escrita, se precisava de título, se teriam que assinar no corpo do texto, entre muitas outras indagações. Nesse momento, destaquei para os alunos que se tratava de uma pesquisa de mestrado, expliquei o significado da palavra diagnóstico e tranquilizei-os, dizendo que, para iniciar, o mais importante era que eles produzissem o texto da forma como eles acreditavam que seria uma reportagem. Desse modo, embora tenhamos apresentado aos alunos um texto modelar do gênero reportagem, a fim de instigar uma primeira reflexão sobre ele, como sugere a SD proposta por Costa-Hübes e Simioni (2014), foi uma opção, para a análise da produção inicial que eu não interferisse de modo a destacar ou elencar as características prototípicas do gênero reportagem nesse momento de produção inicial, a fim de observar o conhecimento que os alunos já traziam de anos anteriores ou de situações anteriores acerca do gênero. Tal observação elucidou a constituição de etapas e módulos e pôde se aprofundar em questões que se mostraram sensíveis quando da produção inicial.

Ao todo, 33 produções foram entregues para a análise.

\subsubsection{Descrição e análise dos textos produzidos na primeira etapa}

Após a atividade realizada sobre os assuntos em que os alunos têm mais interesse, e a percepção da dificuldade que apresentaram para retextualizar a conversa da roda de conversa (modalidade oral) para uma justificativa escrita (modalidade escrita), foram planejadas e aplicadas atividades que objetivavam observar o conhecimento dos alunos sobre os gêneros textuais entrevista e reportagem, visando à produção inicial que se incidia sobre a retextualização de um gênero tipicamente da modalidade oral, apresentado a eles na modalidade escrita (entrevista) para um gênero da modalidade escrita (reportagem). Através da aplicação da produção inicial, diagnosticamos as necessidades dos alunos em relação não só ao processo de retextualização, mas também à estrutura e às características prototípicas do gênero reportagem, bem como ao uso do discurso citado na construção de tal gênero.

Tais atividades precederam a produção inicial, que serviu como diagnóstico para a elaboração das demais etapas do plano de intervenção, sendo a análise dos textos produzidos pelos estudantes essencial instrumento de levantamento e análise de dados para esta pesquisa. 
Na produção inicial, os alunos foram convidados a retextualizar um texto. O objetivo, como já mencionado, era transpor uma entrevista para uma reportagem. Para a análise de dados das produções, foi elaborada uma tabela que continha características pertinentes à construção do gênero reportagem e sua estrutura, além de aspectos gramaticais cujos usos interferem diretamente na produção de tal gênero. Para tanto, foram observados os seguintes aspectos: manchete, subtítulo, lide, pessoa do discurso, coesão, verbos dicendi, discurso direto, discurso indireto, pontuação. Todos eles foram julgados sob os seguintes critérios: alcançaram, alcançaram parcialmente e não alcançaram, como se pode notar pela tabela de análise a seguir:

Tabela 1 - Aspectos analisados na produção inicial

\begin{tabular}{|l|l|l|l|}
\hline Aspectos observados & Alcançaram & Alcançaram parcialmente & Não alcançaram \\
\hline Manchete & & & \\
\hline Subtítulo & & \\
\hline Lide & & \\
\hline Pessoa do discurso & & \\
\hline Coesão & & \\
\hline Uso de verbos dicendi & & \\
\hline Uso do discurso direto & & \\
\hline Uso do discurso indireto & & \\
\hline Pontuação & & \\
\hline
\end{tabular}

Fonte: Autoria própria (2020).

Com relação à manchete, foram considerados como "alcançaram" os textos que apresentaram um título criativo e que despertasse a atenção do leitor. Como "alcançaram parcialmente", os textos que apresentaram algum título, mesmo que não satisfatório, e como "não alcançaram", os textos que não apresentaram título algum. A manchete foi um aspecto observado nos textos, por se tratar de uma característica prototípica do gênero reportagem, assim como o subtítulo ou linha fina, o lide e a pessoa do discurso utilizada na produção do texto.

No que se refere ao uso do subtítulo ou linha fina, foram considerados como "alcançaram" os textos que apresentaram uma espécie de subtítulo em linha fina que continha informações complementares ao título principal ou a presença de intertítulos; como "alcançaram parcialmente", os textos que apresentaram algum subtítulo em linha fina, mesmo que sem informações complementares ao título principal, e como "não alcançaram", os textos que não apresentaram nenhum subtítulo. Vale ressaltar que o uso do subtítulo na reportagem é facultativo, mas optou-se por observar seu uso pela sua importância em gêneros jornalísticos, como a reportagem. 
Com relação ao lide, foram considerados como "alcançaram" os textos que apresentaram um panorama mais detalhado aos leitores sobre o conteúdo do texto; como "alcançaram parcialmente", os textos que apresentaram alguma informação sobre o panorama da reportagem e como "não alcançaram", os textos que não apresentaram nenhuma informação esperada em um lide (O quê? Quem? Quando? Como? Onde? Por quê?). É importante destacar que, por se tratar de um texto mais detalhado, a reportagem não precisa responder a todas as perguntas do lide. Porém, como critério de pesquisa, optou-se por observar nos textos a quantidade de informações presentes no primeiro parágrafo, como formas de atrair a atenção do leitor.

Ao estabelecer a coesão como aspecto a ser analisado nesses textos, esperava-se que houvesse um texto sem repetições desnecessárias, em que se utilizavam recursos comuns em reportagens escritas, como a reiteração por sinônimos, a substituição por pronomes e outros. No caso do atendimento ao uso desses recursos, a produção seria considerada como adequada. Assim, foram considerados como "alcançaram" os textos que utilizaram diferentes formas de substituição lexical; como "alcançaram parcialmente", os textos que se valeram de alguma substituição, mas a repetiram ao longo do texto, e como "não alcançaram", os textos que não fizeram uso de nenhuma estratégia de substituição lexical.

A forma como os alunos se reportavam à voz do outro chamou atenção já na primeira leitura das produções iniciais. Em relação ao uso dos verbos dicendi, levando em consideração a coesão lexical, esperava-se que os alunos os utilizassem de forma variada (com recursos lexicais como afirmar, perguntar, indagar, responder, dizer, falar, confirmar, declarar, concordar etc), no uso dos tipos de discurso ao longo do texto, levando em consideração a voz do entrevistador e do entrevistado. Como "alcançaram", foram considerados os textos que utilizaram diferentes verbos dicendi na transposição dos discursos presentes na entrevista para a reportagem; como "alcançaram parcialmente", os textos que fizeram uso de algum verbo dicendi, mesmo que o repetindo ao longo do texto, e como "não alcançaram", os textos que não fizeram uso de verbos dicendi ou quando copiavam trechos transcritos do texto-base (entrevista). Como será visto adiante, tal expectativa não foi atendida, visto que, quando utilizavam, os alunos não variavam o uso de tais verbos.

Com relação ao uso dos tipos de discurso, a retextualização demandada na atividade de produção revelava a importância do uso dos diferentes discursos pelos alunos, de forma adequada aos gêneros textuais envolvidos. Assim, fez-se relevante observar como utilizariam as características do discurso direto ou indireto para inserir as perguntas e as repostas da entrevista para a reportagem. Para o uso do discurso direto, foram considerados como 
"alcançaram" os textos que utilizaram verbos dicendi para introduzir a fala das vozes presentes na entrevista, assim como o uso correto da pontuação; como "alcançaram parcialmente", os textos que usaram as características citadas anteriormente, com algum desvio de uso conforme o padrão, e como "não alcançaram", os textos que não utilizaram o discurso direto ou mantiveram a estrutura de entrevista ao longo da produção. Para o uso do discurso indireto, esperava-se que os alunos utilizassem a terceira pessoa (narrador falando pelos entrevistados), além dos verbos de elocução. Nesse caso, foram considerados "alcançaram" os textos que fizeram uso de ambos; como "alcançaram parcialmente", os textos que fizeram tais usos com algum desvio e como "não alcançaram", os textos que não utilizaram o discurso indireto ou reproduziram a entrevista sem modificar o formato. Não tínhamos certeza sobre o fato de o uso do discurso citado já ter sido estudado pelos alunos em anos anteriores, porém havia expectativas, tendo em vista seus percursos escolares, que já o tenham observado de maneira mais formalizada em aulas de LP em textos narrativos ficcionais ou em textos do campo jornalístico/midiático, visto ser esse conteúdo apontado pela BNCC para anos anteriores.

Em relação à pontuação, embora se tenha observado todo o texto, optou-se por se focar nesta análise em uma das questões que mais chamou atenção: os trechos que envolviam a transposição dos discursos. Esperava-se que os alunos utilizassem o sistema de pontuação de forma correta, principalmente, no uso do discurso direto. Foram considerados como "alcançaram" os textos que utilizaram os sinais de pontuação nas construções do discurso direto e do discurso indireto sem qualquer desvio; como "alcançaram parcialmente", os textos com algum desvio em relação ao uso dos sinais de pontuação e como "não alcançaram", os textos em que a pontuação ocorreu de forma inadequada.

Sabe-se que muitos são os fenômenos linguísticos que podem ser analisados na produção de um texto, porém muitos deles, como ortografia, concordância, regência entre outros, estarão presentes na produção dos mais diversos gêneros, tanto que muitos foram encontrados nas produções dos alunos participantes da pesquisa. No intuito de focar a análise na produção de uma reportagem, foram escolhidos e analisados aspectos gramaticais relevantes para a construção desse gênero, principalmente, levando em consideração a retextualização da entrevista para a reportagem e a hipótese de que haveria dificuldade na produção da reportagem e nos usos dos tipos de discurso, tendo em vista experiências de aulas anteriores.

O primeiro fator que saltou aos olhos na análise relaciona-se à disposição dos textos na folha dada para a produção. Conforme pode-se perceber nos anexos F e G, a chamada de produção dada possuía um espaço com margens para que a produção fosse feita, não limitando a extensão do texto, visto que o aluno poderia utilizar quantas folhas fossem necessárias. Porém, 
muitos alunos demonstraram dificuldade em relação à paragrafação e, principalmente, à escrita de um texto justificado. Vale lembrar que os alunos foram advertidos quanto a esses aspectos antes de seu processo de produção. Mesmo assim, apenas 11 alunos usaram parágrafos em seu texto e um número ainda menor teve o cuidado de alinhar o texto às margens.

Como já mencionado, a tabela utilizada para a análise dos dados foi elaborada pensando nos aspectos fundamentais para a construção de uma reportagem, usando uma entrevista para o processo de retextualização, além de outros textos base para a construção de um novo texto, conforme aponta Matêncio (2002). Dessa forma, além dos aspectos estruturais do gênero produzido, os aspectos gramaticais eleitos, de acordo com a hipótese levantada, foram relacionados ao uso dos tipos de discurso, assim como o emprego dos verbos dicendi e pontuação. Além desses aspectos, com o início da análise de dados, viu-se a importância de observar a coesão através do uso de elementos de substituição, como sinônimos e pronomes, como forma de evitar a repetição ao longo do texto.

Tal qual será possível notar, observando a tabela, a maioria dos alunos, embora reconheçam alguns aspectos estruturais do gênero reportagem, não conhecem muitas das estruturas essenciais que colaboram para a construção desse gênero. De acordo com a perspectiva de Schneuwly e Dolz (2004), o gênero reportagem está agrupado no tipo relatar, o que pode justificar a aproximação dos textos produzidos com o gênero biografia, que faz parte do mesmo tipo. Além disso, alguns textos não utilizam as informações presentes na parte da entrevista, limitando-se a usar apenas informações presentes no trecho do texto que antecede às perguntas respondidas pelo inventor do videogame para compor o seu texto, eliminando informações importantes e que poderiam contribuir muito para o conteúdo abordado. Isso parece se dever ao fato de que essa parte da entrevista se assemelha à estrutura composicional de uma reportagem.

Foram analisadas 33 produções textuais de alunos do $8^{\circ}$ ano do Ensino Fundamental II. Vale ressaltar que 7 alunos mantiveram o formato do gênero entrevista, copiando tudo da mesma forma que aparece no texto-base, não alcançando o uso do discurso direto, já que são copiadas as falas do entrevistador e entrevistado, porém sem o uso dos verbos dicendi ou da pontuação correta, seja pelo uso das aspas na citação, seja pelos dois pontos e travessão. Além disso, muitos alunos copiaram trechos do texto-base para a produção, ou seja, restringiram-se a transcrever partes da entrevista para sua produção, incluindo o texto que antecede às perguntas. Nesse sentido, observou-se a dificuldade dos alunos nos aspectos observados na análise, confirmando as hipóteses levantadas antes da aplicação da produção inicial. 
A seguir, apresentamos a tabela elaborada para a análise da estrutura do gênero textual reportagem e dos fenômenos linguísticos observados no uso do discurso citado em sua produção com os dados quantitativos/percentuais levantados a partir da correção dos textos produzidos pelos alunos na atividade de produção inicial:

Tabela 2 - Análise quantitativa/percentual das produções

\begin{tabular}{|l|c|c|c|}
\hline Aspectos observados & Alcançaram & Alcançaram parcialmente & Não alcançaram \\
\hline Manchete & $0(0 \%)$ & $11(33,33 \%)$ & $22(66,66 \%)$ \\
\hline Subtítulo & $0(0 \%)$ & $0(0 \%)$ & $33(100 \%)$ \\
\hline Lide & $4(12,12 \%)$ & $15(45,45 \%)$ & $14(42,42 \%)$ \\
\hline Pessoa do discurso & $12(36,36 \%)$ & $21(63,63 \%)$ & $0(0 \%)$ \\
\hline Coesão & $0(0 \%)$ & $20(60,6 \%)$ & $13(39,39 \%)$ \\
\hline Uso de verbos dicendi & $0(0 \%)$ & $15(45,45 \%)$ & $18(54,54 \%)$ \\
\hline Uso do discurso direto & $0(0 \%)$ & $3(9,09 \%)$ & $30(90,9 \%)$ \\
\hline Uso do discurso indireto & $0(0 \%)$ & $13(39,39 \%)$ & $20(60,6 \%)$ \\
\hline Pontuação & $3(9,09 \%)$ & $20(60,6 \%)$ & $10(30,3 \%)$ \\
\hline
\end{tabular}

Fonte: Autoria própria (2020).

A seguir, separadamente, cada aspecto presente na tabela será analisado. Por meio dela, pode-se notar que tipo de conhecimento os alunos já trazem quanto ao gênero reportagem e aos aspectos do gênero analisados.

Uma característica marcante na reportagem é a presença da manchete, ou seja, do título. Embora essa seja uma característica presente em diversos gêneros textuais, 22 alunos sequer inseriram um título em seu texto. Aqueles que o colocaram, 11 alunos alcançaram apenas de forma parcial, visto que não foram manchetes que causassem impacto e chamassem a atenção do leitor. Como exemplo, pode-se citar títulos como "O primeiro videogame”, "O vídeo game criado por Ralph baer", "O início do vídeo game”, entre outros bem semelhantes. Dessa forma, apesar de a manchete aparecer em 11 textos, em nenhum deles foi usada criatividade que despertasse a atenção do leitor. Tal dado aponta para a necessidade de um trabalho incisivo quanto à importância das manchetes nos textos jornalísticos na etapa 4.

Em seguida, o aspecto analisado é o subtítulo, ou seja, um título secundário presente nas reportagens e em outros textos jornalísticos como a notícia. Nenhum aluno se utilizou desse recurso. Logo, pode-se afirmar que eles não têm o conhecimento de que tal estrutura faz parte da reportagem. Nenhum aluno colocou subtítulo ou intertítulos, nem algum enunciado que seja semelhante a eles. Dessa maneira, os alunos demonstraram não reconhecimento dessa estratégia como um recurso organizador da escrita e da leitura desse gênero. 
Já no corpo do texto, a reportagem apresenta o lide, que são as principais informações do conteúdo abordado (o quê?, quem?, onde?, quando?, como?, por quê?), resumidas no primeiro parágrafo. Dos textos analisados, 4 apenas apresentaram lide completo e 15 apresentaram de forma parcial. Os catorze textos restantes não abordaram tais informações no primeiro parágrafo. Vale ressaltar que, quanto mais completo o lide, mais informações relevantes sobre o conteúdo são apresentadas ao leitor. Dessa forma, mesmo que, em alguns casos, a sua ausência não prejudique a construção do texto, optou-se por analisar se foram usadas todas as suas etapas por se tratar de um aspecto importante para a compreensão no que se refere à retextualização.

Com o intuito de ilustrar esses resultados numéricos, alguns exemplos serão apresentados. A aluna $17^{3}$ iniciou seu texto da seguinte forma:

Quadro 4: Trecho de produção inicial - exemplo 1 (aluno 17)

"Hoje vamos falar sobre o famoso VIDEOGAME e quem o criou. Em 1972 foi lançado no mercado o primeiro videogame que recebeu o nome de Magnavox Odyssey ou simplesmente Odyssey 100 pela empresa Magnavox, braço direito da Philips."

Fonte: A autora (2020).

Nesse trecho, a aluna apresenta algumas das informações que resumem o conteúdo que será abordado ao longo do texto, como o que (videogame) e quando (1972). Já a aluna 19 escreve:

Quadro 5: Trecho de produção inicial - exemplo 2 (aluno 19)

"O primeiro vídeo game da história mais conhecido como Odyssey 100 foi criado pelo engenheiro alemão Ralfh Baer em 1966, mesmo a ideia aparecendo em 1951 ela so foi posta em pratica 15 anos depois."

Fonte: A autora (2020).

Tal trecho também apresenta algumas informações que constituem o lide, como o assunto (videogame), a pessoa (Ralph Baer) e o momento (1966).

\footnotetext{
${ }^{3}$ Todos os trechos retirados de produções textuais dos participantes e citações de suas participações durante as atividades orais foram reproduzidos conforme os originais, sem nenhuma alteração.
} 
Outros alunos iniciam o texto apresentando alguma informação presente na entrevista, mas não nos moldes de um lide. Por exemplo, pode-se citar o aluno 32 ou o 26, que escreveram:

Quadro 6: Trecho de produção inicial - exemplo 3 (aluno 32)

"O engenheiro Alemão Ralph Baer e um sujeito modesto. E o criador do primeiro videogame da historia, Odyssey 100."

Fonte: A autora (2020).

Quadro 7: Trecho de produção inicial - exemplo 4 (aluno 26)

“O emprego de Ralph Baer: Ralph Baer lançou o seu primeiro videogame em 1974, ele sempre pensou que um aparelho de tv poderia fazer muito mais do que exibir programas e comerciais, a ideia em 1951 mas o projeto so avançou em 1966."

Fonte: A autora (2020).

Após o lide, analisamos a pessoa do discurso usada na produção dos textos. Esse aspecto foi alcançado, mesmo que parcialmente, por todos os alunos. Logo, subentende-se que eles demonstram conhecimentos sobre os tipos de pessoas prototipicamente usadas no gênero reportagem. Os trinta e três alunos, mesmo que de forma parcial, usaram a $3^{a}$ pessoa. Como exemplo, podem ser citados trechos do aluno 17 ou do aluno 28, os quais optaram por um texto que se aproxima mais da tipologia relatar, contando fatos da vida pessoal e profissional do entrevistado:

Quadro 8: Trecho de produção inicial - exemplo 5 (aluno 17)

"O criador é um engenheiro alemão chamado Ralph Baer, que hoje aos 87 anos ainda desfruta de sua criação."

Fonte: A autora (2020). 
Quadro 9: Trecho de produção inicial - exemplo 6 (aluno 28)

"O primeiro videogame foi criado por Ralph Baer. No começo de sua projeto as pessoas não botavam muita confiança, pois achavam que seria algo não muito funcional, algo que Baer achava o contrário, pois acreditava em quão o aparelho televisor era capaz de apenas mostra coisas da mídia. Então o primeiro videogame foi criado o Odyssey 100, que com a ajuda da empresa Magnavox lançou seu primeiro modelo no mercado em 1972."

Fonte: A autora (2020).

O aspecto coesivo analisado limitou-se ao uso de palavras que pudessem substituir outras, evitando a repetição vocabular ao longo do texto. Portanto, foi observado o uso de sinônimos, pronomes e outros no processo de substituição. Nenhum aluno alcançou tal aspecto de forma satisfatória; 20 alcançaram de forma parcial, utilizando pronomes pessoais ou de tratamento no lugar do nome do criador, e expressões retiradas da entrevista para substituir a palavra videogame, como os alunos 16 e 7 , respectivamente, nos trechos:

Quadro 10: Trecho de produção inicial - exemplo 7 (aluno 16)

"Ele revela que está envolvido em um novo game, só que infelismente não pode nos dizer muito sobre esse assunto."

Fonte: A autora (2020).

Quadro 11: Trecho de produção inicial - exemplo 8 (aluno 17)

"Até os mais próximos torceram o nariz para a engenhoca."

Fonte: A autora (2020).

Os alunos que não alcançaram, 13 no total, limitaram-se a usar o nome do entrevistado ao longo de todo o texto, como a aluna 6, que repete o nome Baer 8 vezes em sua produção, utilizando-o no começo de todos os parágrafos do texto.

A seguir, analisou-se o uso dos verbos dicendi utilizados, principalmente, na parte em que os alunos se ocuparam de transpor a entrevista para a reportagem. Mais uma vez, nenhum aluno alcançou o aspecto analisado de forma satisfatória, pois os estudantes limitaram-se ao uso dos verbos "perguntar", "responder" e "dizer", como o aluno 10. 
Quadro 12: Trecho de produção inicial - exemplo 9 (aluno 10)

“...o perguntaram se ele ainda joga videogame e qual o jogo favorito ele respondeu..."

Fonte: A autora (2020).

Há ainda alunos que não utilizaram nenhum verbo dicendi ao longo do texto, como o 4, com a produção de apenas 10 linhas.

O uso dos discursos direto ou indireto está diretamente relacionado ao uso dos verbos dicendi, já que, para a construção de ambos, há a necessidade, no gênero reportagem, de que tais verbos sejam utilizados para a indicação das vozes ou ações que aparecem no texto. Pela análise das produções, percebeu-se que os alunos têm uma tendência maior em utilizar o discurso indireto:13 alcances parciais, enquanto o uso do discurso direto limitou-se a 3 alcances parciais. Isso pode se dever ao fato de ter sido solicitado a eles que justamente retextualizassem a entrevista (gênero em que se evidencia o discurso direto), transpondo-a para a reportagem, que pode ter sido tomada pelos estudantes como tendo aspecto diferencial a presença constante do discurso indireto. De qualquer forma, esse dado revelou ser importante desenvolver um trabalho que vise a demonstrar a relevância dos discursos no gênero reportagem, abordando assuntos que versem sobre a fidedignidade ou não do discurso apresentado nele.

Quadro 13: Trecho de produção inicial - exemplo 10 (aluno 28)

"Bear afirma que sempre esta envolvido com a indústria de jogos e tem alguns que mais gosta como: pacman, pingue-pongue etc. Ele normalmente não joga muito, mas joga quando seus netos estão em sua casa nas horas vagas."

Fonte: A autora (2020).

O aluno 28 faz uso do discurso indireto ao se referir a Baer. O aluno afirma algo que foi retirado das perguntas da entrevista. Algo semelhante ocorre com o texto do aluno 31:

Quadro 14: Trecho de produção inicial - exemplo 11 (aluno 31)

"Disse ele que o jogo é bastante interessante e disse ele que já jogou muito pac-man e spaceinvaders também."

Fonte: A autora (2020).

Em tais exemplos, observa-se o uso do discurso indireto ao se inserir na $3^{\text {a }}$ pessoa do discurso as falas do entrevistado, com emprego dos verbos de elocução nessa construção. Nota- 
se repetição na escolha linguística do verbo "dizer" neste e em outros trechos do texto desse aluno.

Já o uso do discurso direto, além de reduzido, revela dificuldades dos alunos em sua estruturação, não havendo a introdução da fala pelo narrador. Os alunos, que alcançaram parcialmente, apenas transcrevem as perguntas e respostas para dentro do texto, como o aluno 32, que inicia um parágrafo da seguinte forma:

Quadro 15: Trecho de produção inicial - exemplo 12 (aluno 32)

"O senhor ainda joga videogame? Qual seu favorito? Sempre foi e sempre será o ping-pong, da para acreditar, apesar do fato de ser feito com gráficos primitivo, e um jogo bem interessante." Fonte: A autora (2020).

Ou, ainda, alunos como 33 que misturam os tipos de discurso no mesmo trecho:

Quadro 16: Trecho de produção inicial - exemplo 13 (aluno 33)

“- O senhor ainda joga videogame? / - ele diz que continua jogando pingue-pongue e diz que um jogo bastante interessante e um dos jogos atuais dele é chamado de 'wii'."

Fonte: A autora (2020).

A partir da análise desses aspectos, os resultados são compatíveis com a hipótese levantada de que os alunos têm pouco conhecimento acerca do uso dos tipos de discurso e dos papéis que assumem em produções textuais escritas formais.

A pontuação também foi um dos aspectos observados por ter papel fundamental, principalmente, para o uso do discurso direto. Todos os alunos demonstraram dificuldades em utilizar os sinais de pontuação, não só ao tentar inserir os discursos, mas ao longo do texto como um todo. Isso ocorre com a produção da aluna 1, cujo texto completo se apresenta, praticamente, em um único bloco:

Quadro 17: Trecho de produção inicial - exemplo 14 (aluno 1)

"O engenheiro Ralph Baer criador do primeiro videogame. Ralph Baer é um cara muito sortudo ele fala que não foi nada fácil vender sua ideia outros viam pelo lado positivo e outros negativo ele criou o primeiro jogo odyssey 100 foi produzido e vendido ate 1974."

Fonte: A autora (2020). 
Com a análise dos textos e o levantamento dos dados, os resultados sugerem que os alunos apresentam dificuldades para a produção de uma reportagem, principalmente no que se refere às características prototípicas desse gênero, além de não apresentarem domínio adequado quanto ao uso dos distintos tipos de discurso.

Além disso, dados importantes na análise das reportagens produzidas, como a falta de compreensão na recepção do comando da chamada de produção textual e a produção de textos incoerentes e com informações que não estão de acordo com aquelas presentes na entrevista utilizada no processo de retextualização também apontam para a necessidade de se trabalhar aspectos específicos na intervenção. Dessa forma, através da abordagem da perspectiva da análise linguística, inserindo o gênero no centro do trabalho da sala de aula e a percepção de que aspectos gramaticais podem ser a ele atrelados, espera-se alcançar também uma melhora na competência leitora dos estudantes, instigando de maneira significativa não só a produção textual, mas também a compreensão.

Além dos aspectos da tabela, outros pontos chamaram a atenção na análise das produções textuais feitas pelos alunos, como o uso de letras maiúsculas no meio de frases e a incoerência de alguns textos por não apresentarem uma sequência textual lógica. Estas questões também serão abordadas ao longo da intervenção, pois são fundamentais para melhorar a capacidade de produção escrita dos alunos.

De forma a permitir uma melhor visualização dos dados, apresentaremos a seguir um gráfico com os dados, referentes à tabela com a análise quantitativa da produção inicial. Por meio das barras do gráfico, fica clara a discrepância entre o número de alunos que alcançaram a expectativa de algum dos aspectos analisados em relação ao número de alunos que alcançaram parcialmente ou não alcançaram a expectativa de tais aspectos. 
Gráfico 1 - Análise quantitativa percentual da produção inicial

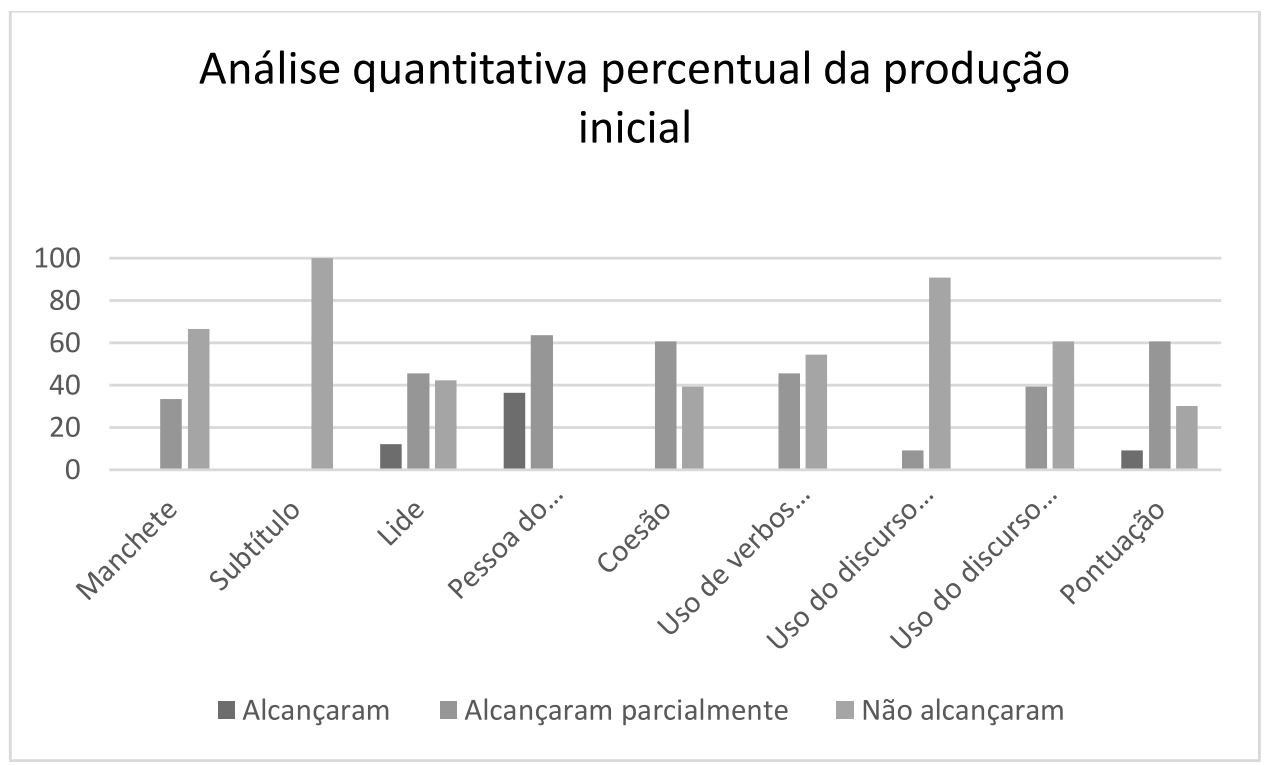

Fonte: Autoria Própria (2021).

Observa-se, através do gráfico 1, que apenas três aspectos analisados (lide, pessoa do discurso e pontuação) foram alcançados por parte dos alunos que fizeram a produção inicial, mesmo assim, nenhum deles ultrapassa a marca dos 50\% dos alunos participantes. Outro fato que nos chama a atenção é a ausência do subtítulo ou linha fina em todos os textos produzidos, o que nos leva a indagar se os alunos desconhecem tal estrutura, tão frequente na construção dos textos do campo jornalístico/midiático ou se estão tão habituados com modelo tradicional e cristalizado de produção textual escolar que apenas focam na escolha de um título para o texto, qualquer que seja. Além disso, percebe-se que, apesar de presente em todos os aspectos, o número de alunos que alcançou parcialmente a expectativa ainda é inferior ao número de alunos que não alcançou a expectativa em quase todos os aspectos analisados.

Tal análise nos motivou à criação das etapas presentes na intervenção, numa tentativa de priorizar os aspectos citados, dentro do que nos foi possível com o ensino remoto e com participantes voluntários. A seguir, serão descritas e analisadas atividades presentes em alguns dos módulos das etapas que aconteceram entre a produção inicial e a produção final, retratando as dificuldades demonstradas pelos participantes, seus ganhos durante o processo, além das minhas impressões enquanto professora, pesquisadora e participante da pesquisa. 


\subsubsection{Segunda etapa: Ambientação e primeiras reflexões sobre a temática da Inclusão Escolar}

Nesta etapa, o objetivo era envolver os alunos na temática social que perpassaria todo o projeto. Como já mencionado, a inclusão de alunos com deficiência sempre me inquietou por não ver uma inclusão além do social, ou seja, para a maioria dos alunos com deficiência, a escola não passava de um ambiente de socialização e não de desenvolvimento, de aprendizado e de construção de um cidadão crítico. Por muitas vezes, os alunos com deficiência são esquecidos dentro de sala de aula no que se refere ao seu processo de ensino-aprendizagem. Como professores, não sabemos e não somos preparados para lidar com esse aluno de forma a contribuir com seu desenvolvimento escolar.

Infelizmente, a ideia inicial de abordagem dessa temática não pôde ser desenvolvida por conta da suspensão das aulas presenciais motivada pela pandemia da Covid-19. O intuito da intervenção era envolver mais os alunos com deficiência nas atividades desenvolvidas em sala de aula com a ajuda dos alunos sem deficiência, mostrando que a inclusão não deve ser apenas social e que todos em sala de aula têm um papel fundamental no desenvolvimento acadêmico desses alunos, pois, a afetividade entre crianças, professores e família, ou seja, entre os membros da comunidade escolar, é ponto crucial para o desenvolvimento da aprendizagem dos alunos com deficiência, conforme Santos e Moura (2018).

Com a aplicação da intervenção de forma remota, dentre os poucos alunos que aceitaram o convite para participar, não tivemos nenhum aluno com deficiência na pesquisa. Ao longo do ano letivo de 2020, a escola conseguiu estabelecer contato com apenas um dos três alunos com deficiência dessa turma, e este não tinha acesso à internet com facilidade. Dessa forma, não havia a possibilidade de participação na intervenção. Sendo assim, optamos por remodelar o objetivo inicial, enfocando a valorização desses alunos no ambiente escolar.

A etapa 2, intitulada Ambientação e primeiras reflexões sobre Inclusão Escolar, foi constituída por 4 módulos (Módulo 1: Ambientação; Módulo 2: Reflexão e Sensibilização; Módulo 3: Coleta de informações; Módulo 4: Da temática ao gênero entrevista), totalizando 15 aulas. Nessa etapa, como o objetivo era a reflexão sobre a temática, utilizamos gêneros textuais diferentes daqueles que foram destaques ao longo da intervenção, como uma animação e uma tirinha, e, no último módulo, passamos ao gênero entrevista, constituindo uma ponte com a próxima etapa. Além disso, aplicamos um questionário, que será analisado juntamente com as outras atividades ao longo desta seção. 
No módulo 1, a fim de despertar a reflexão quanto à inclusão dos alunos deficientes, sensibilizar os alunos quanto à temática da intervenção e aproveitar o novo espaço escolar permitido pelo uso da internet para se fazer a exploração de gêneros multimodais, foi selecionada uma animação intitulada Conscientização IGA29 - Inclusão, disponível no canal do YouTube. A atividade inicial contou com a apresentação de uma animação cuja história foi emocionante, não só para mim, mas também para alguns dos alunos participantes que demonstraram sua emoção. Essa atividade foi importante porque provocou os alunos a pensar sobre a exclusão de pessoas com deficiência. No caso do vídeo, uma criança cadeirante era excluída pelas outras em um parque e, por conta disso, desaparecia, sempre insistindo em voltar para o mesmo lugar, apesar da forma como era tratado. Depois de presenciar toda sua vontade e luta para estar ali, junto às outras crianças, ele é acolhido por todos, e a inclusão acontece.

Em conversa com os alunos a respeito da videoanimação veiculada, as percepções foram variadas: os alunos indicaram a rejeição sofrida pelo personagem como exclusão, preconceito e bullying. Os alunos mostraram-se sensíveis às cenas retratadas. Nas palavras do aluno 4 "não faz nenhum sentido ninguém querer brincar porque ele é cadeirante".

Outro ponto fundamental da atividade foi a análise dos elementos não linguísticos do texto e a forma como eles contribuem para a sua compreensão, uma vez que não havia falas dos personagens ou legendas ao longo da animação. Conforme aponta Dionísio (2011), na "sociedade contemporânea, a prática de letramento da escrita, do signo verbal deve ser incorporado à prática de letramento da imagem, do signo não verbal” (DIONÍSIO, 2011, p.139). Desde o primeiro momento em que começamos a repensar a intervenção em um novo formato, de aulas remotas, vimos a importância e a necessidade do trabalho com a multimodalidade, principalmente, por ser uma intervenção virtual. Minha mediação foi necessária, uma vez que os alunos demonstraram não ter muita experiência na exploração dos elementos multimodais como essenciais para a construção e compreensão do texto, especialmente no que tange aos elementos não linguísticos. Os alunos apontaram as ações e as expressões faciais como elementos que contribuíam para entender a mensagem do vídeo, mas não se atentaram para elementos como a música e o cenário, por exemplo.

O módulo 2 (Reflexão e Sensibilização) também teve o objetivo de sensibilizar os alunos em relação à inclusão de pessoas com deficiência em diferentes espaços. Nesse módulo, a análise da HQ intitulada Tom em: caça aos ovos..., presente no site Casa Adaptada, levou os alunos a refletir sobre os diversos problemas de acessibilidade que as pessoas com deficiência encontram nos espaços que frequentam, como a ausência de rampas para a locomoção de cadeirantes. Ao final deste módulo, os alunos perceberam que a falta de lugares adaptados 
também é uma forma de exclusão e coloca as pessoas com deficiência no papel de dependentes, pois "sempre precisam da boa-vontade de alguém para ajudá-las" (segundo palavras do Aluno 1).

O módulo 3 (Colhendo informações) foi elaborado com o objetivo de analisar a realidade dos participantes em relação à inclusão de pessoas com deficiência, para considerar alguns aspectos como: se tal tema é algo que faz parte da vida deles além do espaço escolar, se eles observam a presença de pessoas com deficiência nos lugares que frequentam. Assim, objetivava-se constatar suas percepções, pensamentos e opiniões sobre a temática. A aplicação de um questionário foi muito interessante e mostrou-se reveladora em muitos aspectos. A princípio, ficamos na dúvida sobre o melhor momento para aplicá-lo, pois não queríamos que a percepção dos alunos sobre o tema fosse moldada de alguma forma pelas reflexões que poderiam ser suscitadas ao longo da etapa 2. Decidimos aplicá-lo após algumas atividades, mas não no final da etapa. Dessa maneira, eles já estavam inseridos na temática e poderiam responder as questões com um pouco mais de clareza sobre o assunto. Vale ressaltar que, no momento da aplicação, os alunos eram lembrados da importância de serem honestos em suas respostas, pois nosso intuito era refletir e crescer juntos, e não nos julgarmos em relação às discussões feitas durante as aulas.

O questionário, aplicado de forma remota via Google Formulário, foi formulado com 9 perguntas, sendo 4 de múltipla escolha e 5 discursivas. Os alunos responderam sobre sua convivência dentro e fora da escola com pessoas com deficiência, sobre o tratamento que dão a essas pessoas, sobre o andamento das aulas em turmas com alunos com deficiência e deram sua opinião sobre a importância ou não da inclusão desses alunos no ambiente escolar. Vale ressaltar que os alunos participantes da pesquisa estavam matriculados em uma turma com 3 alunos com necessidades especiais. A seguir, apresentamos um quadro com as questões presentes no questionário respondido pelos alunos no módulo 3 da etapa 2 .

Quadro 18: Questionário - Inclusão de pessoas com deficiência: vivências, pensamentos e opiniões

\begin{tabular}{|l|l|}
\hline Questão 1 & Na escola onde você estuda, há alunos de Educação Especial e Inclusiva? \\
\hline Questão 2 & Há ou já houve, em sua sala, alunos de Educação Especial e Inclusiva? \\
\hline Questão 3 & Esse(s) aluno(s) tinha um(a) professor(a) apenas para ele(s)? \\
\hline Questão 4 & $\begin{array}{l}\text { Você conviveu ou convive com alguém que é portador de alguma } \\
\text { necessidade especial? }\end{array}$ \\
\hline
\end{tabular}




\begin{tabular}{|l|l|}
\hline Questão 5 & Onde você conviveu ou se relacionou com essa(s) pessoa(s)? \\
\hline Questão 6 & $\begin{array}{l}\text { Em algum momento você já se incomodou com a presença de pessoas } \\
\text { portadoras de necessidades especiais? Explique a sua resposta. }\end{array}$ \\
\hline Questão 7 & $\begin{array}{l}\text { Como é o andamento das aulas quando o aluno portador de necessidades } \\
\text { especiais está presente? }\end{array}$ \\
\hline Questão 8 & $\begin{array}{l}\text { Como você, seus colegas e sua escola tratam os alunos portadores de } \\
\text { necessidades especiais? }\end{array}$ \\
\hline Questão 9 & $\begin{array}{l}\text { Você acha que é importante para os alunos portadores de necessidades } \\
\text { especiais estarem incluídos no ambiente escolar? Justifique. }\end{array}$ \\
\hline
\end{tabular}

Fonte: Autoria própria (2020).

Logo na primeira questão, já fui surpreendida pelo fato de o aluno 4 não se lembrar se havia em sua escola algum aluno com deficiência, sendo que, como dito acima, há, em sua turma, 3 destes alunos. Acredito que tal resposta tenha acontecido por desatenção, pois, na pergunta seguinte, os alunos participantes, incluindo o aluno 4, disseram que há ou já houve em sua sala alunos com deficiência.

Outra análise interessante possibilitada pelo questionário foi relacionada à convivência com pessoas com deficiência. Ao serem questionados sobre o fato de conviverem ou já terem convivido com pessoas com deficiência, apenas dois dos alunos responderam que convivem. Dessa forma, ficou claro para nós que todos consideram a escola um ambiente de convivência com essas pessoas.

No que diz respeito à questão na qual os alunos são perguntados sobre sentirem algum incômodo na presença de pessoas com deficiência, os alunos se posicionaram com respostas como "não porque eles também são normais" ou "não, eu não sinto problema com isto". Essas respostas revelaram que todos os alunos não se incomodam com a presença de pessoas com necessidades especiais. Já na sala de aula, apesar de não verem diferença no andamento das aulas quando há a presença de alunos com deficiência, o aluno 2 respondeu que "Geralmente, a maioria dos professores os ignoram. Então, o andamento é sempre o mesmo, eles estando presentes ou não.”. Tal crítica se faz válida e reforça a minha vontade de mudar minha prática com todos os alunos e a motivar outros colegas a implementarem essa alteração, o que pode ser feito por meio da observação das necessidades desses estudantes e do preparo das aulas de forma a ajudá-los no seu processo de ensino-aprendizagem.

Por meio da análise das respostas dadas à questão 8, fica claro que os alunos, no geral, se dividiram quanto ao tratamento dos colegas em relação aos alunos com deficiência, disseram 
que há aqueles que os tratam bem, e outros que fazem brincadeiras e praticam bullying, como se pode notar na resposta do aluno 2, dizendo que "Sempre tem aqueles que julgam os outros por serem diferentes mas eu tento tratar eles normalmente independente de qualquer coisa.”.

A resposta à última questão revelou unanimidade de posicionamento entre os estudantes: todos os alunos acham importante a inclusão dos alunos com deficiência no ambiente escolar, seja porque é direito deles, seja para ajudá-los a adquirir conhecimento, ou, ainda, para não se sentirem excluídos dos outros. Nas palavras do aluno 2, a inclusão dos alunos com deficiência é importante para eles "terem conhecimento, poder aprender e estudar como todos os outros alunos, por mais que seja do jeitinho deles, não se sentirem excluídos nem diferentes, entre outros...". Já o aluno 1 diz que "Independente da deficiência eles possuem o direito de participarem de tudo assim como nós.".

A aplicação do questionário foi muito importante, uma vez que pude observar que, além dos pensamentos e opiniões que os alunos já tinham, as reflexões propostas anteriormente já causavam algum impacto nesses pensamentos, uma vez que a questão da inclusão deixou de ser abordada por eles apenas como forma de acolhimento e acessibilidade. Nos módulos 1 e 2, a maioria das reflexões feitas pelos alunos eram relacionadas à forma de tratar as pessoas com deficiência, à importância em aceitá-las sem preconceito, a formas de facilitar seu acesso a todos os lugares, fazendo com que elas fossem menos dependentes de outras pessoas. Durante nossas conversas, o ambiente escolar como um espaço de inclusão, também era visto apenas dessa forma, como um ambiente de acolhimento e sociabilização, não como um espaço onde esses alunos pudessem desenvolver seu processo de aprendizado. Em uma das atividades discutidas no módulo 2, o aluno 5 disse que "os deficientes, muitas das vezes, precisam do nosso apoio e ajuda" e que "a sociedade não inclui as pessoas com deficiência (social e acesso), pois não dão a devida importância para o tema.".

Através da aplicação do questionário, não ficou claro se os alunos estavam considerando apenas a deficiência física ou se também consideraram a deficiência cognitiva. Em suas respostas, não havia detalhes para que isso fosse confirmado ou não, com exceção do aluno 1 , respondendo que convive na sua casa com a bisavó que não tem o movimento das pernas. Essa análise inconclusiva fez com que a escolha dos textos a serem trabalhados nos módulos seguintes envolvessem não só a deficiência física, mas também a deficiência cognitiva, de modo a desenvolver o olhar dos estudantes com relação às deficiências e à inclusão.

Para encerrar a etapa 2, o módulo 4, intitulado "Da temática ao gênero entrevista", contou com o estudo de um texto do gênero entrevista, criando uma ponte para a próxima etapa. Neste módulo, o objetivo era, além de dar continuidade à reflexão sobre a educação especial e 
inclusiva, explorar algumas características do gênero textual entrevista. O texto intitulado " $\mathrm{A}$ teoria nem sempre dá conta", publicado no site da Revista Nova Escola, foi reconhecido por 4 alunos como pertencente ao gênero textual entrevista pelo seu formato estruturado em perguntas e respostas. Porém, o aluno 2 ficou na dúvida sobre o texto ser uma entrevista ou uma reportagem, não sabendo justificar o porquê, mas ressaltando que o formato do texto era muito semelhante ao do texto que trabalhamos sobre o videogame. Nesse momento, ressaltei que a colocação era coerente, pois havia sim semelhanças entre os dois textos, como o trecho inicial que trazia algumas informações sobre o tema que seria abordado ao longo do texto e sobre quem falaria de tal tema, de ambos apresentarem a estrutura de pergunta e resposta, bem como outras características mais comuns como título e imagens com legendas. Ao final da discussão, os alunos chegaram à conclusão de que a melhor classificação para o gênero do texto era a entrevista, uma vez que o trecho com perguntas e respostas ocupava o maior espaço do texto e também era a parte mais importante, com as informações dadas de forma mais completa do que as que apareciam no parágrafo inicial do texto.

Ao fim do módulo, vimos um vídeo intitulado "Inclusão - O que as escolas precisam mudar?", disponível no canal da Nova Escola no YouTube, sobre os recursos que a escola precisa ter para ser uma escola adaptada e inclusiva. $O$ vídeo trazia uma exposição do cotidiano de uma professora portadora de necessidades especiais que atuava na sala de recursos e foi utilizado para ampliar o que foi discutido na entrevista, uma vez que abordava diversos recursos que as escolas precisam possuir para que sejam realmente inclusivas, finalizando o objetivo de ambientação e reflexão sobre a inclusão de pessoas com deficiência, com foco no espaço escolar. A atividade desenvolvida limitou-se a aspectos de compreensão textual e a relação temática entre o vídeo e a entrevista da atividade anterior. Discutimos sobre como é a realidade da nossa escola em relação a esses recursos. Os alunos observaram que, em geral, as escolas precisam vencer muitos obstáculos para atender às necessidades de todos os alunos com deficiência.

A seguir, falaremos um pouco sobre a terceira etapa da intervenção cujo foco foi o gênero textual entrevista.

\subsubsection{Terceira etapa: Gênero textual entrevista - um passeio entre as modalidades oral e escrita}

A etapa 3 teve como objetivo o estudo do gênero textual entrevista nas modalidades oral e escrita. Ao longo desta etapa, os al unos puderam refletir sobre a estrutura do gênero, sobre 
suas características, sua função comunicativa, dentre outros aspectos. Vale destacar que, nessa etapa, os alunos começaram a desenvolver seus conhecimentos acerca do processo de retextualização, uma vez que foram guiados a refletir sobre o fato de que o gênero entrevista pode ser primeiramente produzido na modalidade oral e retextualizado para a modalidade escrita, por exemplo. Dessa forma, as atividades elaboradas para essa etapa abordaram aspectos relacionados ao gênero textual entrevista, além de reflexões sobre os processos envolvidos na realização de uma entrevista oral para sua publicação escrita.

Esta etapa foi realizada ao longo de 26 aulas distribuídas em 3 módulos. Vale ressaltar que todos os módulos desta etapa se estenderam muito mais do que o planejado, uma vez que, apesar do número reduzido de participantes, as discussões sobre os textos e as reflexões feitas ao longo das atividades duraram mais do que eu havia previsto. Apesar de inesperado, essa foi uma grata surpresa já que os alunos se mostravam sempre empenhados e dispostos a participar. Creio que o fato de eles estarem distantes fisicamente uns dos outros e da escola fazia com que nossos encontros fossem mais aproveitados ainda por eles, não só como um espaço de aprendizado, mas também como um espaço de interação, já que o distanciamento social impedia as aulas presenciais. Além disso, os alunos também utilizavam o espaço das nossas aulas para sanarem dúvidas quanto ao desenrolar do ano letivo de 2020, indagando sobre questões como pontuação, carga horária, uso do aplicativo, entre outras.

O módulo 1 desta etapa, intitulado "Reconhecimento do gênero textual entrevista na modalidade escrita", teve o objetivo de levar os alunos a reconhecer a estrutura e as características do gênero entrevista na modalidade escrita. Através da análise e compreensão do texto Mão robótica inova a aprendizagem de Libras, publicado na página do Jornal do Joca, os alunos puderam explorar aspectos relevantes do gênero entrevista, embora ainda o confundissem com o gênero reportagem, o que justificavam pelo fato de o texto em questão apresentar informações que foram previamente pesquisadas. Nas palavras do aluno 2, "o texto é classificado como uma reportagem pois apresenta informações que a pessoa conseguiu através de pesquisa.". Nesse momento, perguntei aos alunos como acreditavam que uma entrevista era organizada, com o intuito de levá-los a pensar sobre todo o percurso que é feito até que se chegue, de fato, ao momento de executá-la. A reflexão foi muito produtiva, alcançando minha expectativa, pois os alunos apontaram que uma entrevista não é feita de forma aleatória, já que tem um tema determinado e se escolhe o entrevistado de acordo com o tema da entrevista ou ainda que, se o foco for na escolha do entrevistado, as perguntas são elaboradas com ênfase nele. Dessa forma, os alunos concluíram que o trecho do texto que antecede a entrevista é, em parte, construído por informações que são pesquisadas antes de a entrevista ser feita. Outro 
aspecto importante abordado nesse módulo foram os formatos que uma entrevista pode apresentar e os passos até que se chegue à publicação de uma entrevista no formato escrito. Em uma das questões, perguntei aos alunos o que era necessário para se produzir um texto como o que lemos. Todos os alunos se lembraram da entrevista no formato oral, citando suportes como rádio e televisão, também apontaram a plataforma YouTube e o gênero podcast como suportes de entrevistas. Quando passaram a apontar o que era necessário para se publicar uma entrevista na modalidade escrita, deram a ideia de fazer um passo a passo, que foi construído de forma coletiva pelos alunos. Ao todo, os alunos indicaram 23 passos, desde a escolha do tema ou entrevistado até a divulgação para o público-alvo. Desses passos, destaco 6 no quadro a seguir, por estarem relacionados ao processo de retextualização e a distinções entre retextualizar, revisar e reescrever.

Quadro 19: Alguns passos para a realização e publicação de uma entrevista escrita

1- Coletar informações sobre o tema e sobre o entrevistado;

2- Elaborar um roteiro de perguntas;

3- Gravar a entrevista por áudio ou áudio/vídeo;

4- Transcrever a entrevista;

5- Elaborar a introdução do texto (parágrafo que antecede a entrevista);

6- Revisar o texto final para publicação.

Fonte: A autora (2020).

O reconhecimento de passos, por parte dos alunos, que indicam operações que são utilizadas no processo de retextualização, faz-se relevante. Percebe-se que o processo de retextualização acontece, por exemplo, entre os passos 1 e 5 do quadro acima, uma vez que, nas palavras de Benfica (2013), são utilizados "diferentes textos-base" para a coleta de informações e, posteriormente, essas são transformadas em parte do texto que irá introduzir a entrevista escrita. Além disso, o processo de retextualização também é realizado entre os passos 3 e 4, já que, na passagem da entrevista na modalidade oral para a modalidade escrita, é necessário que algumas operações propostas por Marcuschi (2001) sejam realizadas, pois a simples transcrição do sonoro para o gráfico não cumpriria o objetivo final de publicação da entrevista escrita. Indagados sobre o que seria feito ao longo da transcrição, o aluno 1 disse "vai precisar de colocar os pontos", referindo-se aos sinais de pontuação; já o aluno 5 disse "às vezes, o entrevistado para de falar, pensa e fala outra vez, aí temos que escrever para ficar fácil de ler e entender". Nessas falas, percebe-se que os alunos, apesar de não saberem nomear tais operações, têm alguma noção do que precisa ser feito durante o processo de retextualização 
entre modalidades, mais especificamente nos aspectos de idealização e reformulação com as operações 1, 2, 3 e 4, que, em conjunto, "conduzem a uma primeira aproximação da idealização linguística" (MARCUSCHI, 2001, p.77).

Em relação ao passo 6, que trata da revisão do texto final, o aluno 3 comentou "precisamos ler o texto para ver se não tem erro antes de publicar", enquanto o aluno 1 disse que "tem que ver se tem palavra escrito errado, senão fica feio". Aqui, os alunos destacam a importância de revisar o texto e, consequentemente, reescrevê-lo caso seja necessário. Ressaltei a importância dessa atividade e perguntei se eles costumam fazê-la em suas produções. A resposta negativa não foi surpresa, nem quando o aluno 4 disse "só quando vale nota". Aproveitei o momento para mostrar a importância da revisão e da reescrita dos textos produzidos, pois, através dessas atividades, podemos melhorar nossa produção escrita, assim como observar os aspectos que nos causam maior dificuldade. Conforme aponta Benfica (2013), a revisão e a reescrita têm o objetivo de aperfeiçoar o texto para sua versão final, mantendo seu propósito comunicativo, ou seja, "são etapas do processo de refacção de um texto produzido, antes de sua publicação.” (BENFICA, 2013, s/n).

O módulo 2 foi direcionado ao estudo do gênero entrevista na modalidade oral e teve como objetivo observar e refletir sobre as semelhanças e diferenças de um mesmo gênero em diferentes modalidades da língua. Além disso, através das questões de interpretação textual, exploramos também aspectos da multimodalidade por meio da exploração da entrevista, especialmente naquela realizada oralmente. O texto analisado foi uma entrevista em vídeo, Entrevista com a super atleta paralímpica Paola Klokler, postada no YouTube, em que a atleta falava um pouco sobre como o esporte apareceu em sua vida e sobre suas conquistas no basquete. Ao longo das atividades de compreensão, vários aspectos foram levantados a fim de refletir e observar as diferenças entre a entrevista escrita e a entrevista oral. Logo na primeira questão, fui surpreendida pela colocação de um dos alunos sobre o registro utilizado na entrevista assistida. Ao responder que o vídeo era classificado como uma entrevista, o aluno 2 elencou, entre outros fatores, que se tratava de um texto formal e informal ao mesmo tempo, pois não havia "erros de palavras", como "ocê", mas o vocabulário utilizado não era "difícil" e o diálogo entre entrevistadora e entrevistada era "extrovertido". Nesse momento, houve uma grande oportunidade de abordar as distintas formas de registro e de modalidades dentro do gênero entrevista. Além disso, os alunos observaram alguns pontos levantados por eles no módulo anterior nas atividades de compreensão textual, como questões pré-estabelecidas para a entrevista, lembrando do roteiro de perguntas elaborado antes de realizá-la. 
A mudança nos turnos de fala também foi discutida durante as atividades e, além de destacarem a transferência do microfone entre os participantes, apontaram as pausas ao final das falas como o momento que indicava tal mudança.

Como um dos objetivos do módulo era apontar as semelhanças e diferenças entre as modalidades oral e escrita da entrevista, os alunos confeccionaram, de forma coletiva, um quadro que indicasse essas características nos textos analisados nos módulos 1 e 2 .

Quadro 20: Semelhanças e diferenças entre a entrevista escrita e a entrevista oral

\begin{tabular}{|c|c|}
\hline SEMELHANÇAS & DIFERENÇAS \\
\hline $\begin{array}{l}\text { - } \quad \text { Registro formal e informal; } \\
\text { - } \quad \text { Linguagem mista; } \\
\text { - } \text { Presença de entrevistador e } \\
\text { entrevistado; } \\
\text { - Estrutura de perguntas e respostas; } \\
\text { - Mudança do turno de fala } \\
\text { (entrevistador encerra a pergunta / } \\
\text { entrevistado dá a resposta). }\end{array}$ & $\begin{array}{l}\text { - Veículo de comunicação; } \\
\text { - Tema; } \\
\text { - } \quad \text { Modalidade (oral e escrita); } \\
\text { - } \text { escrita e perguntas surelaboradas para a } \\
\text { momento da entrevista para a oral; } \\
\text { - Interrupção na entrevista oral; } \\
\text { - Na entrevista escrita prevalece o } \\
\text { registro formal, enquanto na oral há os } \\
\text { dois tipos de registro. }\end{array}$ \\
\hline
\end{tabular}

Fonte: A autora (2020).

Vale destacar que as características apontadas pelos alunos no quadro, apesar de relacionadas aos textos dos módulos 1e 2 , são válidas para entrevistas escritas e orais de forma geral.

No módulo 3, intitulado "A entrevista - o processo de retextualização da modalidade oral para a modalidade escrita", a atividade desenvolvida foi dividida em duas partes. Em um primeiro momento, durante a aula, os alunos, conjuntamente, criaram um roteiro com perguntas sobre a inclusão de alunos com deficiência e a educação inclusiva que eram destinadas a membros da comunidade escolar, a fim de realizar uma entrevista oral e transformá-la em uma entrevista escrita a ser divulgada na página da escola no Facebook como parte de um projeto sobre Inclusão Social do qual a escola faz parte. Ao todo, os alunos criaram 12 perguntas (anexo A) envolvendo a temática e deveriam escolher 4 dessas perguntas para realizar a entrevista. Infelizmente, apenas os alunos 1 e 5 seguiram a orientação de realizar a entrevista de forma oral, através de áudios enviados pelo Whatsapp, prejudicando o objetivo incialmente pensado da atividade que era a retextualização entre as duas modalidades do gênero. Diversas foram as alegações, como a vergonha por parte dos alunos ou o pedido dos entrevistados para que as 
perguntas fossem respondidas por texto. Das duas atividades enviadas conforme o pedido inicial, percebi que as operações de idealização e reformulação foram aplicadas, com a inserção dos sinais gráficos de pontuação e a eliminação de pausas, hesitações e palavras repetidas. Além disso, os alunos 1 e 2 entregaram a entrevista escrita contendo título e parágrafo introdutório com apresentação do entrevistado antes da estrutura prototípica de pergunta e resposta (anexos B e C).

Durante a última aula deste módulo, após a entrega dos textos produzidos, tivemos uma conversa para compararmos os textos produzidos e observarmos quais se aproximaram mais do formato que vimos ao longo das aulas e o que deveria ser modificado naqueles textos que se distanciaram do formato visto. Como já mencionado, essa atividade foi dividida em duas partes: a primeira parte, que se refere à confecção do roteiro de perguntas, mostrou-se muito positiva, visto que os alunos elaboraram perguntas pertinentes ao tema abordado (inclusão de alunos com deficiência no espaço escolar) e ao perfil do entrevistado (membros da comunidade escolar). Além disso, a escolha das perguntas e dos entrevistados também alcançou a expectativa, visto que coletaram a opinião de professores, alunos e profissionais de saúde e educação sobre o tema. Em relação ao formato do texto entregue pelos alunos, todos estavam estruturados em perguntas e respostas, mas apenas dois apresentavam um parágrafo introdutório com uma apresentação do entrevistado e sobre a temática abordada na entrevista. Levando isso em consideração, percebi que a chamada de produção textual não deu conta da expectativa que criei para a entrega das atividades, uma vez que os alunos 3, 4 e 5 apontaram que, embora a orientação de realizar a entrevista oralmente estivesse clara, uma das orientações se tratava da transcrição da entrevista oral e, por isso, focando nessa orientação, devolveram apenas as perguntas feitas e respostas dadas. Tendo em vista as conversas que tivemos em sala e as atividades desenvolvidas, a minha avaliação foi de que os conhecimentos explorados em sala de aula quanto ao formato esperado da entrevista escrita poderiam não estar totalmente consolidados, uma vez que a apresentação da entrevista, o parágrafo introdutório, não apareceu em todas as produções desse módulo. Junto a isso, refleti, com base na conversa com os alunos, sobre a necessidade de, como professora, criar propostas de produção de textos com mais retomadas de conhecimentos anteriores e com um passo-a-passo ainda mais cuidadoso.

\subsubsection{Quarta etapa: Gênero textual reportagem}

A quarta etapa da intervenção teve como foco o estudo da estrutura e das características do gênero reportagem, sendo dividida em 4 módulos com a duração total de 20 aulas. Nesta 
etapa, os alunos puderam analisar o gênero em questão também nas modalidades escrita e oral, refletindo sobre as intencionalidades de uma reportagem, os sentidos delas advindos e suas características composicionais prototípicas - como manchete, subtítulo e lide, e de outras estruturas que podem contribuir para o objetivo e a compreensão do texto, como imagens, legendas e links. Além disso, os contextos de produção, circulação e recepção dos textos também foram analisados ao longo das atividades desenvolvidas, assim como a temática da inclusão de pessoas com deficiência continuou a ser refletida através dos textos utilizados.

O módulo 1, intitulado "Reconhecimento do gênero textual reportagem", teve como objetivo reconhecer as estruturas e características do gênero textual reportagem. Nesse módulo, usamos o texto $O$ ensino remoto e as crianças com deficiência: elas foram esquecidas?, publicado no site Canguru News. O engajamento dos alunos na discussão e reflexão do texto foi ainda maior devido à temática abordada, uma vez que, segundo eles, não só os alunos com deficiência foram esquecidos durante o ensino remoto, mas eles também. Segundo o aluno 2, “esse ano só vamos aprender com as aulas da intervenção, porque as respostas dos PET's estão todas na internet, é só copiar e colar”. Assim, a discussão foi também em tom de desabafo dos estudantes diante da situação do ensino remoto e de promoção de conscientização, mediada pela professora, com relação às formas de se organizar e estudar remotamente. Foi muito interessante observar a preocupação deles com os alunos de forma geral, já que apontaram diversas dificuldades enfrentadas por muitos como o acesso à internet e a instrumentos para a realização no ensino remoto, como computador e celular, sendo mais um momento para que os alunos desenvolvessem seu pensamento crítico acerca desse tema.

Em relação à classificação do gênero textual, os alunos ficaram na dúvida entre notícia e reportagem. Optei por, já nesse momento, tratar de características do gênero notícia que a diferenciam da reportagem e levá-los a observar como o texto lido se diferenciava do que havia dito. Apesar de ter consciência de que o ideal seria dedicar mais tempo para analisar e observar textos que se encaixassem nos dois gêneros textuais em questão, o ano letivo já estava chegando ao fim e havia outras prioridades na intervenção. A conversa foi proveitosa e os alunos conseguiram apontar algumas diferenças como a extensão do texto, a temática mais abrangente da reportagem e um acontecimento isolado na notícia, assim como apontaram semelhanças como o título em destaque e o subtítulo/linha fina.

Outro ponto importante desse módulo foi a análise de estruturas que apareceram no texto lido e que contribuíram para sua compreensão, como os links - que a princípio os alunos não apontaram como pertencentes ao texto - as imagens com suas respectivas legendas e os subtítulos que dividiam o texto em assuntos mais delimitados. Para os alunos, a presença dos 
links e imagens são indiferentes, não fazendo falta para a compreensão, caso fossem retirados. Já a divisão do texto em partes através dos subtítulos foi apontada como um facilitador para a compreensão, "cada parte ajuda a gente a entender um pouquinho sobre o assunto e a gente não confunde as informações", disse o aluno 2.

Para finalizar, as atividades do módulo 1 introduziram a questão do uso do discurso citado, tópico da etapa seguinte. Os alunos tiveram mais facilidade para identificar diferentes vozes no texto quando apareciam através do discurso direto por meio de citação, indicando o uso das aspas para a marcação dessas vozes, e dos verbos que apareciam ao final das citações. Já os trechos no formato de discurso indireto causaram nos alunos a dúvida se tal trecho era do autor ou não. Além disso, apenas o aluno 1 conseguiu apontar o porquê do uso de outros discursos na reportagem, "essas vozes mostram opiniões sobre o tema ou pessoas envolvidas com o tema e que tenham mais conhecimento sobre".

O módulo 2, intitulado "Estrutura e características do gênero reportagem", teve o objetivo de ampliar os conhecimentos sobre a estrutura e as características da reportagem, além de consolidar a presença de outras vozes no texto como um fator pertinente e recorrente nesse gênero textual. No texto Chegou a hora de mover a inclusão para frente, publicado na página Revista Digital Veja, foram analisados os contextos de produção, circulação e recepção do texto e as estruturas já sinalizadas no módulo anterior, como manchete, subtítulo/linha fina, lide, imagens, legendas e link. Nesse módulo, houve a possibilidade de retomar e consolidar muitas questões discutidas no módulo 1. Apesar de acharem o texto mais difícil do que o analisado anteriormente, os alunos foram mais seguros em suas colocações sobre as características da reportagem e sua estrutura. Segundo o aluno 3, o texto da Revista Veja "é maior para analisar e mais difícil por falar sobre leis e a gente não tá acostumado com esse tipo de texto".

No módulo 3, intitulado "Comparação entre textos - diferentes reportagens", voltamos aos textos analisados nos módulos 1 e 2 com o objetivo de comparar os textos lidos. O intuito era de que os alunos percebessem quais estruturas apareciam em ambos os textos, sendo características inerentes ao gênero reportagem, como manchete, subtítulo/linha fina e lide, e quais características estavam apenas em um dos textos, sendo características caras ao gênero reportagem, embora não obrigatórias para sua construção, como imagens, links e outras. Fiz algumas perguntas ao longo da construção do quadro comparativo, a fim de guiar os alunos. $\mathrm{O}$ resultado foi além do esperado, uma vez que os alunos conseguiram apontar tanto as estruturas semelhantes, quanto as que se diferenciavam, além de indicarem as diferenças relacionadas à produção, circulação e recepção dos textos, como o público-alvo, a intenção comunicativa e o veículo de comunicação de cada um dos textos. 
No último módulo dessa etapa, "Um passeio entre modalidades - da reportagem oral para a reportagem escrita, no processo de retextualização", a atividade proposta envolvia a retextualização de uma reportagem oral veiculada pelo Jornal Nacional (Globo Play), intitulada Educação inclusiva traz beneficios enormes para todos os alunos, em uma reportagem escrita para ser postada na página da escola no Facebook, junto com outros textos sobre educação inclusiva. Percebe-se nos textos dos alunos 1 e 2 (anexos D e E) que, em sua construção, apresentam as três estruturas prototípicas do gênero reportagem observadas ao longo da intervenção: manchete, subtítulo/linha fina e lide. O texto produzido pelo aluno 2 (anexo 5) além de apresentar outras características da reportagem, como as imagens, embora sem legendas, mostrou que autor teve mais cuidado com a estética do texto, pensando no seu contexto de circulação. Outro fator que me chamou a atenção nas retextualizações (anexos 4 e 5) foi a presença do discurso citado através de citações diretas. A etapa seguinte foi mais enfática com o trabalho com o discurso citado no gênero reportagem. Creio que a observação dos textos trabalhados ao longo da etapa 4 e a reflexão de algumas atividades que abordavam o uso de diferentes vozes no texto e sua importância na reportagem contribuiu para que, já nessa produção, o discurso citado fosse utilizado.

Em relação às operações de retextualização, percebemos que, mais uma vez, as operações de idealização e reformulação foram utilizadas, com destaque para o aluno 2 (anexo 5), em sua tentativa de inserção de paragrafação no texto.

A seguir, faremos a descrição e a análise de algumas atividades da etapa 5 sobre o uso do discurso citado e última etapa antes da realização da produção final.

\subsubsection{Quinta etapa: O discurso citado no gênero textual reportagem na modalidade escrita}

A etapa 5, "O discurso citado no gênero textual reportagem na modalidade escrita", foi composto por 3 módulos, em um total de 23 aulas. Nesse módulo, o foco da intervenção foi o estudo do discurso citado, nas formas direta e indireta, e seu uso na construção do gênero reportagem. O módulo 1, "As vozes presentes no texto", teve o objetivo de consolidar a identificação de outros discursos presentes em textos do gênero reportagem e observar a forma como tais discursos eram utilizados. Por meio do texto utilizado nesse módulo, Esporte é fonte de inclusão para jovens com deficiência, publicado na página Jornal do Joca, começamos com a reflexão sobre a temática da inclusão e como a escola contribui para que ela aconteça dentro e fora dela, analisamos a estrutura da reportagem e suas características, observamos a construção do texto através de seus contextos de produção, circulação e recepção e, por fim, 
voltamos nosso olhar aos discursos presentes no texto, à forma como eles são inseridos na reportagem e à relevância de seu uso para a intenção comunicativa do texto e para a construção do seu sentido.

Em relação à análise dos aspectos relacionados ao gênero reportagem, os alunos mostraram haver consolidado os conhecimentos quanto às características composicionais do gênero. Nas atividades relacionadas ao uso do discurso citado, como já havia sido introduzido no final do módulo anterior, o resultado também foi produtivo. Em uma das atividades, na qual os alunos compararam trechos do texto em que o autor fazia uso do discurso de outra pessoa, de forma direta e de forma indireta, os alunos responderam que havia discurso de outra pessoa nos trechos destacados, mas de maneiras diferentes. Segundo o aluno 1, "o trecho 1 tem o uso das aspas para separar uma fala que não é do autor e no trecho 2 o autor usou as palavras conta e diz para mostrar que era a voz de outra pessoa"; já o aluno 2 respondeu que "no trecho 1 é como se a própria pessoa tivesse falando, o repórter reproduz a fala, no trecho 2, o repórter conta o que a pessoa disse".

Para sistematizar tais reflexões, a última atividade do módulo foi dividida em três partes. Primeiro os alunos responderam como cada um dos trechos se caracterizava em relação ao uso do discurso citado; em seguida, os alunos reescreveram os trechos, aplicando as características apontadas no trecho distinto e, por fim, explicaram quais modificações foram feitas na reescrita do novo trecho. A expectativa era de que os alunos já apontassem os aspectos de cada tipo de discurso ao responder como os trechos se caracterizavam, mas isso não aconteceu. Para caracterizar os discursos usados, os alunos repetiram as respostas que deram na atividade anterior, ressaltando apenas o uso das aspas e dos verbos utilizados nos trechos destacados. A transposição dos trechos para as formas direta e indireta do discurso foi feita de forma eficiente pelos alunos, com ressalva para o aluno 4 que, além das aspas, separava o discurso direto por travessão. Na última etapa da atividade, os alunos foram levados a refletir sobre os aspectos linguísticos usados na transposição, explicando as modificações feitas. Três aspectos foram levantados pelos alunos: a pontuação, os verbos e a mudança de pessoa do discurso. Um dos alunos explicou: "onde o verbo era primeira pessoa, eu coloquei terceira; e, onde era terceira, eu coloquei primeira".

No módulo 2, "Os discursos direto e indireto", a reportagem Desafios na inclusão dos alunos com deficiência na escola pública, publicado na página Nova Escola Gestão, foi analisado conforme o texto do módulo anterior. Além das características e estruturas analisadas no módulo anterior, nesse módulo também analisamos o infográfico presente no texto como um item que pode contribuir para a compreensão do sentido da reportagem, ampliando seu 
conteúdo ou trazendo informações complementares. Depois da leitura do texto, refletimos sobre aspectos como credibilidade e veracidade das informações dadas pelo autor, relevantes ao uso do discurso citado no texto, sobre a escolha pelo discurso direto ou indireto e sobre a escolha dos verbos dicendi e seus significados condizentes com a intenção do discurso utilizado. Todos os alunos responderam que, ao usar outros discursos, o autor do texto busca comprovar sua fala, através de pessoas que têm alguma relevância dentro da temática abordada. Nas palavras do aluno 1, "não é a primeira vez que Maria Teresa Mantoan aparece nas nossas leituras, ele é alguém importante para a inclusão, por isso o repórter usa a fala dela no texto". Em relação à escolha pelo discurso direto ou indireto, o que mais me chamou a atenção foi a fala do aluno 2 , “o repórter fala o discurso do outro com as suas palavras para ficar mais fácil para o leitor", explicando que o repórter pode usar palavras mais fáceis, dependendo do público leitor. A análise foi interessante e surpreendente, uma vez que, inicialmente, ao elaborar estas atividades, eu havia pensado apenas na questão do tom de credibilidade que a presença do discurso do outro oferece ao texto. Com isso, pudemos conversar também sobre as adaptações lexicais relacionadas à transposição dos discursos.

Por fim, os alunos construíram coletivamente um quadro com as características do discurso direto e indireto, a partir da observação de exemplos do texto lido.

Quadro 21: Características mais comuns do discurso direto e do discurso indireto

\begin{tabular}{|l|l|}
\hline \multicolumn{1}{|c|}{ DISCURSO DIRETO } & \multicolumn{1}{|c|}{ DISCURSO INDIRETO } \\
\hline - Segue fielmente o que foi dito por quem está & - A reprodução não é fiel, o autor usa o \\
sendo citado; & discurso do outro com as suas palavras; \\
- Uso das aspas para marcar o discurso & - Não há sinais de pontuação para marcar o \\
citado; & discurso; \\
- Uso da primeira pessoa nos verbos e & - Uso da terceira pessoa nos verbos e \\
pronomes; & pronomes; \\
- Uso de verbos para indicar o discurso, & - Uso de verbos para indicar o discurso; \\
podendo introduzi-lo ou finalizá-lo. & - Uso da palavra QUE para introduzir o \\
& discurso. \\
\hline
\end{tabular}

Fonte: A autora (2021).

Percebe-se que os aspectos abordados pelas atividades da intervenção e retomados pelos alunos na construção do quadro estão de acordo com os aspectos observados na análise da 
produção inicial (tabela 1). Esse fato nos mostrou que a intervenção proposta apresentou resultados positivos quanto ao reconhecimento dos usos dos discursos, suas formas e funções.

O último módulo, "A transposição dos tipos de discurso", teve o objetivo de fixar as escolhas feitas ao transpor trechos que estão no discurso direto para o discurso indireto e viceversa. Para essa atividade, foram selecionados trechos dos textos trabalhados ao longo da intervenção e foram observados não só os aspectos presentes na análise da produção inicial, mas também sobre o uso dos dêiticos envolvidos na mudança de discurso, sobre a escolha do léxico, mais especificamente, do verbo a indicar o discurso e sobre o tempo verbal utilizado e as alterações que pode sofrer nessa transposição. Essa atividade foi fundamental para sensibilizar os alunos quanto à escolha dos verbos no discurso citado indireto e ao propósito das escolhas lexicais, visto que elas podem dar mais clareza àquilo que foi dito. No geral, os alunos souberam utilizar os dêiticos de forma correta e os alunos usaram com autonomia os pronomes relacionados ao detentor do discurso utilizado no texto. Além disso, a flexão dos verbos também foi feita de forma adequada nos processos de transposição de um discurso a outro.

Assim, encerramos a aplicação das etapas da intervenção que antecederam a produção final.

\subsubsection{Sexta etapa: Colocando os conhecimentos em prática (Produção final)}

A etapa 6, intitulada "Colocando os conhecimentos em prática", foi composta por apenas uma atividade: a produção final. Essa produção foi proposta com o objetivo de consolidar conhecimentos de questões exploradas durante a intervenção e fazer circular os textos dos alunos. Para a pesquisa, a produção final foi usada também com o objetivo analítico, em que se desejava observar os ganhos em relação aos conteúdos abordados ao longo da intervenção e aspectos que ainda requerem reflexão para serem concretizados com os estudantes.

A chamada de produção final foi uma proposta de retextualização na qual os alunos deveriam se basear em diferentes textos-base para a produção de uma reportagem sobre a temática da educação inclusiva, para que trechos de suas produções fizessem parte de uma matéria do jornal local. Dentre os textos-base que os alunos poderiam utilizar, estavam todos aqueles que foram utilizados ao longo da intervenção, textos pesquisados por eles, além das entrevistas produzidas pelos alunos durante a etapa 3 da intervenção, sendo o último um textobase de uso obrigatório, a fim de observar não só as operações de retextualização, mas também 
a forma como os estudantes fariam uso do discurso citado em suas produções. Essa etapa durou 3 aulas e contou com a presença de 4 alunos.

A princípio, iríamos traçar um comparativo quantitativo e qualitativo entre a produção inicial (diagnóstica) e a produção final, com o intuito de verificar o desenvolvimento dos alunos no que concerne ao processo de retextualização, à produção do gênero reportagem e ao uso do discurso citado na produção textual. Porém, devido ao contexto da intervenção, uma análise quantitativa da produção final e a consequente comparação quantitativa com a produção inicial não foi possível de ser realizada, uma vez que apenas 4 dos 5 voluntários entregaram a produção final, sendo 2 deles alunos oriundos de outra escola, não participando da etapa 1 de produção inicial. Sendo assim, optamos por analisar apenas qualitativamente as 4 produções, observando os aspectos abordados ao longo das etapas de intervenção. Traçaremos também, um breve comparativo entre as produções dos 2 alunos que participaram de toda a intervenção, através de suas produções inicial e final. Desse modo, todos os instrumentos de análise foram analisados de forma qualitativa ao longo da intervenção e apenas a produção inicial foi analisada de forma qualitativa e quantitativa.

Iniciamos nossa análise com os textos dos alunos 3 e 5 que não eram matriculados na turma no momento da produção inicial. O texto transcrito abaixo não é a versão final, mas a primeira escrita da produção final. Veja-se a produção final do aluno 3 a seguir:

Quadro 22: Produção final - exemplo 15 (aluno 3)

Inclusão Escolar
Inclusão das pessoas portadoras de necessidades especiais.
Por, xxxxx
Conversamos com, Thaísa Letícia de Souza Santos, sobre inclusão das pessoas portadoras de
necessidades especiais, confira abaixo:
Nós, conversamos com a Thaísa Letícia, e perguntamos o que ela achava que deveria ser feito
quando o aluno com deficiência sofre bullying.


Ela disse que, "Em primeiro lugar ir em um responsável da escola, pois isso é uma coisa muito séria, e não se deve brincar com isso."

Conversamos também sobre, o que fazer quando o aluno com deficiência tem um comportamento agressivo.

"Primeiramente, sentar com ele e conversar para ver o que está acontecendo, se está passando por algum problema familiar, segundamente, chamar os responsáveis desse aluno para conversar, para ver se está acontecendo alguma coisa em casa, ou se está sofrendo alguma coisa na família.” Afirma Thaísa

Perguntamos a ela também, sua opinião sobre, se ela acha que os alunos com deficiência são incluídos nas atividades da escola.

"Depende, pois a maioria dos alunos tem preconceito e comentem bullying, e não deixam o aluno participar, e alguns professores colocam outras atividades para o aluno com deficiência fazer." Disse, Thaísa

E por último, perguntamos a Tháisa o seu ponto de vista, de como os alunos com deficiência são tratados.

"Bom, na maioria das vezes os alunos com deficiência são tratados com indiferença na escolas, por conta de sua deficiência."

Fonte: A autora (2021).

Percebe-se que a produção do aluno 3, apesar de não apresentar a estrutura textual prototípica das reportagens escritas que foram trabalhadas ao longo da intervenção, atendeu o processo de retextualização solicitado na chamada de produção final, uma vez que o aluno não estrutura o seu texto no formato pergunta/resposta típico do gênero textual entrevista. A retextualização feita pelo aluno apresenta uma estrutura que se aproxima principalmente da reportagem jornalística televisiva, por meio da qual algum ou alguns especialistas sobre um determinado assunto vão expressar suas opiniões e pensamentos acerca da temática em questão. Tal análise é confirmada pela expressão “conversamos com” usada pelo aluno 3 ao iniciar seu texto.

Além disso, podemos observar a presença de outros aspectos pertinentes à construção da reportagem e que foram estudados ao longo no processo de intervenção, como a manchete "Inclusão Escolar", que informa ao leitor o principal tema abordado no texto e o subtítulo/linha 
fina "Inclusão das pessoas portadoras de necessidades especiais", apresentando um recorte da temática. Outro aspecto que nos chama a atenção é a construção do lide, pois, nele, o aluno indica informações relevantes para público-alvo, apresentando o convidado a falar sobre o assunto, mesmo que não indique seu papel dentro da comunidade escolar. O aluno retextualiza as perguntas feitas de forma indireta e utiliza o discurso citado para retextualizar as respostas do entrevistado. Por isso, concebe-se que a chamada para a produção textual não foi plenamente atendida, pois, embora a retextualização tenha acontecido entre modalidades, do gênero oral para o gênero escrito, e entre gêneros, da entrevista para a reportagem, o aluno se limitou a usar apenas um texto-base para sua produção. No aspecto relacionado à retextualização, percebemos que o aluno conseguiu aplicar as operações de idealização e reformulação desse processo, uma vez que há a inserção dos sinais gráficos de pontuação, a alteração de usos típicos da oralidade como "tá", retirada de termos repetidos e hesitações. Apesar dessas modificações, ainda encontramos problemas no texto, como a falta de paragrafação. Nesse caso, ao observar o texto digitado em blocos por espaçamentos, temos duas hipóteses: a possibilidade de tal divisão ter o intuito de separar o texto em parágrafos ou de manter cada pergunta em um bloco de texto diferente. Ressaltamos aqui a compreensão como um aspecto fundamental para o processo de retextualização, pois, como mencionado na fundamentação teórica, ela é estritamente necessária para que a retextualização, apesar das mudanças promovidas nos textos-base, mantenha o conteúdo abordado por eles. Cabe destacar que o processo de retextualização promove mudanças significativas no que se refere à estrutura do texto, modificando, além da modalidade e do gênero, seu objetivo comunicativo, seus contextos de produção, circulação e recepção, mas não o que é dito de fato. $O$ texto produzido pelo aluno 3 demonstra compreensão do que foi tratado no texto-base, a entrevista realizada, mantendo o conteúdo abordado tendo em vista seu novo propósito comunicativo. Pensando na estrutura do gênero reportagem, percebemos que houve ganhos por parte do aluno 3 em sua produção final.

Em relação ao uso do discurso citado, observamos que o aluno tem conhecimento sobre as características do discurso direto e indireto, uma vez que faz uso de ambos em seu texto, através da citação direta, com a reprodução do discurso de outra pessoa entre aspas, e através da introdução do discurso pelos verbos dicendi e de elocução. Ademais, um trecho chama a atenção por nele o autor mesclar características prototípicas de ambos os discursos, o que pode ter sido proposital, ou seja, o autor quis manter fielmente a fala do entrevistado: 
Quadro 23: Trecho de produção final - exemplo 16 (aluno 3)

Ela disse que, "Em primeiro lugar ir em um responsável da escola, pois isso é uma coisa muito séria, e não se deve brincar com isso."

Fonte: A autora (2021).

O aluno 3, ao utilizar o discurso do entrevistado, coloca-o entre aspas, indicando o uso do discurso direto, porém o uso do verbo de elocução, seguido da conjunção subordinada "que" indica a introdução do discurso indireto. Apenas nesse trecho encontramos essa mescla de características, pois, na reprodução das outras perguntas/respostas, o aluno 3 fez o uso mais canônico do discurso direto, introduzindo a fala do entrevistado entre aspas e finalizando o trecho com o verbo dicendi, apontando o discurso utilizado para seu autor.

Vale destacar que a mescla dos discursos direto e indireto nesse trecho chama a atenção por apontar para um novo paradigma em relação ao uso do discurso citado, o qual não havia sido discutido em sala e que, numa perspectiva tradicional de ensino dos diferentes discursos, não seria abordado, já que a visão de oposição entre formas do que comporia o discurso direto e indireto poderia levar a uma concepção de que apenas no discurso indireto figurariam verbo dicendi seguido de que, o que não daria conta da fluidez linguística presente no uso dos distintos discursos. As características dos discursos direto e indireto apontadas pela Gramática Tradicional (quadro 2) e também pelos alunos na montagem do quadro 7 são tipicamente utilizadas para cada um dos tipos de discurso, mas isso não significaria dizer que apontem para oposições ou obrigações de uso quanto às formas. Tal mescla de elementos típicos de cada um dos tipos de discurso aponta para uma confluência entre as características dos estilos do discurso citado e foi observada não só na produção final do aluno 3, mas também dos alunos 2 e 5 , como será analisado posteriormente.

Em relação às escolhas lexicais dos verbos, embora tenha havido pouca variação, em que se utilizaram apenas os verbos "disse" e "afirma", podemos afirmar que o aluno 3 os empregou de forma coerente com o que o discurso citado pretendia. Entretanto, o uso de verbos de escopo mais geral e comum pode ser justificado pela dificuldade na identificação de diferentes ações produzidas pela fala, como "opinar", "confirmar", "reiterar, "justificar" e outros, além de refletir, possivelmente, um escasso repertório de verbos relacionados à ação de falar.

No texto produzido pelo aluno 3, percebemos como a pontuação na construção do discurso direto e indireto precisa ser trabalhada com mais foco nas aulas, principalmente, o uso da vírgula e dos dois pontos, sinais fundamentais para a construção do discurso citado. Como a 
intervenção não priorizou a pontuação em nenhuma de suas etapas, vemos a necessidade de dar continuidade nesse trabalho e ampliá-lo, englobando tal aspecto.

Por fim, por meio da análise dessa produção, observamos a falta de exploração de elementos multimodais na produção da reportagem do aluno 3. Todo o texto é construído com a mesma fonte e tamanho, sem nenhum destaque, além da falta de elementos vistos na intervenção como presentes nas reportagens, tais quais imagens, gráficos e links. Podemos levantar duas possíveis justificativas para essa questão, sendo a primeira a tradição com a produção textual nas aulas de português arraigada ao texto escrito tradicional, e a segunda, ao desconhecimento no uso das ferramentas digitais.

Como professora pesquisadora, acredito que a tradição das produções escritas nas aulas de português interferiu mais no resultado dessa produção, pois, ao longo da intervenção, pude perceber que os alunos têm domínio suficiente para que utilizem a multimodalidade em suas produções. Ao longo das aulas, os alunos criaram figurinhas para Whatsapp com o rosto dos colegas e com o meu, incluindo frases ou palavras que nos caracterizavam, criaram montagens com fotos para serem usadas como perfil durante as aulas, levando-me a crer que sabem manusear bem as ferramentas digitais.

Analisando o texto do aluno 5, observamos que a estrutura, as características do texto e a forma como o discurso citado foi construído eram muito semelhantes ao que o aluno 3 utilizou em sua produção. Veja o texto do aluno 5 abaixo:

Quadro 24: Produção final - exemplo 17 (aluno 5)

\begin{abstract}
A inclusão escolar
Como funciona a escola inclusiva.

Conversamos com a psicopedagoga Adriana Lamas sobre a inclusão dos alunos com deficiência no âmbito escolar, foi perguntado a ela o que está sendo observado hoje sobre a realidade da inclusão escolar. Ela disse que "A inclusão escolar vem aos poucos ganhando espaço, mas ainda existe um pouco do despreparo do sistema regular. O que eu quero dizer com isso? É que há resistência de algumas escolas principalmente no âmbito privado na aceitação desses alunos com deficiência então isto precisa ser mudado, precisa ter uma outra roupagem para que essas crianças e adolescentes sejam aceitos e realmente se faça a inclusão, que a inclusão saia do papel."
\end{abstract}


Conversamos também sobre quais seriam os recursos necessários que todas as escolas deveriam disponibilizar para atender aos alunos com deficiência, ela disse que "Se faz necessário locais adequados, profisssionais especializados, eliminação de barreiras arquitetônicas e o respeito a individualidade de cada um."

Nos perguntamos qual é o seu papel no processo de inclusão dos alunos com deficiência. "Não só o meu papel mas o de todos os pares escolares é muito importante neste processo, para que se faça que a inclusão seja realmente inserida dentro da escola. E o que nós podemos fazer? Buscar valorizar as habilidades desses alunos, fazer com que eles se sintam parte realmente desse processo, fazer coisas diferentes, onde esses alunos que as vezes possuem dificuldades na escrita, na leitura e na fala, possam mostrar seus trabalhos (Pintar, tocar instrumentos, entre outros), então é importante que a escola promova dentro de suas possibilidades a apresentação desses trabalhos para que eles se sintam importantes, para que se trabalhe bem a autoestima deles, isso é inclusão. É como eu sempre digo, a inclusão vai além dos muros da escola pois é também uma proposta social." disse Adriana.

Por fim, perguntamos a ela sobre o que a escola pode oferecer para os alunos com deficiência. "Não só a escola mas a sociedade tem por obrigação oferecer recursos para essas pessoas, para que elas possam se sentir realmente incluídas."

Fonte: A autora (2021).

Observamos que todas as análises apontadas para a produção do aluno 3 podem ser indicadas para a produção do aluno 5 , desde a estrutura utilizada para a construção da reportagem, passando pela realização das operações de idealização e reformulação, até chegar aos aspectos analisados pelo uso do discurso citado. $O$ aluno 5 também demonstra conhecimentos acerca das características dos tipos de discurso, usando majoritariamente o discurso direto através da citação entre aspas, com apenas um trecho em que se encontram características do discurso direto e do discurso indireto de forma mesclada, como também acontece no texto do aluno 3.

Vale salientar que a chamada de produção final prezava pela retextualização entre gêneros, uma vez que a atividade de retextualização entre modalidades já havia sido feita na etapa 3. Apesar de não completamente construída no formato das reportagens escritas trabalhadas na intervenção, assumimos que a retextualização feita pelo aluno 5 foi realizada parcialmente por conter características prototípicas da reportagem, como a manchete "A 
inclusão escolar" e o subtítulo/linha-fina "Como funciona a escola inclusiva". Além disso, o primeiro parágrafo da reportagem produzida pelo aluno 5 apresenta o lide ainda mais completo quando pensamos no formato reportagem com o especialista, ao indicar que a conversa apresentada na construção do texto é uma psicopedagoga. Ainda analisando o processo de retextualização, conseguimos observar diversos ganhos no que se refere às operações de idealização e reformulação no processo de retextualização, bem como no uso do discurso citado. Destacamos, principalmente, as operações 1 e 3, com a eliminação das marcas interacionais, hesitações e palavras repetidas, além da operação 2 - inserção da pontuação, parcialmente alcançada. Assim como no texto produzido pelo aluno 3, o aluno 5 também demonstrou uma possível marcação de paragrafação do seu texto, dividindo-o por blocos relacionados às perguntas e respostas feitas no texto-base, formato relativamente comum no ambiente on-line. No que se refere ao processo de retextualização, a inserção da pontuação (operações 2 e 4), também observada na produção inicial, mostrou-se como um aspecto que ainda precisa ser refletido e consolidado. Durante as etapas da intervenção, esse aspecto foi pouco abordado, não só devido ao contexto de aplicação, mas também por falta de atividades que tivesse foco nesse aspecto.

Em relação ao uso do discurso citado, o que mais chama a atenção, além do reconhecimento das características dos discursos direto e indireto observados na análise do texto produzido, é também a mescla dos dois tipos de discursos no trecho a seguir:

Quadro 25: Trecho de produção final - exemplo 18 (aluno 5)

Ela disse que "A inclusão escolar vem aos poucos ganhando espaço, mas ainda existe um pouco do despreparo do sistema regular. O que eu quero dizer com isso? É que há resistência de algumas escolas principalmente no âmbito privado na aceitação desses alunos com deficiência então isto precisa ser mudado, precisa ter uma outra roupagem para que essas crianças e adolescentes sejam aceitos e realmente se faça a inclusão, que a inclusão saia do papel."

Fonte: A autora (2021).

Esse é mais um exemplo que comprova que a perspectiva tradicional de ensino dos diferentes tipos de discurso não dá conta do seu uso habitual não só nas produções escritas, mas também nas produções orais, ou seja, a presença de algum aspecto linguístico recorrente no uso do discurso indireto, como a conjunção integrante "que", não anula o uso do discurso direto feito através da citação direta. Os alunos usam desse formato "tradicionalmente não previsto" com autonomia em seus textos. 
Vale destacar também que, em relação ao uso do discurso no estilo indireto, os alunos 3 e 5 optaram por manter a fidedignidade dos discursos utilizados na composição de sua reportagem. Apesar de esse aspecto ser de fundamental importância, visto que os gêneros do campo jornalístico/midiático precisam manter sua credibilidade junto ao público leitor e essa seria uma das estratégias de fazê-lo, é possível revelar, ainda, que os alunos não sentem segurança em transpor os discursos de outra forma ou mesmo julgam que não seja necessário fazer isso. Além disso, a seleção dos discursos utilizados demonstra compreensão não só do assunto envolvido, mas também da leitura dos textos-base, recorrendo a escolhas favoráveis ao recorte escolhido para sua produção.

Por fim, ressaltamos que o aluno 5 também não faz exploração de outros elementos multimodais na construção da sua reportagem, fato que reforça a tradição escolar da produção estritamente escrita nas aulas de língua portuguesa.

Pensando em todo o cenário de aplicação e em todos os obstáculos enfrentados para que fosse realizada, acredito que o resultado para os alunos 3 e 5 tenha sido altamente positivo, uma vez que os textos entregues demonstraram ganhos em relação aos aspectos do processo de retextualização, da construção dos gêneros entrevista e reportagem e do uso do discurso citado na reportagem, todos abordados na intervenção. Com a análise das atividades feitas durante todas as etapas da intervenção, vemos que os alunos 3 e 5 consolidaram o conceito de retextualização através dos resultados de suas produções textuais, não apenas na produção final, mas também nas produções da entrevista escrita (etapa 3) e da reportagem escrita (etapa 4), ambas tendo como texto-base produções orais. Além disso, observamos a apropriação de conhecimentos no que concerne à estrutura da reportagem, tendo em vista elementos prototípicos do gênero, como a manchete, o subtítulo/linha fina e o lide. Em relação ao uso do discurso citado, a citação direta e o uso dos verbos dicendi e de elocução também podem ser destacados como aspectos positivos, uma vez que foram utilizados corretamente e recorrentemente nos textos produzidos, sempre creditando o discurso a seu real produtor. Ressaltamos que, apesar dos ganhos, há alguns aspectos que ainda precisam ser revistos, refletidos e consolidados, como a pontuação e o uso dos elementos multimodais.

Com relação aos textos produzidos pelos alunos 1 e 2, conseguimos não só analisar qualitativamente os ganhos relacionados aos aspectos abordados ao longo da intervenção, mas também traçar um comparativo entre os textos produzidos na produção inicial (anexos 6 e 7) e na produção final (anexos 8 e 9). Antes de traçar tal comparativo, faço uma análise geral no que se refere ao processo de retextualização proposto na chamada de produção final e atendido pelos respectivos alunos (anexos 6 e 7). Ambos os alunos entregaram a produção de uma reportagem, 
com as estruturas prototípicas do gênero, como manchete, subtítulo/linha fina, lide e corpo de texto, além de inserirem estruturas opcionais do gênero como imagem e link. Além disso, os alunos 1 e 2 utilizaram não só as entrevistas feitas na etapa 3, mas também outros textos utilizados ao longo da intervenção na construção da sua reportagem.

Já nos aspectos manchete e subtítulo percebemos a diferença no que se refere ao processo criativo e ao objetivo de cada uma dessa partes. Na produção inicial, o aluno 1 colocou apenas a seguinte manchete "O início do vídeo game", um título pouco provocativo para o leitor e sem a presença de um subtítulo com alguma informação relevante do que seria abordado ao longo do texto. Vejam-se tais aspectos na produção final do aluno 1.

Figura 5: Trecho de produção final - exemplo 19 (aluno 1)

\section{Nas escolas públicas como ocorre a educação inclusiva ?}

\section{As escolas públicas em geral possuem uma sistema de aprendizagem bem mediano porém como a inclusáo ocorre nestas escolas}

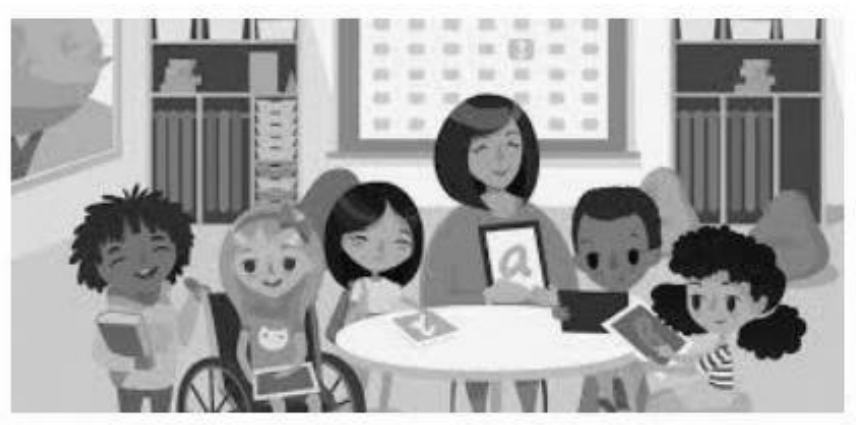

Fonte: A autora (2021).

Percebemos que, apesar de alguns desvios acerca do uso do padrão da língua, o aluno 1 inseriu em seu texto uma manchete em destaque que provoca o leitor através de uma questão a ser respondida pelo texto. Além disso, o aluno busca manter o interesse do leitor no subtítulo do seu texto, ainda em um tom de indagação. A escolha do conectivo "porém" dá indícios de haver inclusão na escola pública, visto que se opõe a ideia de "sistema de aprendizagem bem mediano" e a possibilidade de ocorrência da inclusão. É interessante notar que a formatação empregada (com texto centralizado, caixa alta na manchete, negrito) auxiliam na identificação do gênero e do formato mais prototípico dele. 
Ainda pensando na estrutura composicional do gênero, cabe destacar que o aluno faz uso de uma imagem que conversa com a temática do seu texto, indicando a inclusão de alunos com deficiência. Essa inserção marca uma característica relevante do gênero, reforçando seu aspecto multimodal. Observamos a falta de legenda para a imagem, que é fundamental, mesmo que a imagem seja autoexplicativa, sinalizando algo que ainda deva ser trabalhado com os alunos.

Outro aspecto relevante para a construção da reportagem são as informações presentes no primeiro parágrafo, chamado lide, com o intuito de introduzir o assunto que será detalhado ao longo do texto, ainda focando na atenção do leitor. Na produção inicial do aluno 2, o lide fica explícito nos dois primeiros parágrafos. Veja-se o trecho a seguir:

Quadro 26: Trecho de produção inicial - exemplo 20 (aluno 2)

Hoje vamos falar sobre o famoso VIDEOGAME e quem o criou. Em 1972 foi lançado no mercado o primeiro videogame que recebeu o nome de Magnavox Odyssey ou simplesmente Odyssey 100 pela empresa Magnavox, braço direito da Philips. O criador é um engenheiro alemão chamado Ralph Baer, que hoje aos 87 anos ainda disfruta de sua criação.

Fonte: A autora (2020).

Observamos que o aluno situa o leitor quanto ao tema (videogame), quem foi o criador e quando isso ocorreu. Apesar de iniciar o texto com "hoje", situando o momento, e "vamos", chamando o leitor a participar, não aborda alguma informação que possa provocar ainda mais o leitor, instigando-o à leitura. Já na produção final, o aluno 2 atrela a temática da educação inclusiva ao momento que estamos vivendo, a pandemia do coronavírus, e a consequente suspensão das aulas, o que se mostrou bastante interessante. Na reportagem intitulada "Alunos portadores de necessidades especiais em período de pandemia", o aluno inicia seu texto da seguinte forma: 
Quadro 27: Trecho de produção final - exemplo 21 (aluno 2)

Quando a pandemia do novo coronavírus se agravou em meados de março, as escolas fecharam e os educadores tiveram de se reinventar para garantir que todos os alunos tivessem acesso à Educação. Com isso veio muitos desafios, estudantes sem conexão com a internet $\mathrm{e}$ desmotivados, dificuldades para apresentar aulas online, dúvidas sobre como engajar e avaliar a turma, entre outros.

Fonte: A autora (2021).

O aluno 2 aborda, no primeiro parágrafo, o cenário das aulas on-line em tempos de pandemia, porém não menciona os alunos de necessidades especiais, induzindo o leitor a continuar sua leitura do texto para saber mais informações sobre aquilo que é sinalizado pela manchete e como tal informação se relaciona com o que está escrito no primeiro parágrafo do seu texto. Destaca-se o fato de que o recorte feito pelo aluno em relação à temática de educação inclusiva é muito pertinente e atual, não só porque a inclusão é um tema que tem sido amplamente discutido pela comunidade educacional nos últimos anos, mas também porque a inclusão se mostrou ainda mais difícil de ser realizada no contexto do ensino remoto, mostrando que a retextualização feita incorporou diferentes textos-base, o que foi positivo para a produção final e para a minha percepção quanto aos ganhos de informação e de compreensão do estudante sobre o tema. Durante a leitura e análise da produção final do aluno 2, percebemos várias informações que apareceram nos textos lidos e analisados ao longo da intervenção e também informações novas que contribuíram para a construção de sua reportagem.

Dessa forma, podemos dizer que o aluno alcançou com sucesso em sua retextualização a operação 9 - agrupamento de argumentos e condensando ideias -, uma vez que tal operação é uma estratégia significativa no processo de resumir e transformar os textos-base para a produção do novo texto. $\mathrm{O}$ aluno 2 selecionou dentre os textos-base as informações que eram mais pertinentes ao tema de sua reportagem, mantendo o maior volume de informações e o menor volume de texto, conforme aponta Marcuschi (2001).

Dos aspectos analisados desde a produção inicial, confirmamos com a análise da produção final do aluno 1 , o que já foi sinalizado nas produções dos alunos 3 e 5 , que as operações 2 e 4, relacionadas a inserção da pontuação, são problemáticas e ainda precisam ser consolidadas nas aulas de português. Veja um trecho a seguir:

Quadro 28: Trecho de produção final - exemplo 22 (aluno 1)

Apesar de algumas escolas serem iclusivas esse tema é muito pouco abordado nas escolas 
mais pobres ou menos informadas, este tema é muito importante ser abordado para que um dia estas crianças possam viver em um munso onde elas tambem importam igualmentes as outras crianças " A inclusão escolar vem aos poucos ganhando espaço, mas ainda existe um pouco do despreparo do sistema regular. O que eu quero dizer com isso? É que há resistência de algumas escolas principalmente no âmbito privado na aceitação desses alunos com deficiência então isto precisa ser mudado, precisa ter uma outra roupagem para que essas crianças e adolescentes sejam aceitos e realmente se faça a inclusão, que a inclusão saia do papel " Diz a Psicopedagoga Adriana Lamas .Apesar das dificuldades que estas escolas passam para conseguirem incluirem os alunos com deficiencia , no futuro proximo muito mais escolas iram se tornar inclusiva tornando o mundo mais inclusivo e um mundo amigo.

Fonte: A autora (2021).

Podemos perceber no trecho acima que o uso da vírgula, mais especificamente no que tange ao emprego associado ao uso do discurso citado, é um aspecto que precisa ser discutido e refletido com os alunos, pois ainda não foi consolidado em anos anteriores, nem no processo de intervenção. Como já mencionado, em nenhuma etapa, a pontuação foi abordada como foco ou como objetivo, mesmo sendo um dos aspectos observados na produção inicial. Sem dúvidas, meu olhar de professora e pesquisadora mostrou-se frágil quanto a isso. Acredito que, após a análise inicial, a mudança no contexto de aplicação influenciou nas escolhas que fiz para as atividades de intervenção, priorizando alguns aspectos e colocando de lado outros que julguei não tão importantes naquele momento. Contudo, poderei dar continuidade a essa intervenção com os mesmos alunos no ano de 2021, observando os aspectos já consolidados e olhando com mais prudência para esses aspectos ainda não consolidados.

Vale salientar que os alunos 1 e 2 utilizaram em suas produções estruturas opcionais do gênero reportagem, como a imagem e o link. Tais estruturas, apesar de não serem obrigatórias, são frequentes no gênero em questão, visto que colaboram e ampliam o tema e com os apelos de leitura. Além disso, os autores optaram por inserir o uso de links no texto, tais como é feito comumente em reportagens publicadas em sites. Assim, os alunos mostraram capacidade em delimitar conteúdos que estivessem diretamente ligados à sua temática, aplicando as operações de retextualização 7 e 8 - relacionadas ao fenômeno cognitivo da interpretação e compreensão textual-, possibilitando ao leitor novas leituras sobre o assunto.

Em relação aos aspectos apontados pela tabela 1, referentes ao uso prototípico do discurso citado, também vemos evolução nas produções realizadas pelos alunos 1 e 2 . 
O aluno 1, na sua produção inicial, mostrou conhecimento acerca da importância do uso do discurso citado na forma indireta, utilizando a $3^{\text {a }}$ pessoa do discurso, introduzindo-o através de um verbo de elocução acompanhado do conectivo "que", conforme o trecho a seguir:

Quadro 29: Trecho de produção inicial - exemplo 23 (aluno 1)

Bear afirma que sempre esta envolvido com a indústria de jogos e tem alguns que mais gosta como: pacman, pingue-pongue etc.

Fonte: A autora (2020).

$\mathrm{Na}$ produção final, o autor opta por empregar o discurso direto, incluindo-o no texto através do uso da citação direta, com o discurso utilizado para compor sua reportagem entre aspas.

Quadro 30: Trecho de produção final - exemplo 24 (aluno 1)

Além dos muitos desafios, a inclusão não depende apenas da escola estar preparada com equipamentos ou não estar ,uma escola inclusiva é algo feito em conjunto e é necessário um colaboração entre alunos , os professores os páis etc. "visto que muitas vezes nós professores temos dificuldades em trabalhar com esses alunos em relação as limitações de cada um, não temos a preparação certa para lidar com os mesmos. Já os outros alunos, acredito que acolhem bem os alunos de inclusão, acho que isso acontece de forma bem bacana e legal, mas algumas vezes os próprios alunos portadores de necessidades especiais, se retraem um pouco e não deixam os outros se aproximarem" Opina a professora Ana Caroline que trabalha na Escola Estadual Engenheiro Henrique Dumont ,que tenta ao máximo ser inclusiva a alunos com deficiências físicas e mentais.

Fonte: A autora (2021).

Observamos que o aluno 1 lançou mão da citação direta, colocando corretamente o trecho citado entre aspas, mantendo o uso da $1^{\text {a }}$ pessoa do discurso e finalizando-o com o verbo dicendi "opina", coerente com a intenção do discurso utilizado que era justamente apontar um pensamento acerca da forma como os alunos com deficiência são tratados pelos professores, colegas e por si mesmos. Assim, a citação direta foi inserida de forma a manter o sentido daquilo que vem sendo apresentado, houve a utilização das aspas para indicar a introdução direta do texto, opção por léxico que sinaliza adequadamente a circunstância de fala (“opina”) e, ainda, atribuição de fala à professora, denominando-a e caracterizando-a por meio de uma oração 
adjetiva. Isso mostra que o estudante progrediu em sua forma de referência e caracterização do entrevistado na reportagem, dando um caráter de maior informatividade e credibilidade para o texto.

Podemos observar como a ausência da vírgula ao final da citação reforça que a pontuação é um aspecto que ainda precisa ser concretizado pelos alunos. Como já mencionado, não houve um olhar analítico para esse aspecto durante as etapas da intervenção. As atividades desenvolvidas não tiveram foco na inserção da pontuação, que deverá ser abordada em futuras sequências didáticas elaboradas para essa turma. Mesmo assim, embora o uso de alguns sinais de pontuação seja uma dificuldade ainda a ser abordada, o adequado uso das aspas foi um ganho, assim como do discurso direto, uma vez que não havia sido utilizado pelo aluno $1 \mathrm{em}$ sua produção inicial.

O aluno 2 já havia demonstrado, na produção inicial, conhecimentos acerca do uso do discurso citado na forma direta e indireta, utilizando os dois formatos em seu texto. Veja-se no trecho a seguir:

Quadro 31: Trecho de produção inicial - exemplo 25 (aluno 2)

Único conselho que o engenheiro daria para qualquer pessoa em qualquer negócio é: "Não espere fazer um milhão rápido. Faça o que você faz melhor de melhor. Você vai ser feliz, e quem sabe até rico!"

Fonte: A autora (2020).

Percebemos que, nesse caso, o aluno 2 utiliza um verbo suporte dicendi, visto que a noção de "aconselhar" fica explícita por meio do uso do verbo suporte (dar conselho) de "único conselho que o engenheiro daria (...) é". Isso sinaliza mais uma forma de introdução do discurso direto um pouco diferente da prototípica e da qual, no cotidiano, nos valemos na construção dos textos. Na produção final, o aluno também faz uso da citação direta e o introduz a partir do verbo de elocução ("afirma") acompanhado da conjunção integrante "que”, mantendo o uso da pontuação introdutória (dois pontos) e sinalizadora da citação direta (aspas). 
Quadro 32: Trecho de produção final - exemplo 26 (aluno 2)

A professora de inglês na Escola Estadual Engenheiro Henrique Dumont (Polivalente), Ana Caroline de Meireles Silva, ou como muitos a conhecem, Teacher Carol, afirma que: "Essa é uma questão difícil, dado que nós estamos tendo uma certa dificuldade para atingir e contactar os alunos de um modo geral. Em nossa escola são as professoras de apoio, que estão entrando em contato com os alunos portadores de necessidades especiais, pois elas têm uma maior proximidade com eles. Geralmente elas passam as atividades para os responsáveis, que tentam fazer com os alunos. O ensino remoto fica muito limitado, as alternativas que nós temos é por ferramentas como o WhatsApp, vídeo chamadas, enfim, não vejo outras alternativas no momento!"

Fonte: A autora (2021).

Apesar de uma análise que envolveu um corpus pequeno, foi possível notar ganhos dos estudantes quanto à organização estrutural dos gêneros textuais entrevista e reportagem, uma vez que se valeram de apelos multimodais, diferentes textos, incorporaram e cruzaram diversificadas informações de fontes diferentes, mobilizando operações fundamentais para o processo de retextualização, seja entre modalidades, seja entre gêneros. No que se refere ao uso do discurso citado na construção da reportagem, os alunos observaram sua relevância não só para a construção do sentido do texto, mas também para dar credibilidade em relação ao tema abordado, apontando diferentes vozes que contribuem para a comprovação do seu posicionamento. Para tanto, valeram-se de diferentes formas de emprego do discurso citado, atribuíram adequadamente a autoria dos textos originais, caracterizaram o autor desses textos, inseriram em trechos da reportagem em que, de fato, o trecho era pertinente, mostrando compreensão do assunto e propriedade na construção dos textos.

A temática sobre inclusão de alunos com deficiência no espaço escolar foi amplamente discutida, refletida e acredito que consolidada pelos alunos. No que se refere à abordagem da temática nos textos desenvolvidos não só na produção final, mas também em outros textos produzidos ao longo da intervenção, podemos notar que os alunos se mostraram interessados no tema e buscaram ampliar seu repertório quanto a ele. As atividades feitas não tiveram o objetivo de simplesmente cumprir a obrigação de aluno, visto que todos eram voluntários, mas sim de conhecer mais sobre o assunto, de observar como a comunidade escolar vê e se comporta perante a inclusão dos deficientes. Vimos isso nas perguntas elaboradas por eles, na escolha dos entrevistados e das perguntas direcionadas a cada um e nas retextualizações produzidas, utilizando diversos textos, informações, dados e não deixando com que a temática principal 
fosse colocada como periférica. Os diferentes recortes escolhidos pelos alunos em suas produções mostram como a inclusão precisa ser amplamente discutida e demonstrou como eles se tornaram sensíveis a um tema que ainda é tão burocrático nos espaços escolares.

Creio que, além de todos os ganhos relacionados ao processo de aprendizado dos gêneros entrevista e reportagem, da retextualização e do uso do discurso citado, a sensibilização e conscientização dos alunos quanto à importância da inclusão dos alunos deficientes foi um grande passo para o desenvolvimento da cidadania e da criticidade dos alunos participantes, inserindo-os "na missão de incluir todas as pessoas e garantir uma educação baseada na convivência e respeito à diversidade" (VALLE, 2016, p.17). 


\section{CONSIDERAÇÕES FINAIS}

Pode-se afirmar que o professor, quando se torna pesquisador de sua própria prática e do contexto no qual está inserido, assim como seus alunos, é capaz de transformar o processo de ensino-aprendizagem através de práticas reflexivas. No atual cenário da educação básica, é fundamental que os professores busquem formas de atrelar teoria e prática ao planejarem suas aulas, visando sempre ao desenvolvimento da aprendizagem dos alunos.

Como já apresentado neste texto, consideramos que o processo de retextualização entre os gêneros entrevista e reportagem é relevante nas práticas sociais, visto que tal ato é muito frequente no nosso cotidiano (tanto entre modalidades, quanto entre gêneros), mesmo que, muitas vezes, não nos damos conta da complexidade de tal realização. Também é fundamental que haja, por parte dos estudantes, a compreensão da importância do discurso citado em gêneros jornalísticos, bem como da transposição entre discursos para a produção do gênero reportagem, visando à fidedignidade do que é retextualizado ao produzirmos um novo texto.

A pesquisa ação apresentada neste texto ocorreu em turma de $8^{\circ}$ ano do Ensino Fundamental, composta de 33 alunos e foi motivada pelo contexto da escola e sala de aula bem como por análises qualitativas feitas nas primeiras aulas do ano letivo de 2020. Nessa análise, notou-se que os alunos apresentaram dificuldades na compreensão não só do comando para uma chamada de produção, como também da realização do processo de retextualização, visto que tal processo, embora seja natural, não é mecânico. Ademais, a transposição do discurso no processo de produção de texto escrito mostrou-se como uma questão que demandava investimento em nossas aulas, a fim de que houvesse reconhecimento das estratégias de uso e de passagem de um discurso a outro, evitando prejuízo das informações dadas no novo texto. Tendo isso em vista, optamos pela escolha dos gêneros do campo jornalístico/midiático entrevista e reportagem, uma vez que o uso do discurso citado é proeminente em suas construções. Por fim, apesar de não encontrar problemas na socialização dos alunos no ambiente escolar, vi a necessidade de valorizar a educação inclusiva não só como uma ferramenta de socialização, mas também uma forma de contribuir para o desenvolvimento dos alunos com deficiência e promover a reflexão dos alunos participantes da pesquisa sobre o seu papel em relação aos colegas, visto que a forma como tais alunos são acolhidos no ambiente escolar reflete diretamente no seu processo de aprendizagem.

Sob a hipótese de que um trabalho contextualizado do discurso citado em gêneros em que eles se fazem relevantes seria crucial para a compreensão não apenas da forma desse discurso, mas de sua intencionalidade e de seus efeitos de sentido no texto, e de que um trabalho 
com a temática dos alunos especiais ajudaria na sensibilização e conscientização em relação à inclusão de alunos com deficiência no espaço escolar e a sua contribuição para o processo de aprendizagem desses alunos, acreditamos que um trabalho reflexivo poderia auxiliar no desenvolvimento acadêmico dos participantes da pesquisa, principalmente, no que se refere aos conteúdos gramaticais relacionados ao uso do discurso citado, estimulando os alunos no reconhecimento dos aspectos relacionados a essa ação, bem como na construção dos gêneros textuais entrevista e reportagem.

Nesse contexto, esta pesquisa ação assumiu o objetivo de proporcionar um ensino de língua por práticas mais coerentes com o cenário e público-alvo pesquisado e, através de práticas reflexivas, ampliar o conhecimento dos alunos quanto aos gêneros textuais entrevista e reportagem, enfocando os processos de retextualização envolvidos na produção de uma reportagem que parta de uma entrevista e de outros textos-base e ressaltando a relevância de características essenciais à adequada transposição de discursos, contribuindo para a formação de estudantes mais conscientes sobre o uso e funcionamento da língua. Junto a isso, objetivouse levar os alunos à reflexão do seu papel como agentes transformadores no contexto escolar no que tange à inclusão de alunos com deficiência em seus grupos de estudo e de trabalho.

Para alcançar tais objetivos, uma intervenção em sala de aula foi proposta e delineada por meio de uma sequência de atividades que envolveram as práticas de leitura, escrita, oralidade e análise linguística. A fim de observar quais fatores deveriam ser foco da intervenção, tal qual prevê o modelo da sequência didática, um diagnóstico da turma foi feito por meio da análise da produção de textos elaborados pelos alunos, por meio dos quais eles retextualizaram o gênero entrevista, transformando-o em uma reportagem.

A análise da produção inicial revelou que, embora muitos reconhecessem aspectos estruturais do gênero textual reportagem, muitos alunos não conheciam muitas das estruturas essenciais que colaboram para a construção do referido gênero textual, mantendo, muitas das vezes, sua produção no mesmo formato do texto-base utilizado, a entrevista. Devido a isso, muitos alunos não faziam uso adequado dos estilos direto e indireto do discurso citado na construção de seus textos, repetindo a estrutura canônica da entrevista de pergunta/resposta.

Essa análise suscitou a elaboração de atividades que explorassem o estudo da estrutura e das características prototípicas dos gêneros textuais entrevista e reportagem, além de priorizar o conhecimento do uso e das características prototípicas dos discursos direto e indireto. As atividades elaboradas para a sequência didática, além de proporcionarem reflexões acerca de algumas das operações do processo de retextualização, propostas por Marcuschi (2001), 
proporcionaram também uma frequente reflexão sobre a inclusão de pessoas com deficiência, especialmente no espaço escolar.

Infelizmente, após o diagnóstico, houve uma demora significativa na retomada da intervenção, visto que, por conta da pandemia da Covid-19, as aulas, no formato presencial, foram suspensas em 18 de março de 2020 no estado de Minas Gerais e continuam suspensas até a data de defesa deste trabalho. No dia 18 de maio de 2020, as aulas foram retomadas, porém remotamente, e as etapas previamente pensadas foram reelaboradas para serem aplicadas nesse contexto, numa tentativa de manter sua aplicação, apesar do caótico contexto escolar em tempos de pandemia.

A intervenção foi composta por 6 etapas, em um total de 94 aulas, sendo apenas a primeira delas aplicada de forma presencial. As etapas seguintes, incluindo a produção final, foram aplicadas de forma remota, com aulas online através da plataforma Zoom e com a participação de 5 alunos voluntários, tal qual explicitado neste texto.

Sem dúvida, o cenário educacional com a suspensão das aulas presenciais devido à pandemia do coronavírus não foi aquele julgado por mim como ideal para a aplicação da intervenção, mas, por forte motivação pessoal, a concretização da pesquisa se fez necessária e desafiadora, inclusive nesse contexto. Ter um resultado, independentemente do público alcançado, parecia ser mais real do que apenas uma proposta, pensando nessa tão distante sala de aula ideal.

As atividades aplicadas em todas as etapas foram constantemente elaboradas tendo em vista as motivações da pesquisa, os dados advindos de questionário e da análise diagnóstica e os progressos e/ou dificuldades apresentados pelos alunos aula a aula. A análise do questionário aplicado aos alunos mostrou que, nem sempre, eles se dão conta da presença de alunos com deficiência dentro de sala de aula. Ademais, poucos relataram conviver com pessoas portadoras de alguma necessidade especial. Apesar disso, os alunos não enxergam a inclusão de alunos com deficiência como um problema, mas destacam que, muitas vezes, esses alunos são esquecidos e ignorados pelos professores, não havendo um atendimento especializado e/ou individualizado. Além disso, mesmo reconhecendo casos de prática de bullying por parte de alguns colegas, apontaram benefícios para a inclusão de alunos deficientes, julgando ser uma ação importante e de direito desses alunos.

A análise das produções finais revelou que muitos foram os ganhos ao longo das etapas da intervenção, culminando no resultado da produção final. Durante as atividades, os alunos puderam refletir e construir conhecimentos e conceitos acerca da produção do gênero reportagem, o que foi prontamente atendido pelos alunos ao utilizarem as estruturas 
proeminentes na construção do gênero, além de estruturas opcionais que contribuem fortemente para seu propósito comunicativo. Observamos que, apesar de formatos diferenciados, as reportagens produzidas na última etapa - produção final - atenderam ao que foi proposto na chamada de produção, mostrando que aspectos como manchete, subtítulo/linha fina e lide foram consolidados por todos os alunos, enquanto que as estruturas opcionais como imagens e links, bem como seu aspecto multimodal, ainda são aspectos que precisam ser mais explorados. Em relação ao uso do discurso citado, percebemos que os ganhos também foram notáveis, uma vez que todas as produções apresentaram a presença de ao menos um dos estilos do discurso, com a consolidação de suas características tradicionais, além do uso desses estilos de forma mesclada, revelando a confluência entre os estilos.

No que se refere ao processo de retextualização, cabe ressaltar que não houve ênfase na exploração das operações de idealização, reformulação e compreensão do processo de retextualização em uma etapa específica, visto que foram, durante quase todas as etapas da intervenção, analisadas e refletidas conjuntamente com outros aspectos. Como destacado anteriormente, a análise das produções finais revelou que, no que diz respeito à retextualização, os alunos mostraram ter avançado em alguns aspectos textuais envolvidos na retextualização. Ressaltamos que 3 destes aspectos apresentaram ganhos: idealização, aspecto amplamente desenvolvido, através das operações 1 e 3 que tratam da eliminação de marcas de interação, hesitações, repetições e redundâncias; reformulação, aspecto parcialmente desenvolvido, através das operações 2 e 4 que tratam da inserção de paragrafação e pontuação; e, compreensão, aspecto amplamente desenvolvido, que é diluído em todas as operações de retextualização.

A análise da produção final revelou, ainda, que uso da pontuação, presente nas operações 2 e 4, é um aspecto problemático na produção final de todos os alunos, o que mostra que tal dificuldade demonstrada pelos alunos ainda precisa ser amplamente refletida e consolidada.

Além dos aspectos relacionados aos gêneros textuais e à análise linguística, reforço a relevância da temática da pesquisa para a sensibilização e a conscientização acerca da socialização e do acolhimento dos alunos com deficiência no ambiente escolar. As etapas da intervenção mostraram que os estudantes estavam motivados a discutir o assunto e em pensar estratégias para auxiliar na promoção dos alunos com deficiência, dentre as ideias dadas durante nossas aulas estão atividades diferenciadas de acordo com a necessidade de cada aluno, jogos e dinâmicas. Ademais, quando indagados sobre a forma que poderiam contribuir, os alunos disseram que é fundamental que os alunos com deficiência nunca estejam sozinhos, "podemos 
sentar junto com eles durante as aulas e ajudar eles nas atividades que o professor pedir", disse o aluno 2 em um dos momentos. Além disso, a produção final dos alunos deixou claro que eles incorporam diversificados novos conhecimentos sobre o assunto, mobilizaram-se para entrevistar (e também guiar à reflexão) pessoas relevantes para esse processo de mudança de maior inserção dos alunos especiais, o qual precisa ser discutido e implementado.

Vale ressaltar que, no momento da qualificação, não fazia ideia de qual rumo minha pesquisa tomaria, não tinha noção de como prosseguir, além de uma intervenção propositiva. Porém, o incentivo da Profa. Dra. Natália fez com que minha vontade fosse mantida e que a intervenção proposta fosse aplicada, mesmo com todas as dificuldades e obstáculos enfrentados. O receio em ter meu projeto frustrado pela ausência de alunos tornou-se esperança e força com a grata surpresa dos meus 5 alunos voluntários. Alunos que eram de fato meus pela primeira vez na escola em que trabalho, alunos que se mostraram empenhados em aprender e em me ajudar a realizar esse sonho que um dia já foi tão distante.

Os frutos dessa pesquisa transbordam meu coração de alegria e de esperança: vislumbro uma educação melhor e de qualidade, graças ao empenho de tantos profissionais que não deixam de lutar para que a educação tenha futuro, sabendo que está em nossas mãos fazer a diferença. Ademais, os resultados me motivam a continuar a pesquisa, aprofundando-me em aspectos relevantes para o uso e a função do discurso citado na construção do gênero textual reportagem, como a pontuação e coesão sequencial. Também a intervenção me incentivou a refletir e a agir ainda mais sobre como as aulas devem se transformar para serem facilitadoras no processo de ensino-aprendizagem dos alunos portadores de necessidades especiais. Devemos pensar em meios e instrumentos para que a inclusão não seja apenas social, mas também de desenvolvimento acadêmico desses alunos.

Ser aluna do Mestrado Profissional em Letras, sem dúvida, foi a realização de um sonho e um divisor de águas na minha vida profissional, principalmente, cursando na unidade em que me graduei. Entretanto, apesar de estar vencendo essa etapa da minha vida acadêmica, tornando-me de fato uma pesquisadora, muitas são as angústias que sinto quanto ao futuro da educação. Alcançar resultados satisfatórios para a pesquisa, ver os alunos motivados a participar, promover mudança no contexto em que me encontro são algumas das certezas que me movem depois dessa enriquecedora experiência de ser mestranda no Mestrado Profissional em Letras. Além disso, o momento de pandemia em que ainda estamos vivendo é um dificultador do processo de aprendizagem, visto que a maioria dos alunos da rede pública de ensino não têm acesso às ferramentas necessárias para o ensino remoto. Tudo isso gera angústias de como estarão nossos alunos quando tudo isso passar. 
Resta a certeza de que, independente do futuro, o Profletras mudou para sempre minha postura como educadora e, também, como pesquisadora. 


\section{REFERÊNCIAS}

ANTUNES, Irandé. Aula de português: encontro \& interação. São Paulo: Parábola Editorial, 2003.

ANTUNES, Irandé. Gramática contextualizada: limpando 'o pó das ideias simples'. São Paulo: Parábola Editorial, 2014.

ARANHA, M. S. F. Educação Social e Municipalização. In: MANZINI, E. J. (Org.). Educação Especial: temas atuais. Marília: Ed. da Unesp, 2000, p. 1-9.

AUTHIER-REVUZ, J. Heterogeneidade(s) enunciativa(s). Caderno de Estudos Linguísticos, v.19, 1990, p. 25-42.

BAGNO, M. Gramática, para que te quero? Os conhecimentos linguísticos nos livros didáticos de português. São Paulo: Aymará, 2010.

BAKTHIN, M (VOLOCHÍNOV). Marxismo e filosofia da linguagem. 5ed. São Paulo: Hucitec, 1990.

BALTAR, Marcos. Competência discursiva e gêneros textuais: uma experiência com o jornal de sala de aula. Caxias do Sul, RS: Educs, 2004.

BENITES, S. A. L. Contando e fazendo história: a citação no discurso jornalístico. São Paulo: Artes\&Ciência, 2002.

BENFICA, M. F. B. Atividades de retextualização em livros didáticos de português: estudo dos aspectos linguístico-discursivos dos gêneros implicados. Tese (Doutorado) - FALE, Universidade Federal de Minas Gerais - Belo Horizonte, 2013.

BONINI, Aldair. Os gêneros do jornal: questões de pesquisa e ensino. In: KARWOSKI, Acir Mário; GAYDECZKA, Beatriz; BRITO, Karim Siebeneicher. Gêneros Textuais: reflexões e ensino. 4 ed. São Paulo: Parábola Editorial, 2011, p. 53-68.

BORTONI-RICARDO, S. M. O professor pesquisador. São Paulo: Parábola Editorial, 2008.

BRASIL. Base Nacional Comum Curricular: Educação Infantil e Ensino Fundamental. Brasília: MEC/Secretaria de Educação Básica, 2017.

BUNZEN, Clécio.; NASCIMENTO, Gláucia. Gramática na sala de aula: algumas reflexões sobre o ensino dos substantivos. REVISTA LETRAS (UFSM/ON-LINE), 2019, p. 249-276.

CASTRO, G. Formas sintáticas de enunciação: o problema do discurso citado no Círculo de Bakthin. In: BRAIT, B. (Org.). Bakthin e o círculo. São Paulo: Contexto, 2009.

CAVAlCANTE, Mônica Magalhães. Os sentidos do texto. São Paulo: Contexto, 2012.

CUNHA, Celso; Cintra, Luís F. Lindley. Nova Gramática do português contemporâneo. 3ed. Rio de Janeiro: Nova Fronteira, 2001. 
COSTA-HÜBES, T.C.; SIMIONI, C.A. Sequência didática: uma proposta metodológica curricular de trabalho com os gêneros discursivos/textuais. In: BARROS, E. M. D.; RIOSREGISTRO, E. S. (Org.). Experiências com sequências didáticas de gêneros textuais. Campinas: Pontes Editores, 2014, p. 15-39.

D'ANDREA, C. F. B.; RIBEIRO, A. E. Retextualizar e reescrever, editar e revisar: Reflexões sobre a produção de textos e as redes de produção editorial. REVISTA VEREDAS (UFJF/ON-LINE), 2010, p. 64-74.

DELL'ISOLA, R. L. P. Retextualização de gêneros escritos. Rio de Janeiro: Lucerna, 2007.

DIONISIO, A. P. Gêneros multimodais e multiletramento. In: KARWOSKI, B.G. \& BRITO, K. S. (Org). Gêneros textuais: reflexões e ensino. 3ed. Rio de Janeiro: Nova Fronteira, 2011, p.138-152.

ENGEL, G. I. Pesquisa-ação. EDUCAR (Editora da UFPR), 2000, p.181-191.

FRANCHI, C. Mas o que é mesmo "gramática"? In: POSSENTI, Sírio (org.) Mas o que é mesmo "gramática"?. São Paulo: Parábola Editorial, 2006. p. 11-99

GARCIA, Letícia Afonso Rosa. O discurso citado nas reportagens telejornalísticas: uma análise a partir do Jornal Nacional. Revista Travessias, v. 3, n. 1. Paraná, 2009, p. 1-19.

GERALDI, J. W. O texto na sala de aula. São Paulo: Anglo, 2012[1984].

HOFFNAGEL, J. C. Entrevista: uma conversa controlada. In: DIONÍSIO, A. P; MACHADO, A. R.; BEZERRA, M. A (Org.). Gêneros textuais e ensino. São Paulo: Parábola Editorial, 2010, p. 195-208.

KOCH, I. V.; ELIAS, V. M. Ler e escrever: estratégias de produção textual. São Paulo: Contexto, 2018.

KRESS, Gunther; VAN LEEUWEN, Theo. Reading Images: the gramar of visual design. New York: Routledge, 1996.

KRESS, Gunther. Literacyin the New Media Age. London: Routledge, 2003.

KRESS, Gunther. Multimodality: a social semiotic approach to contemporary communication. London: Routledge, 2010.

LIMA, Rocha. Gramática normativa da língua portuguesa. 49.ed. Rio de Janeiro: José Olympio, 2011.

MAGALHÃES, T. G. e CRISTOVÃO, V. L. L. Sequências e projetos didáticos no pacto nacional pela alfabetização na idade certa: uma leitura. Campinas/SP: Pontes Editores, 2018.

MANTOAN, Maria Teresa Eglér. Inclusão Escolar: O que é? Por quê? Como fazer?. São Paulo: Summus, 2015. 
MARCUSCHI, Luiz Antônio. Da fala para a escrita: atividades de retextualização.10ed. São Paulo: Cortez, 2001.

MARCUSCHI, Luiz Antônio. Produção textual, análise de gêneros e compreensão.3 ed. São Paulo: Parábola Editorial, 2008.

MARCUSCHI, Luiz Antônio. Gêneros textuais: configuração, dinamicidade e criculação. In: KARWOSKI, Acir Mário; GAYDECZKA, Beatriz; BRITO, Karim Siebeneicher. Gêneros Textuais: reflexões e ensino. 4 ed. São Paulo: Parábola Editorial, 2011, p. 17-32.

MATENCIO, M. L. M. Atividades de retextualização em práticas acadêmicas: um estudo do gênero resumo. Scripta, v. 6, n. 11, p. 25-32, 2002.

MENDONÇA, Marcia. "Análise linguística no ensino médio: um novo olhar.” In: BUNZEN, C. e MENDONÇA, M. (Orgs.). Português no ensino médio e formação do professor. São Paulo: Parábola Editorial, 2006.

MIRANDA, N. S. Reflexão metalinguística do ensino fundamental: caderno do professor. Belo Horizonte: Ceale/FaE/UFMG, 2006.

MOREIRA, Juliana Maria de Oliveira et al. Gêneros pautando um ensino reflexivo do adjetivo e do advérbio: discussões sobre bullying e cinema em um novo contexto escolar. Dissertação (Dissertação em Letras) - Universidade Federal de Juiz de Fora, Juiz de Fora, 2019.

PAULIUKONIS, Maria Aparecida. Texto e contexto. In: VIEIRA, S. R.; BRANDÃO, S. F. (Org.). Ensino de gramática: descrição e uso. 2. ed. São Paulo: Contexto, 2007, p.239-258.

PINTON, F. M.; STEINHORST, C.; BARRETO, T. V. (Org.). Glossário de gêneros e suportes textuais [recurso eletrônico]: Base Nacional Comum Curricular. Santa Maria, RS: UFSM, CAL, NEPELIN, 2020.

RIBEIRO, A. E. Textos multimodais: leitura e produção. 1ed. São Paulo: Parábola Editorial, 2016.

ROJO, Roxane. As relações entre fala e escrita: mitos e perspectivas - Caderno do professor. Belo Horizonte: Ceale, 2006.

ROJO, Roxane. Textos multimodais. In: Glossário Ceale: termos de alfabetização, leitura e escrita para educadores / Isabel Cristina Alves da Silva Frade, Maria da Graça Costa Val, Maria das Graças de Castro Bregunci (orgs). Belo Horizonte: UFMG/Faculdade de Educação, 2014. Disponível em: http://www.ceale.fae.ufmg.br/app/webroot/glossarioceale/verbetes/textos-multimodais Acesso em março de 2021.

SANTOS, Edimar Adalberto dos; MOURA, Kátia Maria de. A relação professor e aluno e sua influência no processo de inclusão escolar. In: EVÊNCIO, Kátia Maria de Moura (Org.). Educação inclusiva: diversos olhares entre teorias e práticas. 1ed. Curitiba: Appris, 2018, p.2552. 
SCHNEUWLY, B.; DOLZ, J. (Org.). Gêneros orais e escritos na escola. Campinas: Mercado de Letras, 2004.

SIGILIANO, Natália Sathler; SILVA, Wagner Rodrigues. Diagnóstico de propostas de análise linguística em livros didáticos aprovados em programa oficial. In: MAGALHÂES, Tânia Guedess; GARCIA-REIS, Andreia Rezende; FERREIRA, Helena Maria (orgs.). Concepção discursiva da linguagem: ensino e formação docente. Campinas: Pontes Editores, 2017.

SIGILIANO, Natália Sathler. Análise Linguística em livros didáticos: uma prática em transformação, um caminho possível, 2020 (no prelo).

SILVA, Aline Maira. Educação especial e inclusão escolar: história e fundamentos. Curitiba: Editora Intersaberes, 2012.

SILVA, José Ronaldo Ribeiro da; BARBOSA, Maria do Socorro Maia Fernandes. O lugar da categoria discurso citado na abordagem dialógica da linguagem. Linguasagem, São Carlos, v. 25 (1), 2016.

SILVA, Thiago Santos. O gênero discursivo reportagem de revista: um estudo de suas características e análise de exemplares da revista Istoé. REVISTA SOLETRAS (UERJ/ONLINE), 2012, p.191-206.

SOUZA, Abda Alves; SOUZA, Sirlene Barbosa. A análise linguística e sua relação com a produção textual. In: SILVA, Alexsandro; PESSOA, Ana Cláudia; LIMA, Ana (orgs.) Ensino de gramática: reflexões sobre a língua portuguesa na escola. Belo Horizonte: Autêntica Editora, 2012, p. 47-66.

SUASSUNA, L. Ensino de análise linguística: situando a discussão. In: SILVA, Alexsandro; PESSOA, Ana Cláudia; LIMA, Ana (Org.). Ensino de gramática: reflexões sobre a língua portuguesa na escola. Belo Horizonte: Autêntica Editora, 2012, p. 11-28.

THIOLLENT, M. Metodologia da pesquisa-ação. 18.ed. São Paulo: Cortez, 2011.

TOLEDO, R. F.; JACOBI, P. R.. Pesquisa-ação e educação: compartilhando princípios na construção de conhecimentos e no fortalecimento comunitário para o enfrentamento de problemas. Educ. Soc., Campinas, v. 34, n. 122, jan-mar. 2013, p. 155-173.

TRAVAGLIA, Luiz Carlos. Gramática e Interação: uma proposta para o ensino de gramática. São Paulo: Cortez, 2009.

VALLE, A. S. V. A reinvenção do cotidiano escolar: percepções de docentes de turmas regulares sobre a inclusão. In: RODRIGUES, I. E. (Org.). Educação Inclusiva: um desafio para o século XXI. Jundiaí: Paco Editorial, 2016, p. 15-32.

VIEIRA, Sílvia Rodrigues. Prática de análise linguística sem ensino de gramática? Reflexões e propostas. In: ATAÍDE, C. A. de et alii (org.). Gelne 40 anos. Vivências teóricas e práticas nas pesquisas em Linguística e Literatura. São Paulo: Blucher, 2017, p. 299-318.

WACHOWICZ, Teresa Cristina. Análise linguística nos gêneros textuais. São Paulo: Editora Saraiva, 2012. 


\section{ANEXO A - Roteiro de perguntas para entrevista}

\section{Produção Textual Módulo 3 - Etapa 3}

Você já leu, viu e ouviu bastante sobre a Inclusão das pessoas portadoras de necessidades especiais em diferentes contextos, principalmente no espaço escolar. Junto com sua professora, pense na realidade dessas pessoas na sua cidade e na sua escola e formule possíveis perguntas para uma entrevista com pessoas ligadas à comunidade escolar sobre o acolhimento dos alunos portadores de necessidades especiais, sobre os recursos disponibilizados para esses alunos e, principalmente, sobre o que ainda precisa ser feito para integrá-los à escola e à comunidade escolar.

Roteiro para entrevista - Perguntas

1- $\mathrm{Na}$ sua opinião, quais seriam os recursos necessários que todas as escolas deveriam disponibilizar para atender aos alunos com deficiência?

2- No seu ponto de vista, como os alunos com deficiência são tratados?

3- Você acha que a nossa escola tem recursos suficientes para atender aos alunos com deficiência? (Explique)

4- O que fazer quando o aluno com deficiência sofre bullying?

5- Em sua opinião, você acha que os alunos com deficiência são incluídos nas atividades da escola?

6- O que a escola pode oferecer para os alunos com deficiência?

7- Na sua experiência profissional, o que você tem observado hoje sobre a realidade da inclusão escolar?

8- De que maneira os alunos com deficiência podem ser atendidos durante o ensino remoto?

9- Como os alunos com deficiência devem ser avaliados em suas atividades escolares?

10- O que fazer quando o aluno com deficiência tem um comportamento agressivo?

11- Em sua opinião, quais são as principais dificuldades da escola no processo de inclusão dos alunos com deficiência?

12- Qual o seu papel no processo de inclusão dos alunos com deficiência? 


\section{ANEXO B - Entrevista escrita (aluno 1)}

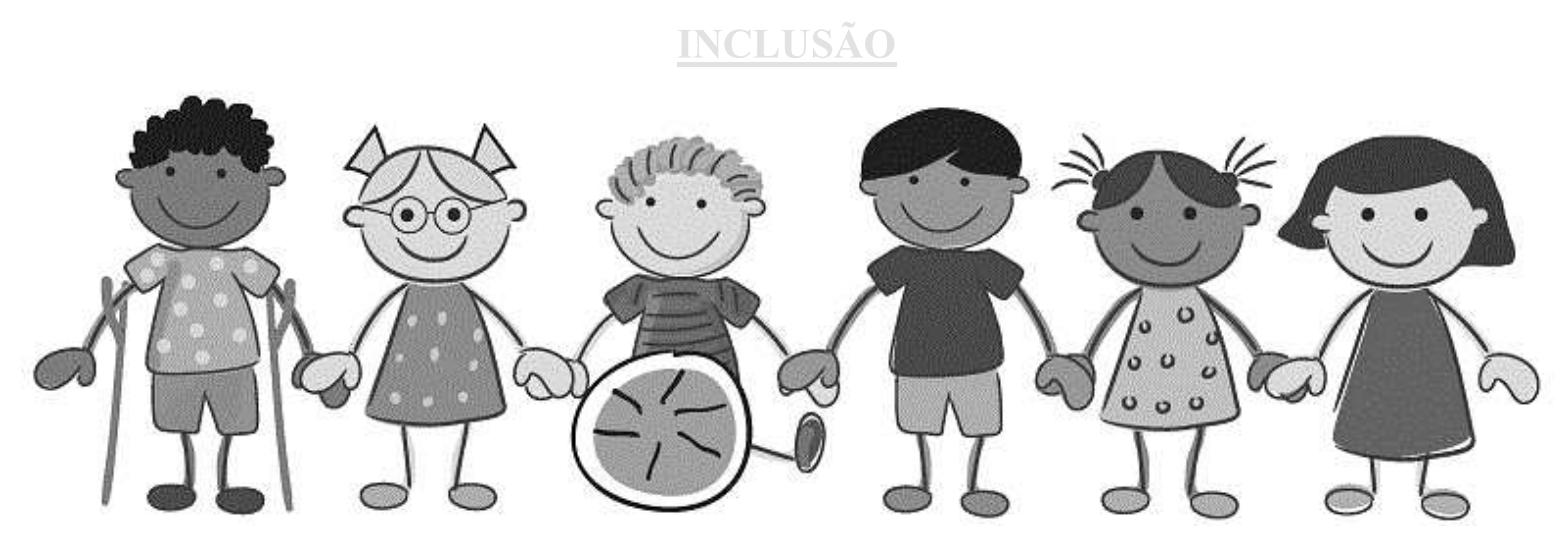

Marcia Da Costa Corrêa é bibliotecária na escola estadual Engenheiro Henrique Dumont é casada possui um filho e dois netos, trabalha a 15 anos na área da educação e é dedicada em seu trabalho e como mãe, Márcia mora em minas gerais santos dumont tem 55 anos.

Hoje teremos uma entrevista com Márcia da Costa Corrêa que dará um pouco de sua opinião sobre o assunto inclusão nas escolas brasileiras.

- Em sua opinião, quais seriam os recursos necessários que todas as escolas deveriam disponibilizar para atender aos alunos com deficiência?

Eu penso que o mais importante é a escola ter acessibilidade ,também assim um outro recurso necessário é a sala de recurso com o material bastante diversificado que possa a atender as necessidades dos alunos, também eu penso que no preparo do grupo docente para estar recebendo esses alunos e trabalhando com eles uma adaptação do projeto político pedagógico o uso da tecnologia e também penso que uma parceria entre escola e a família , basicamente muitos recursos.

- Em sua opinião, você acha que os alunos com deficiência são incluídos nas atividades da escola?

Na minha opinião, que eu pude perceber apesar de não ter tanto contato devido a pandemia os alunos sempre são incluídos e participam de todas as atividades propostas na escola. 
- Você acha que a nossa escola tem recursos suficientes para atender aos alunos com deficiência? (Explique)

Eu penso que a escola possui recurso sim, de acordo com a demanda de alunos com deficiência que ela recebe.

- O'Que fazer quando o aluno com deficiência sofre bullying?

Quando um aluno com deficiência sofre bullying, eu penso que a professora deve conversar sobre a deficiência desse aluno com todos os outros da turma na presença dele e também chamar os pais ou responsáveis para falar sobre o bullying e sobre a inclusão. 


\section{ANEXO C - Entrevista escrita (aluno 2) \\ Inclusão das pessoas portadoras de necessidades especiais Entrevista com a Teacher Ana Caroline}

Ana Caroline de Meireles Silva, ou como muitos a conhecem, Carol, tem vinte e oito anos, e atua como professora de língua inglesa a aproximadamente nove anos. Ela começou sua carreira dando aulas em cursos de extensão na faculdade que se formou, a UFOP, Universidade Federal de Ouro Preto. Após diplomar-se começou a dar aulas em cursinhos livres. Em 2015 ingressou no Estado como contratada, e agora já está como efetiva em dois cargos. Além de dar aula em escolas públicas, Teacher Carol, no momento, também é professora de inglês dando aulas particulares.

- Na sua experiência profissional, o que você tem observado hoje sobre a realidade da inclusão escolar?

Bom, esse é um tema que realmente deveria ter mais espaço pra discussão, mas na prática eu acredito que aconteça o seguinte: em nossa escola (Escola Estadual Engenheiro Henrique Dumont - Polivalente) temos muitos alunos que são de inclusão, porém, acredito que muitas vezes, essa palavra, "INCLUSÃO" não é trazida para a realidade de fato, visto que muitas vezes nós professores temos dificuldade em trabalhar com esses alunos em relação as limitações de cada um, não temos a preparação certa para lidar com os mesmos. Já os outros alunos, acredito que acolhem bem os alunos de inclusão, acho que isso acontece de forma bem bacana e legal, mas algumas vezes os próprios alunos portadores de necessidades especiais, se retraem um pouco e não deixam os outros se aproximarem. Acho que essa é a realidade na nossa escola.

- Você acha que a nossa escola tem recursos suficientes para atender aos alunos com deficiência? 
Em relação ao espaço físico eu acredito que sim, mas no que se refere em outros materiais e recursos, algumas vezes eu sinto falta, por exemplo de uma mesa para um aluno cadeirante... Hoje em dia nos temos mais de um aluno cadeirante, e apenas uma mesa para que um aluno utilize. Enfim, entre outros recursos que ainda faltam. Mas na maioria das vezes acho que atende sim.

\section{- Em sua opinião, quais são as principais dificuldades da escola no processo de inclusão dos alunos com deficiência?}

O número de alunos que nós temos dentro de cada turma, que é muito grande, mas acredito que isso não seja responsabilidade da Escola em si, mas de uma organização do Estado como um todo. Uma sala tendo muitos alunos, dificulta o nosso trabalho para dar uma atenção maior aos alunos de inclusão, e também falta de preparação dos professores por não saber lidar com esses alunos de acordo com as suas limitações.

\section{- De que maneira você acha que os alunos com deficiência podem ser atendidos durante o ensino remoto?}

Essa é uma questão difícil, dado que nós estamos tendo uma certa dificuldade para atingir e contactar os alunos de um modo geral. Em nossa escola são as professoras de apoio, que estão entrando em contato com os alunos portadores de necessidades especiais, pois elas têm uma maior proximidade com eles. Geralmente elas passam as atividades para os responsáveis, que tentam fazer com os alunos. O ensino remoto fica muito limitado, as alternativas que nos temos é por ferramentas como o WhatsApp, vídeo chamadas, enfim, não vejo outras alternativas no momento! 


\section{ANEXO D - Reportagem (aluno 1)}

\section{Alunos com deficiências estão sendo cada vez mais incluídos nas escolas brasileiras}

Escolas com intuito de incluir todos os tipos de alunos nas atividades escolares tem aumentado ao longo dos anos em escolas públicas.

A cada dia que passa mais escolas começam a criar projetos de inclusão, onde a maioria deles sendo escolas públicas, estão cada vez mais presentes nessas escolas. A cada dia que passa o número de alunos com deficiência em escolas comuns tem se aumentado, em 2003 apenas 27\% dos alunos estudavam em salas comuns porém, este percentual foi crescendo até em 2014 onde já está em $79 \%$ de alunos com deficiência em salas comuns, um fato curioso é que $93 \%$ destes alunos estudam em escolas públicas onde os resultados estão cada vez melhores como Izabele que tem síndrome de down e está aprendendo a ler contar e escrever bem facilmente," eles são uma caixinha de surpresa, as vezes você pensa que não está fazendo nada por eles e te surpreendem" diz a professora Soraya sobre seus alunos. Algo que é muitos solicitados por mães destes alunos são os mediadores que ajudam os alunos durante as aulas a terem certos ganhos na escola " ele ta me mostrando que queria isso, que quer ir a rua, ir explorar, que quer ir ao mundo, eu o subestimava e não queria isso para ele pois sabia que teria dificuldades mas percebi que a escola realmente era importante para ele" diz Sheila Veloso mãe de Pedro (8) que é deficiente não fala e tem dificuldades para andar porém, com as idas a escola tem melhorado cada vez mais. Alguns alunos possuem relatos sobre escolas passados veja "algumas escolas particulares tinham uma vontade de serem inclusivas porém não possuíam uma infraestrutura para isso e não se propunham para ter, eram apenas promessas" " o Miguel não sabia ler, escrever, mal sabia escrever o nome todo ele veio pra cá há 2 anos hoje ele sabe ler, escrever redação, sabe o nome todo" diz Andrea Barboza Oliveira mãe de Miguel que é autista e estuda em escola pública. "Todo mundo tem condição de se desenvolver integralmente mais em medidas mais diferentes possíveis, sempre para que essas capacidades se ampliem" diz a educadora Maria Teresa Mantoan, que fala um pouco sobre sua opinião. As crianças estão felizes por terem esta oportunidade como Dandara que está festejando para conseguir uma escola com tanto afeto que ela precisa. 


\section{A Educação igual para todos}

Jornal Nacional apresenta uma reportagem especial sobre a educação inclusiva. A Educação inclusiva traz benefícios enormes para todos os alunos. Ao longo dos anos o número de alunos portadores de necessidades especiais em escolas comuns tem aumentado.

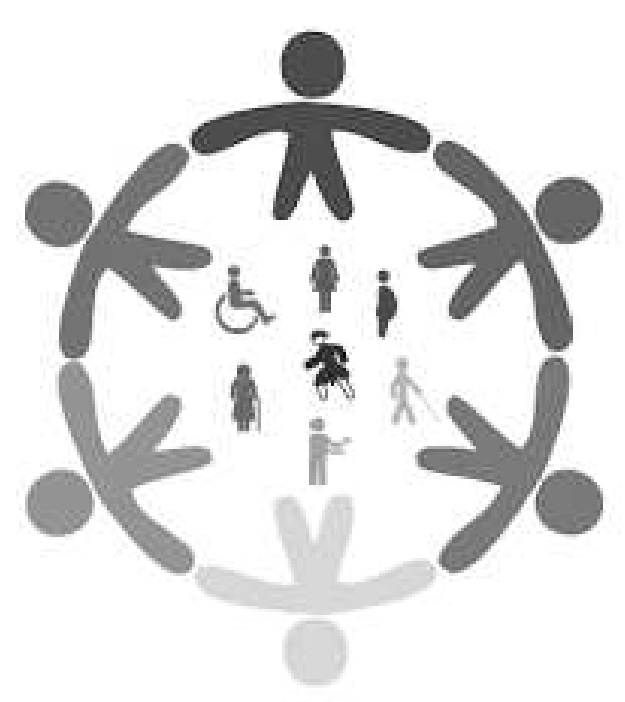

“Todo mundo é ímpar então precisamos nos adaptar a todo mundo, esse é o nosso mundo, a nossa sociedade" diz Antônio Carlos Souza, professor de Educação Física em uma escola inclusiva. Quase setecentas mil (700.000) crianças brasileiras portadoras de alguma deficiência estão hoje em escolas comuns, isso significa que todos os alunos estudam juntos, e com o mesmo currículo.

Visitando uma escola inclusiva uma das coisas que mais percebemos é o afeto que todos os alunos nos passam. O sorriso e a felicidade de todos a nos receber não têm preço. $\mathrm{O}$ afeto é uma disciplina de apoio para transformar a escola em um espaço para todos. Em um ambiente assim os adultos ensinam algumas coisas e aprendem outras que não estão nos livros.

A educação inclusiva começa em casa, a partir do momento que os pais se convencem que é preciso criar os filhos para a vida e não os manter isolados porque tem uma deficiência. A escola comum é um ponto de partida para a criança poder crescer como qualquer outra e ter a possibilidade de obter ganhos em sala de aula, e consequentemente em sua vida.

Pedrinho de oito (8) anos tem uma síndrome rara, não fala, anda com dificuldade, mas se interessa pelo que está ao seu redor. Seu comportamento melhorou depois que sua mãe com muita dificuldade, conseguiu o matricular em uma escola municipal na zona sul do Rio de Janeiro. 
"Ele está me mostrando isso, que quer ir pra rua, quer explorar, e conhecer o mundo. Ele é uma criança que eu subestimava, não queria isso pra ele, porque eu sabia que iriamos encontrar dificuldades, mas depois eu vi que a escola é importante pra ele", disse Sheila mãe de Pedrinho.

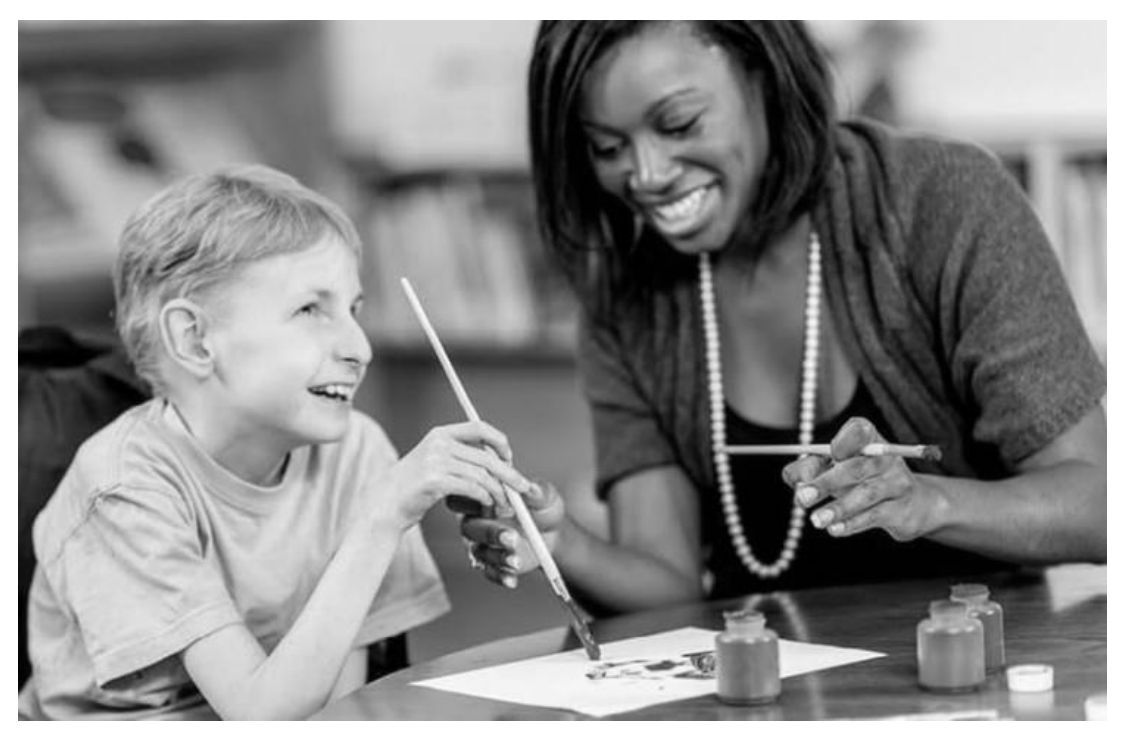

$\mathrm{Na}$ última década os números da inclusão se multiplicaram. Em 2003 somente 29\% estavam em escolas comuns, esse número subiu para $79 \%$ em 2014 , e a maioria desses alunos estudam em escolas públicas, por volta de $93 \%$.

E os casos de sucesso estão aparecendo, Izabele de 9 com síndrome de Down consegue reconhecer os números, fazer pequenas contas, escreve e lê palavras simples. A professora Soraya Sena (professora de Izabele), diz que que as crianças com deficiência são uma caixinha de surpresa, não sabemos até onde eles podem ir.

Mais um exemplo é de Andreia que assisti ao desabrochar do filho em uma escola municipal, Miguel de nove (9) anos é autista, tem dificuldades de se comunicar e de socializar. "Miguel já estudou em duas escolas particulares, elas tinham uma vontade de ser inclusivas, porém não tinham infraestrutura para isso e não se propunham a ter, eram só promessas. Miguel não conseguia ler, e mal sabia escrever o nome dele todo. Ele foi para a escola municipal tem dois anos, e hoje lê, escreve redações, sabe o nome dele todo, entre outras várias coisas", disse Andreia mãe de Miguel. 
Maria Teresa Eglés Mantoan, coordenadora do Laboratório de Estudos e Pesquisas em Ensino e Diferença (Leped), da Universidade Estadual de Campinas (Unicamp) diz que: "Todos têm a capacidade de se desenvolver integralmente, mas em medidas as mais diferentes possíveis, desafiar sempre que essa capacidade se amplie." 


\section{ANEXO F - Produção inicial (aluno 1)}

\section{Chamada de producão textual}

Agora é a sua vez de produzir uma reportagem!

Com a entrevista do criador do videogame em mãos, produza uma reportagem que trate do criador e da criação deste objeto tão requisitado por crianças, jovens e até por adultos. Utilize as informações dadas ao longo da entrevista, como por exemplo, a relação de Baer com a indústria do videogame. Essa reportagem, ao final do nosso projeto, poderá ser publicada na página da escola nas redes sociais, para que outros colegas, alunos, professores e toda a comunidade escolar possam conhecer mais sobre a criação do videogame.Capriche!

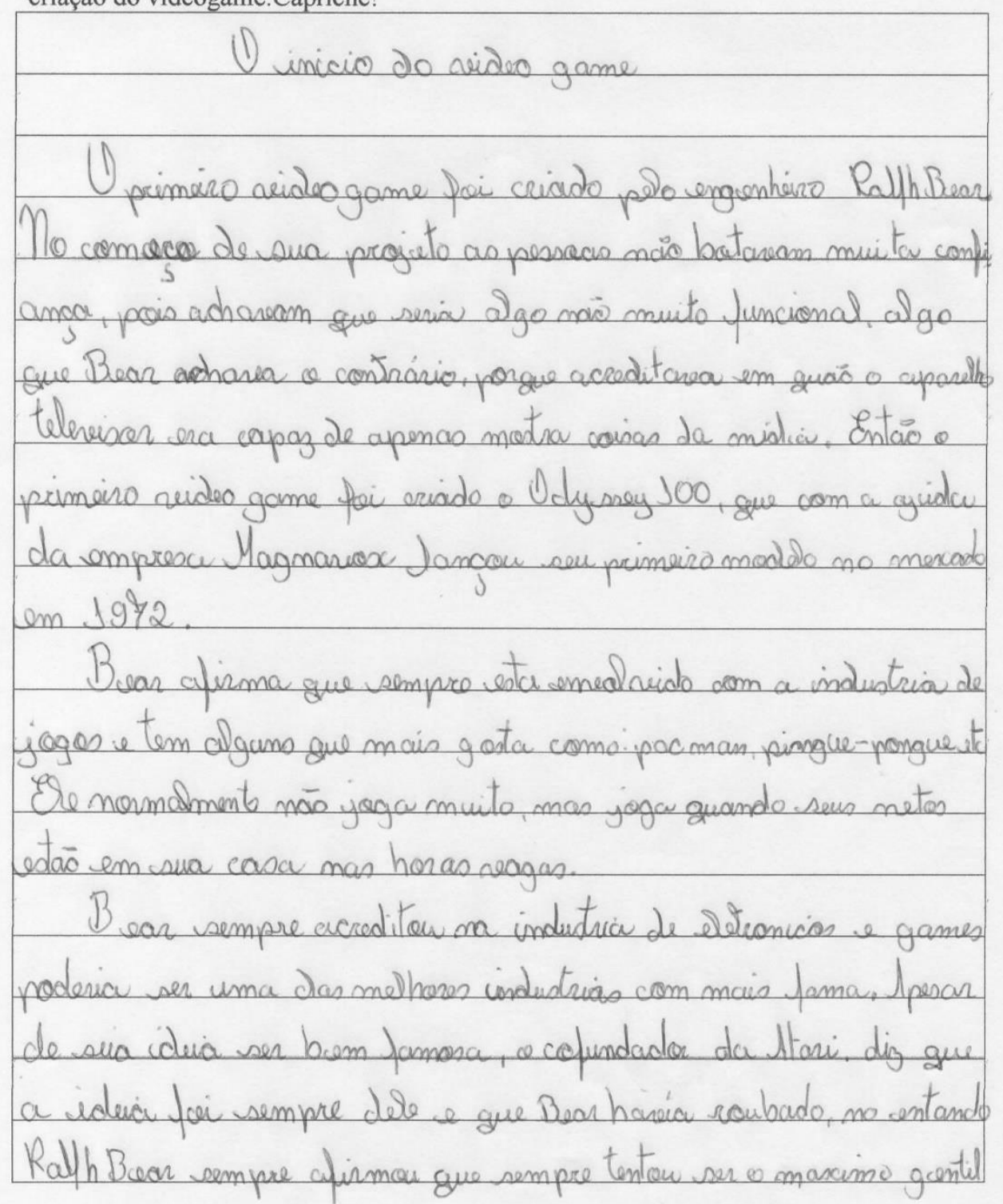


possired quando te se encontra com seu riveal. Ipesar de uma rida agitada Ralth Bear sempre afir mou gue seu suasso Heir sorte pois sua imencaia ha elgo que mä́ faria muito sentido. Mas Bear sempre afuimow gue sou suoseso por seu Obgessey 100 foi pila sua trabalho es esporco. Bear deu um utimo recado que ele disse a nos foi que a persoce gue guizer entrar no mer cado dos games é que seacé nä dered esperar ganhar muito dinkeiro on ficar famoso e sin fazorogne reacê foz de methor e ogue reacè gasta de fazer. 


\section{ANEXO G - Produção inicial (aluno 2)}

\section{Chamada de producão textual}

Agora é a sua vez de produzir uma reportagem!

Com a entrevista do criador do videogame em mãos, produza uma reportagem que trate do criador e da criação deste objeto tão requisitado por crianças, jovens e até por adultos. Utilize as informações dadas ao longo da entrevista, como por exemplo, a relação de Baer com a indústria do videogame. Essa reportagem, ao final do nosso projeto, poderá ser publicada na página da escola nas redes sociais, para que outros colegas, alunos, professores e toda a comunidade escolar possam conhecer mais sobre a criação do videogame.Capriche!

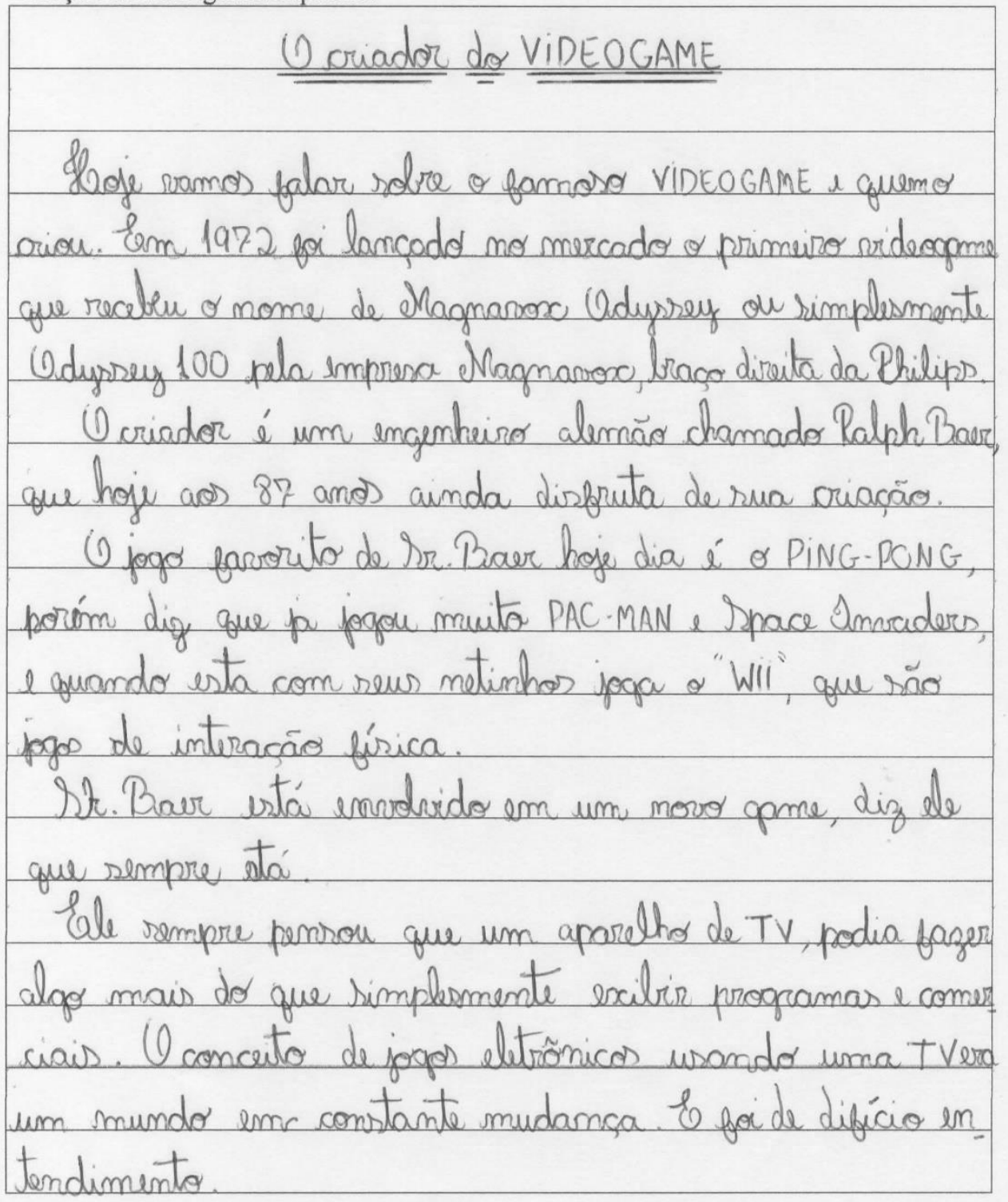


Na época o cofundador da eftari, Nolan Bushmell roubur a ideia de Baer, que sempre tentou rer a smais cordial e amigánel porsivel, mas numca recellu uma vospos ta de Bushmell entäo Bar esqueceu e procurou e associ ar com possoas que não timham esso tipo de preblema. 6 criador dig que tem um imengo orgulho de sua fanília, e éclaro que de suas realigacas profirsionais também, e o VIDECGAME é ro uma delas

Até 1977 foran vendidos e produgides mais de 350.000 apareltros, contudo ferz muito rucesso, a ideia que ninguím confiara gerou un imemsos lucro.

Único consellor que o engenheiro daria para qualquer pessoca em qualquer negócio é: "Não espere fazer um mi thã rápido. Zaca o que você fary melhor de melthor. Você rai rer foliz, e quem sabe até rico! 


\section{ANEXO H - Produção final (aluno1)}

\section{Nas escolas públicas como ocorre a educação inclusiva ?}

As escolas públicas em geral possuem uma sistema de aprendizagem bem mediano porém como a inclusáo ocorre nestas escolas

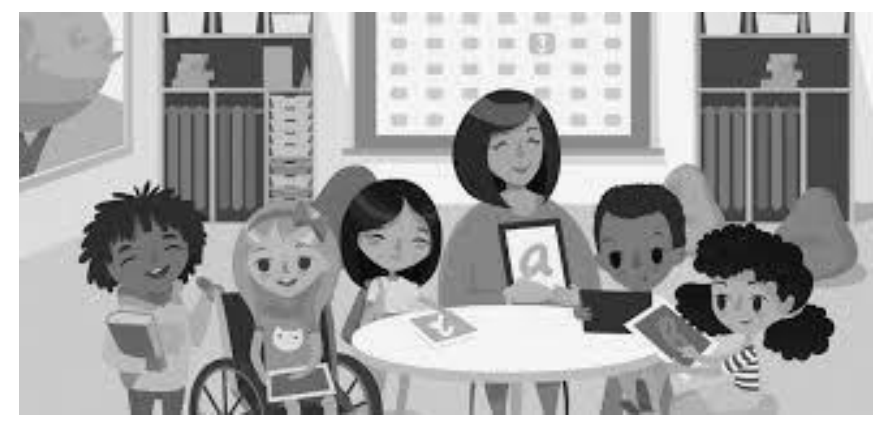

No brasil apenas $26 \%$ das escolas públicas são acessíveis a alunos com deficência, sendo algumas que não possuem todos os materiais necessários para uma educação completa e inclusiva. A maioria das escolas de hoje em dia procuram um meio de incluir todos os alunos ,porém muitas não conseguem cumprir esta tarefa ,pois não possuem recursos finânceiro para novos equipamentos e educadores especializados na ajuda a essas crianças.

Além dos muitos desafios, a inclusão não depende apenas da escola estar preparada com equipamentos ou não estar, uma escola inclusiva é algo feito em conjunto e é necessário um colaboração entre alunos, os profesores os páis etc. "visto que muitas vezes nós professores temos dificuldade em trabalhar com esses alunos em relação as limitações de cada um, não temos a preparação certa para lidar com os mesmos. Já os outros alunos, acredito que acolhem bem os alunos de inclusão, acho que isso acontece de forma bem bacana e legal, mas algumas vezes os próprios alunos portadores de necessidades especiais, se retraem um pouco e não deixam os outros se aproximarem " Opina a professora Ana Caroline que trabalha na Escola Estadual Engenheiro henrique Dumont ,que tenta ao máximo ser inclusiva a alunos con deficiências físicas e mentais.

Veja mais sobre em :https://gestaoescolar.org.br/conteudo/1972/desafios-na-inclusao-dosalunos-com-deficiencia-na-escolapublica\#: :text=O\%20aluno $\% 20$ com $\% 20$ defici $\%$ C3\%AAncia $\% 20$ tem,oferece $\% 20$ assist $\% \mathrm{C} 3$ $\%$ AAncia $\% 20 t \%$ C3\%A9cnica $\% 20 \mathrm{e} \% 20$ financeira. 
Muitas escolas tentam reproduzir a inclusão porém a inclusão dentro de uma escola pública pode ser bem difícil ,muitas escolas possuem sonhos com equipamentos necessários para a educação das crianças na escola ,porém estes sonhos estão bem distantes da nossa realidade ,a maioria das escolas públicas possuem dificuladades em até mesmo salas comuns para a aprendizagem. Boa parte dessa dificuldade vem da falta de fundos finaceiros que são recebidos do governo que poucas vezes investem em cauzas como essas onde é necessários para facilitar o dia a dia destas crianças.

Os equipamentos necessários são bem caros como as carteiras adaptadas, as placas em braili ,os corrimoes nas paredes, etc ,mas a dificuldade que mais ocorre é a falta de uma professor de apoio ,muitos alunos com deficiências metais necessitam de um professor dentro da sala de aula que o acompanhe e o ajude nas atividades em geral, além de interpretes em libras para surdos e mudos além de vários outros tipos de professores com estes exemplos. A maior complicação de ter um professor de apoio ou um interprete em uma sala de aula ,são as coisas necessárias para o requerimento de algum deles ,no brasil muitas escolas necessitam de um laudo médico do aluno para poderem requistar um destes professores que na opinião de muitos é algo muito desnecessário pois, uma escola deveria obrigatoriamente ter ao menos um destes educadores contratados mas, apenas alunos com estes laudos podem requisitar um deste educadores ou seja muitos alunos que nao possuem condiçao de ir a um medico particular para conseguirem estes laudos não conseguem ser incluidos nas salas de aula ,oque atrapalha ainda mais a inclusão em escolas públicas

Apesar de algumas escolas serem iclusivas esse tema é muito pouco abordado nas escolas mais pobres ou menos informadas, este tema é muito importante ser abordado para que um dia estas crianças possam viver em um munso onde elas tambem importam igualmentes as outras crianças " A inclusão escolar vem aos poucos ganhando espaço, mas ainda existe um pouco do despreparo do sistema regular. O que eu quero dizer com isso? É que há resistência de algumas escolas principalmente no âmbito privado na aceitação desses alunos com deficiência então isto precisa ser mudado, precisa ter uma outra roupagem para que essas crianças e adolescentes sejam aceitos e realmente se faça a inclusão, que a inclusão saia do papel " Diz a Psicopedagoga Adriana Lamas .Apesar das dificuldades que estas escolas passam para conseguirem incluirem os alunos com deficiencia ,no futuro proximo muito mais escolas iram se tornar inclusiva tornando o mundo mais inclusivo e um mundo amigo. 
Veja mais sobre em https://www.pedagogia.com.br/artigos/asdificuldadesdainclusao/\#: :text=As\%20dificuldades $\% 20$ encontradas $\% 20$ para $\% 20$ a,familiar $\% 20$ para $\% 20$ com $\% 20$ essas $\% 20$ crian $\%$ C $3 \%$ A 7 as. 


\section{Alunos portadores de necessidades especiais em período de pandemia}

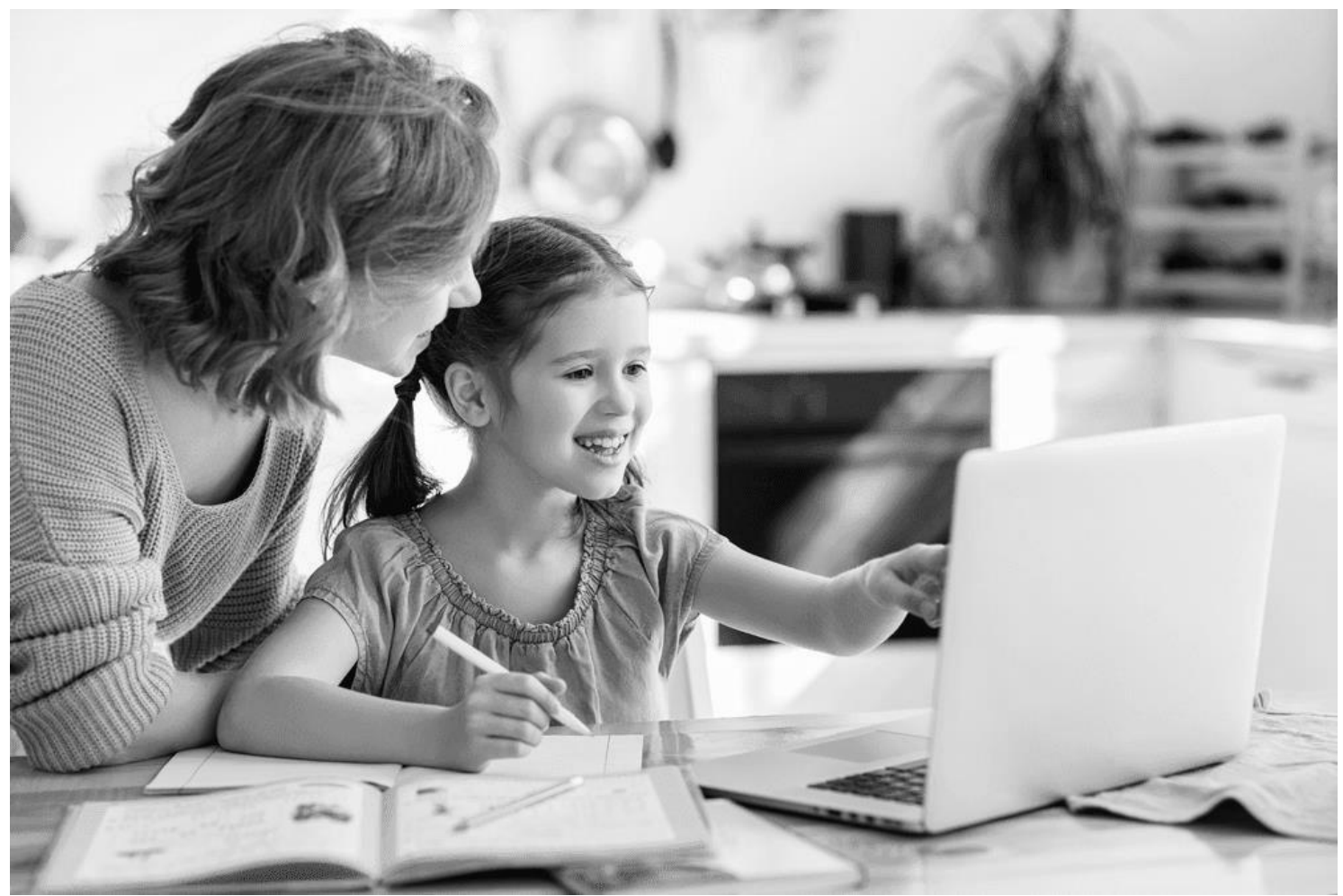

Quando a pandemia do novo coronavírus se agravou em meados de março, as escolas fecharam e os educadores tiveram de se reinventar para garantir que todos os alunos tivessem acesso à Educação. Com isso veio muitos desafios, estudantes sem conexão com a internet e desmotivados, dificuldades para apresentar aulas online, dúvidas sobre como engajar e avaliar a turma, entre outros.

Com os alunos com necessidades especiais a dificuldade é ainda maior, é preciso pensar em uma forma eficiente para se comunicar com os alunos a distância, fazer com que as atividades cheguem aos alunos, pensar em formas para que os mesmos não fiquem desmotivados, formas para que os pais ou responsáveis consigam aplicar as atividades de forma fácil, dinâmica e proveitosa, entre outras coisas muito importantes.

É preciso considerar que os alunos são diferentes entre si, ainda que tenham a mesma deficiência, por exemplo. É essencial que o aprendizado desses alunos seja pensado de forma única, pois cada um tem suas dificuldades, suas potencialidades, suas necessidades, cada um tem sua forma de aprender... Então é necessário um ensino especial, individual e muito bem 
estruturado para que possa atender da melhor forma os alunos. Por mais que a interlocução com a família ou a presença de profissionais de apoio sejam importantes, não podemos deixar de ouvir o próprio aluno e dar a ele a oportunidade de mostrar a melhor forma de atendê-lo, e de que maneira ele se sente mais confortável.

A professora de inglês na Escola Estadual Engenheiro Henrique Dumont (Polivalente), Ana Caroline de Meireles Silva, ou como muitos a conhecem, Teacher Carol, afirma que: "Essa é uma questão difícil, dado que nós estamos tendo uma certa difículdade para atingir e contactar os alunos de um modo geral. Em nossa escola são as professoras de apoio, que estão entrando em contato com os alunos portadores de necessidades especiais, pois elas têm uma maior proximidade com eles. Geralmente elas passam as atividades para os responsáveis, que tentam fazer com os alunos. O ensino remoto fica muito limitado, as alternativas que nós temos é por ferramentas como o WhatsApp, vídeo chamadas, enfim, não vejo outras alternativas no momento!"

Geralmente os alunos precisam de um grande apoio para realizar as atividades, e é aí que está umas das maiores dificuldades. Muitas vezes, os pais, responsáveis ou quem poderia ajudar, trabalha, não tem tempo, não tem o preparo necessário para aplicar de maneira correta e proveitosa as atividades propostas pelas escolas, e infelizmente, as vezes acontece de os familiares não estarem interessados a dar essa atenção especial aos alunos.

É grande a importância da interlocução, do alinhamento e do trabalho colaborativo dos professores deste atendimento com os professores da sala comum e com a coordenação pedagógica. A relação entre o trio deve ser mantida e fortalecida para que os profissionais de AEE apoiem os profissionais de sala comum no que diz respeito à criação de recursos pedagógicos acessíveis e ao planejamento de atividades inclusivas para toda a turma. Existem muitos benefícios quando o trabalho conjunto entre esses profissionais é feito, pois a parceria agrega qualidade à proposta pedagógica não só para os estudantes com deficiência como para toda a classe.

Saiba mais sobre o ensino a distância para alunos portadores de necessidades especiais em: https://novaescola.org.br/conteudo/19694/12-respostas-sobre-educacao-inclusiva-em-temposde-pandemia 